\title{
LUDWIK DE FLEURY I WCZESNOŚREDNIOWIECZNE CMENTARZYSKA Z GROBAMI W OBUDOWACH KAMIENNYCH NA WYSOCZYŹNIE KOLNEŃSKIEJ ${ }^{1}$
}

\begin{abstract}
Abstrakt: W 1892 r. Louis de Fleury, amator poszukiwań archeologicznych, skierował swe zainteresowania na cmentarzyska $\mathrm{z}$ grobami w obudowach kamiennych na północno-wschodnim Mazowszu. Na kilku z nich rozkopał łącznie około 20 grobów. Sprawozdanie z prac przekazał do Cesarskiej Komisji Archeologicznej w Petersburgu. W ciągu kolejnych kilkudziesięciu lat cmentarzyska te uległy praktycznie całkowitemu zniszczeniu. Tym samym, rezultaty prac L. de Fleury’ego pozostały głównym źródłem informacji o tych nekropolach, a więc i o zwyczajach pogrzebowych ludności zamieszkującej owo pogranicze Polski, ludów pruskich i Rusi w XI-XII w. W ciągu blisko 130 lat od czasu jego rozkopywań, w literaturze archeologicznej pojawiały się tylko niepełne i często mylne wiadomości na ich temat. Niniejsza publikacja jest pierwszą, w której szczegółowo omówiono wyniki prac L. de Fleury’ego oraz ich znaczenie dla poznania procesów osadniczych na Wysoczyźnie Kolneńskiej w 2 poł. XI w. i 1 poł. XII w.
\end{abstract}

Słowa kluczowe: Louis de Fleury, Wysoczyzna Kolneńska, Kokoszki, Kotówek, Ruś, Pieńki-Okopne, pogranicze polsko-ruskie, archeologia migracji, groby w obudowach kamiennych, wczesne średniowiecze

\begin{abstract}
In 1892, amateur archaeologist Louis de Fleury became interested in cemetery sites with graves of stone structure located in northeastern Masovia, where he excavated about 20 graves in different localities. A report from this work was presented to the Imperial Archaeological Commission in Petersburg. The sites in question were nearly all destroyed in the next few dozen years making de Fleury's work the sole source of data on these burial grounds and by the same also on the burial customs of the people living in the $11^{\text {th }}-12^{\text {th }}$ centuries in this borderland, Prussian on one hand and Rus' on the other. Very little of this material has been published over the 130 years since de Fleury's time and much of it is incomplete and often erroneous. This in-depth study of de Fleury's results demonstrates their significance for understanding settlement processes in the Kolno Upland in the second half of the $11^{\text {th }}$ and the first half of the $12^{\text {th }} \mathrm{c}$.
\end{abstract}

Keywords: Louis de Fleury, Kolno Upland, Kokoszki, Kotówek, Ruś, Pieńki-Okopne, Polish-Rus' borderland, migration archaeology, stone-structure graves, early medieval period

${ }^{a}$ Dr Michał Dzik, Instytut Archeologii, Uniwersytet Rzeszowski, ul. S. Moniuszki 10, 35-015 Rzeszów, mdzik@ur.edu.pl, ORCID ID: https://orcid.org/0000-0003-1584-4452.

1 Autor składa serdeczne podziękowania prof. Aleksandrowi Musinowi z Instytutu Historii Kultury Materialnej Rosyjskiej Akademii Nauk, dzięki którego pomocy na różnych etapach pracy powstał niniejszy artykuł. 


\section{WSTĘP}

Nurtem badawczym charakterystycznym dla archeologii na obecnym etapie jej rozwoju jest weryfikacja stanu wiedzy na podstawie pozyskanych niegdyś materialów archeologicznych. Ważną rolę $\mathrm{w}$ tym procesie odgrywa ponowna ocena wyników dawnych badań wykopaliskowych oraz poszukiwanie materiałów archiwalnych i zabytkowych, które nie zostały w pełni wykorzystane w badaniach naukowych. W tym kontekście dla polskiej archeologii niemałą rolę mogą odegrać materiały archiwum Cesarskiej Komisji Archeologicznej (dalej: CKA).

CKA powołano w Petersburgu, 2 lutego 1859 r. Jej zadaniem była kontrola nad znaleziskami skarbów i ich nabywanie, prowadzenie wykopalisk archeologicznych i opracowywanie zabytków, od samego początku była też zaangażowana w ochronę dziedzictwa kulturowego. Komisja była jedynym organem państwowym, który wydawał pozwolenia na prowadzenie badań wykopaliskowych w Rosji i Królestwie Polskim. Zgodnie z regulaminem, wymagała sprawozdań z badań, a w niektórych przypadkach przysyłania odkrytych zabytków.

W 2 poł. XIX w. i na początku kolejnego stulecia polscy uczeni woleli współpracować z Moskiewskim Towarzystwem Archeologicznym, które uznawano za bardziej demokratyczne, mimo że pomijanie CKA było sprzeczne z ustawodawstwem Imperium Rosyjskiego (Blombergowa 1988, s. 62 nn.; taż 1989; 1993)2. Tym niemniej, dzięki systematycznemu tworzeniu archiwum CKA zgromadziło bogaty materiał rękopiśmienny i fotograficzny dotyczący archeologii i kultury ziem dawnej Rzeczypospolitej. Jedynie częściowo został on opublikowany w wydawanych przez Komisję „Sprawozdaniach” (Otčët Imperatorskoj Archeologičeskoj Komissii, 1859-1918) ${ }^{3}$ i „Wiadomościach” (Izvestiâ Imperatorskoj Archeologičeskoj Komissii, 1901-1918).

W 1919 r. Komisja, która w tamtym czasie nosiła nazwę Rosyjskiej Państwowej Komisji Archeologicznej, została przekształcona w Akademię Historii Kultury Materialnej, która dała początek instytutom archeologicznym współczesnej Rosji (por. Musin, Nosov red. 2009; Szczerba 2010; taż 2012; Musin, Medvedeva red. 2019).

Archiwum CKA, przechowywane w Instytucie Historii Kultury Materialnej Rosyjskiej Akademii Nauk (Institut Istorii Material'noj Kul'tury; dalej: IIMK RAN) w Petersburgu, jest coraz częściej i owocniej wykorzystywane w badaniach polskich archeologów (np. Buko 2009; Buko red. 2019; Dzik 2015; [2012] 2016). Obecnie stanowi ono główne źródło wiedzy m.in. o działalności na polu archeologii hrabiego

${ }^{2}$ Według M. Blombergowej (1988, s. 62), „Moskiewskie Towarzystwo Archeologiczne uzyskało dla siebie i swoich członków swobodę w organizowaniu wykopalisk ...”. Przeciwnie, zgodnie z porozumieniem między CKA a Moskiewskim Towarzystwem Archeologicznym zawartym w 1889 r., prowadzenie badań archeologicznych przez to ostatnie wymagało zgody Komisji (Musin, Nosov red. 2009, s. 119-122; por. Musin, Medvedeva red. 2019, 1, s. 194-200).

${ }^{3}$ Do 1906 r. wydawane także w języku francuskim, pt. „Compte-rendu de la Commission Impériale Archéologique". 
Louisa de Fleury’ego, prowadzonej na przełomie lat osiemdziesiątych i dziewięćdziesiątych XIX w., a skoncentrowanej w dorzeczu Narwi i Biebrzy ${ }^{4}$.

\section{LOUIS DE FLEURY I WYBRANE ASPEKTY JEGO DZIAŁALNOŚCI ARCHEOLOGICZNEJ}

Louis Eugène de Fleury urodził się w Ruffec, departament Charente we Francji, 3 września 1828 r. $^{5}$ Zdobył wykształcenie prawnicze. Najpóźniej w 1850 r. trafił na dwór hrabiego Jana Alojzego Potockiego. W tym samy roku ożenił się z jego córką, Joanną Potocką (ur. 1822 r.). Po jej śmierci (14 lutego 1870 r.) i podziale spadku, w 1876 r. otrzymał m.in. Kępę Giełczyńską - majątek położony w widłach Narwi i Biebrzy, w którym osiadł na ponad 20 lat. Pół roku po śmierci Joanny ożenił się z Jadwigą Moniuszko (1853-1920). Dwór w Kępie był odwiedzany przez znanych przedstawicieli polskiej kultury, m.in. Zygmunta Glogera, Zygmunta Federowskiego, Kazimierza Waliszewskiego oraz Marię Skłodowską. Po 1898 r. majątek Kępa, w wyniku finansowych problemów właścicieli, został zlicytowany, a L. de Fleury przeniósł się z żoną na krótko do Białegostoku, następnie do Francji, gdzie zmarł w Le Vieux-Cérier, dep. Charente, 24 listopada 1909 r.

Choć działania L. de Fleury’ego na polu archeologii zarówno we Francji, jak i na ziemiach polskich miały charakter amatorski, część z jego ustaleń i opinii znalazła uznanie w środowisku naukowym (por. Notice 1910, s. LXIII nn.). Jego kolekcja zabytków, zebrana w rezultacie wykopalisk oraz prospekcji terenowych, uważana była za jedną z ważniejszych w gub. łomżyńskiej (Volter 1889). L. de Fleury od 1886 r. należał do Towarzystwa Archeologicznego i Historycznego Charente ( $\mathrm{La}$ Société archéologique et historique de la Charente; État... 1892, s. XIV), a od 1890 r. także do paryskiego Towarzystwa Narodowego Starożytników Francji (La Société Nationale des Antiquaires de France; Liste... 1895, s. 33). Pierwsze z nich reprezentował na VIII Zjeździe Archeologicznym w Moskwie, 8-24 stycznia 1890 r., po którym został wybrany członkiem-korespondentem Cesarskiego Moskiewskiego Towarzystwa Archeologicznego (Uvarova, Borozdin red. 1915, s. 393; Blombergowa 1988, s. 73).

Na wspomnianym Zjeździe L. de Fleury wygłosił dwa referaty, poświęcone grodziskom w dorzeczu Narwi oraz neolitycznym wyrobom krzemiennym odkrytym w Kępie (Procès-verbaux [1890-1891] 1892, s. XXVI-XXVII, XLVI, LX-LXI; Protokoly 1897b, s. 86, 168; por. Blombergowa 1986, s. 25) ${ }^{6}$.

${ }^{4}$ Autor dziękuje Dyrekcji IIMK RAN za udostępnienie materiałów archiwalnych będących podstawą niniejszego tekstu.

${ }^{5}$ Dane biograficzne na podstawie publikacji: Notice 1910; Ramotowski 2013; Marczak 2015.

${ }^{6}$ L. de Fleury dodał do jednej ze swych publikacji, choć poświęconej innemu zagadnieniu, ilustracje związane z wykładami z VIII Zjazdu Archeologicznego w Moskwie, tj. pięć drzeworytów z wyobrażeniami następujących stanowisk: kurhanów pod Uśnikiem, pow. łomżyński, oraz grodzisk w Tykocinie, pow. białostocki, Wnorach-Wypychach, pow. wysokomazowiecki, Wiźnie i Samborach (Rusi), pow. łomżyński (Fleury 1894, pl. I-V; w niniejszym tekście określenia powiatów odpowiadają 
Przypuszczalnie podczas pobytu w Moskwie L. de Fleury dowiedział się, iż do prowadzenia prac wykopaliskowych i poszukiwawczych potrzebne jest specjalne pozwolenie CKA. Wiadomo, że prezes CKA, hr. Aleksiej Bobrinskij ${ }^{7}$, osobiście uczestniczył w otwarciu moskiewskiego Zjazdu w styczniu 1890 r. (Musin, Nosov red. 2009, s. 141). Niewykluczone, że to do niego wystąpił wówczas L. de Fleury z prośbą o przekazanie mu zezwolenia, co tłumaczyłoby brak w archiwum CKA pisma w tej sprawie.

Już 7 kwietnia (26 marca) ${ }^{8} 1890$ r. CKA wydała L. de Fleury’emu pozwolenie (nr 313; w języku rosyjskiej biurokracji określane jako Otkrytyj list), na prowadzenie wykopalisk archeologicznych w guberni łomżyńskiej w 1890 r., na ziemiach „państwowych, publicznych i należących do różnych instytucji”" . Dokument został przysłany pocztą do Łomży wraz z pismem przewodnim (Rukopisnyj otdel Naučnogo arhiva IIMK RAN, dalej: RONA IIMK, zb. 1, 1-1890/28, k. 1, 2, 15-15 $\left.\mathrm{r}^{10}\right)$. O jego wydaniu przedstawiciel Komisji, hr. A. Bobrinskij poinformował gubernatora łomżyńskiego (RONA IIMK, zb. 1, 1-1890/28, k. 3; funkcję tę pełnił wówczas Reinhold Roman von Essen).

W pozwoleniu wskazano, że kierownik wykopalisk jest zobowiązany dostarczyć do CKA sprawozdanie lub dziennik terenowy z opisem wszystkich znalezisk, a także przysłać najcenniejsze i najciekawsze przedmioty do Petersburga w celu zaprezentowania ich cesarzowi.

Pomimo otrzymanego dokumentu, ani w 1890, ani w kolejnym roku L. de Fleury nie przeprowadził wykopalisk. Przyczyny tego nie są znane. Dopiero w 1892 r., a więc półtora roku po wygaśnięciu oficjalnego pozwolenia, podjął prace na trzech opisanych niżej nekropolach.

L. de Fleury zorganizował badania na cmentarzyskach w dniach 18-27 czerwca i 1 sierpnia 1892 r. (RONA IIMK, zb. 1, 1-1890/28, k. 5-9r). 3 stycznia 1893 r. przesłał do Petersburga: raport w języku francuskim zawierający rysunki wybranych zabytków, grobów i czaszek; nieaktualne pozwolenie na prowadzenie badań (na 1890 r.) oraz list przewodni zawierający m.in. prośbę o wydanie kolejnego pozwolenia (RONA IIMK, zb. 1, 1-1890/28, k. 4-4r). Raport wpłynął 13(1) marca, a został rozpatrzony na posiedzeniu Komisji 22(10) marca. Do dokumentów L. de Fleury nie dołączył zabytków, co wytłumaczył niewielką ich wartością oraz ryzykiem uszkodzenia w drodze. Wyraził jednak gotowość ich wysłania w razie konieczno-

aktualnym, o ile nie zaznaczono inaczej). Kurhany pochodzą z okresu wpływów rzymskich (Cieśliński 2014, s. 52 nn.), zaś grodziska z wczesnego średniowiecza (Ościłowski 2011, s. 24, 25, 28, 30 - tam starsza literatura). Ilustracje wykonał warszawski drzeworytnik Jan Styfi (Kotańska 1997, s. 100 passim), na podstawie rysunków samego L. de Fleury’ego.

${ }^{7}$ Pierwotną formą nazwiska hrabiego jest Bobrinskoj, jednak w radzieckiej i rosyjskiej literaturze archeologicznej powszechnie przyjęty jest zapis w formie Bobrinskij.

${ }^{8} \mathrm{~W}$ opisie dokumentów datowanych według kalendarza juliańskiego, w pierwszej kolejności podano datę gregoriańską, następnie - $\mathrm{w}$ nawiasie - zapisaną $\mathrm{w}$ dokumencie.

${ }^{9}$ Podane w artykule w języku polskim fragmenty dokumentacji archiwalnej spisanej po rosyjsku zostały przetłumaczone przez autora.

${ }^{10}$ Skróty zb. oraz k. oznaczają zbiór oraz kartę. Zgodnie z zasadami zapisu archiwum naukowego IIMK, sygnaturę zb. 1, 1-1890/28 należy rozwinąć jako: fond 1, opis’ 1, 1890 god, dělo 28. 
ści. Zwrócił się również o zwrot rękopisu raportu z uwagami CKA - zaznaczając, iż nie jest on jeszcze kompletny.

1 kwietnia (20 marca) 1893 r. hr. A. Bobrinskij wysłał list do L. de Fleury’ego, informując go o wydaniu nowego pozwolenia na prowadzenie wykopalisk, na 1893 r. (RONA IIMK, zb. 1, 1-1890/28, k. 16, 17-17r). Przewodniczący potwierdził odesłanie raportu de Fleury, dziękując mu osobno za przesłane rysunki.

L. de Fleury kolejnych badań już jednak nie przeprowadził. 4 października (22 września) 1894 r. Wasilij Drużynin, sekretarz naukowy kancelarii CKA, wysłał hrabiemu pismo z prośbą o przesłanie Komisji rysunków lub fotografii jednego $\mathrm{z}$ grobów, które rozkopał, $\mathrm{z}$ pozwoleniem ich opublikowania $\mathrm{w}$ jednym $\mathrm{z}$ wydawnictw CKA. Oryginały tej dokumentacji Komisja zobowiązywała się odesłać hrabiemu.

Żadna odpowiedź na ten list nie zachowała się w archiwach, jednak najwyraźniej potrzebne materiały zostały przekazane do Petersburga. 23(11) marca $1895 \mathrm{r}$. Komisja wysłała hrabiemu kolejne pismo z informacją, że odsyła mu teczkę z fotografiami różnych przedmiotów z guberni grodzieńskiej i łomżyńskiej, dodając, że CKA była szczególnie zainteresowana fotografiami nr 31-42. Jednocześnie zwrócono się o przysłanie dwóch rysunków cmentarzyska przy Małych Rostkach, wykonanych piórem (RONA IIMK, zb. 1, 1-1890/28, k. 19). Pismo to pozostało już bez odpowiedzi.

Informacje na temat swych prac L. de Fleury szybko udostępnił środowisku naukowemu, bowiem referat im poświęcony wygłosił już 16 sierpnia 1892 r. na Międzynarodowym Kongresie Archeologii i Antropologii Prehistorycznej w Moskwie. Tekst wystąpienia ukazał się drukiem rok później i jest najszerszą publikacją wyników interesujących nas badań (Fleury 1893). W 1893 r. rezultaty swych rozkopywań de Fleury przedstawił na IX Zjeździe Archeologicznym w Wilnie. Opublikowane zostały krótkie wiadomości o wykładzie i jego streszczenia (Protokol" 1893, s. 4; Zasědanie 1893, s. 366-367; Smorodskij 1893, s. 26; Żytyński 1893, szp. 124; Storožev 1894, s. 10; Protokoly 1897a, s. 99).

Wybrane zabytki z badań na cmentarzyskach lub ich ilustracje L. de Fleury zabrał na konferencję w Moskwie, gdzie konsultował je $\mathrm{z}$ archeologiem Władimirem I. Syzowem (Fleury 1893, s. 334). Na pewno znaleziska zawiózł do Wilna, gdzie jego kolekcja była prezentowana ${ }^{11}$. Możliwe, że przedmioty te trafiły również na wystawę czasową sztuk pięknych w Łomży, we wrześniu 1898 r., na której udostępnił bliżej nieopisane „wykopaliska” ze swoich zbiorów (Katalog 1898, s. 17, poz. 44). Dalszy los kolekcji archeologicznej L. de Fleury’ego z badań na cmentarzyskach nie jest znany ${ }^{12}$.

${ }^{11}$ Jego zbiór nie został wymieniony w katalogu przedmiotów, które trafiły na wystawę IX Zjazdu Archeologicznego (Katalog 1893), jednak informacja o ich wystawieniu znalazła się w protokole z jednego z posiedzeń zjazdu (Zasědanie 1893, s. 305) oraz w wiadomościach gazetowych (Zjazd 1893, s. [4]).

12 Wbrew powtarzanym w literaturze przedmiotu informacjom (np. Rauhut 1971, s. 618, poz. 133; Burek 1977, s. 38; Blombergowa 1988, s. 74; Kowalczyk-Heyman 2007a, s. 297; taż 2013, s. 191), brak jest dowodów na to, by zabytki z badań wykopaliskowych L. de Fleury’ego trafiły do Ermitażu. Nie ma ich w zbiorach petersburskiego muzeum, ani też w Państwowym Muzeum Historycznym w Moskwie, dokąd CKA wysyłała zwykle zabytki archeologiczne z badań na cmentarzyskach średniowiecznych. 
Dla upowszechnienia wiedzy o wynikach badań L. de Fleury’ego większe znaczenie niż jego artykuł - nieznany polskim badaczom - miała publikacja Aleksandra Spicyna z 1925 r. Przy okazji omawiania grobów z konstrukcjami kamiennymi sumarycznie opisał on rezultaty prac Francuza (Spicyn 1925, s. 158). W swym artykule A. Spicyn nie podał źródła informacji. Zważywszy jednak, że wymienił lokalizacje cmentarzysk, które znalazły się w publikacji L. de Fleury’ego (1893), ale nie w jego archiwalnym sprawozdaniu, niewątpliwie opierał swoje wiadomości na owym artykule (potwierdza to zresztą jego odręczna notatka - ryc. 1a). A. Spicyn był członkiem CKA od lutego 1892 r., stąd mógł znać także materiały znajdujące się w posiadaniu Komisji, w tym niezachowane do chwili obecnej. Niewykluczone też, że uczestniczył w posiedzeniu CKA 22(10) marca 1893 r., na którym przyjęto raport L. de Fleury'ego. Na dostęp do nieznanych obecnie materiałów wskazuje zresztą fakt, iż, opisując wygląd grobów, Spicyn powołał się na rysunek przedstawiający jedną z mogił (Spicyn 1925, s. 158). Takie rysunki były dołączone do oryginału sprawozdania de Fleury'ego, ale obecnie brak ich w archiwum IIMK RAN, nie zostały też opublikowane. Potwierdzeniem korzystania przez rosyjskiego uczonego z oryginału raportu L. de Fleury'ego lub innej, obecnie niezachowanej dokumentacji, są notatki $\mathrm{z}$ archiwum prywatnego A. Spicyna (por. niżej).

Informację o wykopaliskach de Fleury'ego oraz opis ich wyników za A. Spicynem przytoczył Aleksander Kamiński (1956, s. 221; tenże 1961, s. 43), a za nim kolejni autorzy (np. Rauhut 1971, s. 616-619, poz. 127-134; Ramotowski 2013). Bardziej szczegółowe wiadomości o wynikach badań w 1892 r. na cmentarzyskach w Kokoszkach i Rostkach Małych opublikował Lechosław Rauhut (1971, s. 617-618, poz. 130, 133). Źródłem jego wiedzy były notatki Jerzego Okulicza-Kozaryna, sporządzone podczas kwerendy w archiwum IIMK RAN w Leningradzie w 1958 r. Mankamentem opisów podanych przez L. Rauhuta są pomyłki w określeniu niektórych zabytków, ale i stanowisk, jak na przykład wiadomość o rzekomym cmentarzysku w Jedwabnie, jakoby badanym przez L. de Fleury’ego (Rauhut 1971, s. 616-617; tak też Miśkiewiczowa 1982, s. 183; na ten temat por. Kowalczyk-Heyman 2007a). W opracowaniu L. Rauhuta zabrakło jakichkolwiek wiadomości o wykopaliskach w Rusi, a samo cmentarzysko zostało wymienione jako zbadane przez L. de Fleury’ego wyłącznie powierzchniowo.

\section{SPRAWOZDANIE L. DE FLEURY'EGO Z BADAŃ CMENTARZYSK WCZESNOŚREDNIOWIECZNYCH}

Obecnie głównym źródłem wiedzy o badaniach L. de Fleury’ego na interesujących nas nekropolach są materiały przechowywane $\mathrm{w}$ archiwum IIMK RAN. W teczce poświęconej jego wykopaliskom znajduje się 21 kart dokumentów datowanych od 5 kwietnia (24 marca) 1890 r. do 23(11) marca 1895 r., w tym pozwolenia na prowadzenie badań oraz korespondencja L. de Fleury’ego z CKA (RONA IIMK, zb. 1, 1-1890/28).

Największą wartość ma tłumaczenie na język rosyjski spisanego po francusku sprawozdania L. de Fleury’ego z rozkopywań w 1892 r. (RONA IIMK, zb. 1, 


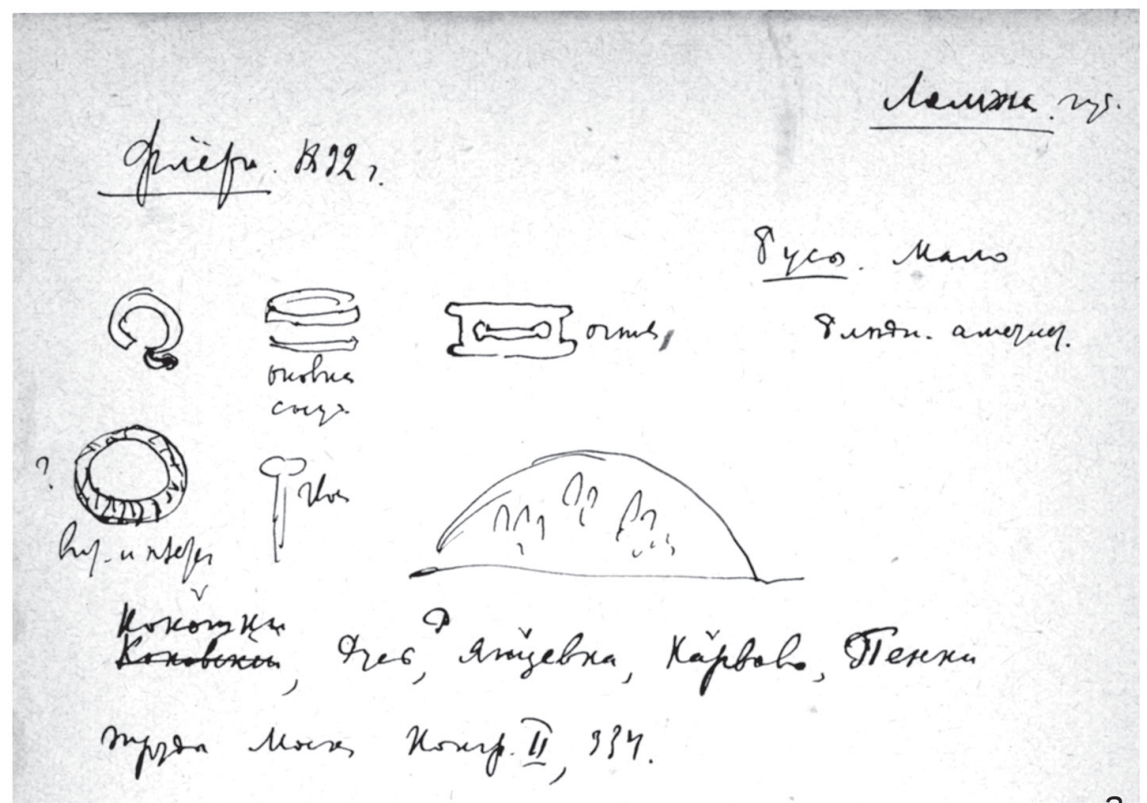

a

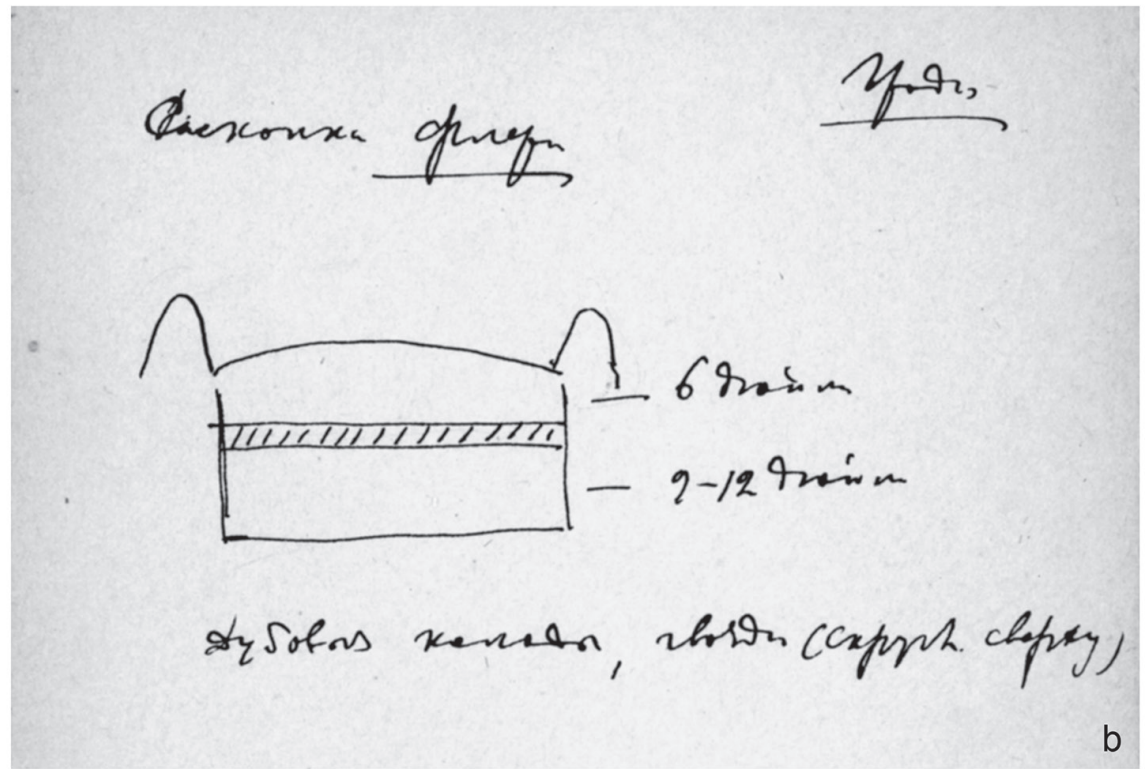

Ryc. 1. Notatki z archiwum prywatnego A. Spicyna dotyczące badań L. de Fleury’ego.

Wg RONA IIMK, zb. 5, sygn. 372, k. 280, 281; opracował M. Dzik

Fig. 1. Notes from the private archive of A. Spicyn concerning the investigations of Louis de Fleury. After RONA IIMK, coll. 5, sign. 372, card 280, 281; processing M. Dzik 
1-1890/28, k. 4a-11r). Sądząc po charakterze pisma, sporządził je wiceprzewodniczący Komisji Władimir Tizengauzen (na jego temat: Musin, Nosov red. 2009, s. 48-50; por. Musin, Medvedeva red. 2019, 1, s. 104-107). Analiza szesnastostronicowego rękopisu nie pozostawia wątpliwości, iż jest on dosłownym przekładem raportu. Przy słowach, które mogłyby być dla czytelnika niejasne lub niejednoznaczne, tłumacz podał $\mathrm{w}$ nawiasach określenia francuskie użyte $\mathrm{w}$ oryginalnym tekście. Odnotował również obecność i treść 17 z 18 rysunków dołączonych do sprawozdania, z których zachowały się tylko trzy akwarelowe tablice z zabytkami (RONA IIMK, zb. 1, 1-1890/28, k. 12-14; ryc. 2-4). Brak pozostałych ilustracji wynika najprawdopodobniej $\mathrm{z}$ włączenia ich bezpośrednio $\mathrm{w}$ tekst oryginału raportu, a ten - jak już wspomniano - odesłano autorowi ${ }^{13}$. Rysunki przedstawiały kolejno: 1. bliżej nieokreślony grób w obudowie kamiennej w trzech postaciach: przed jego rozkopaniem, po usunięciu darni oraz „całkowicie oczyszczony” (wspomniany tamże, k. 5); 2. tablicę z zabytkami z Rostek Małych, z grobu nr 1 (w przekładzie raportu tablica nie jest wymieniona; ryc. 2); 3. czaszkę z tego grobu (tamże, k. 6r); 4. zawieszkę dzwoneczkowatą i osełkę z Rostek Małych, z grobu nr 3 (tamże, k. 6r); 5. zapinkę lub sprzączkę z Rusi, z grobu nr 11 (tamże, k. 7r); 6. tablicę z zabytkami z Rusi, z grobu nr 2 (tamże, k. 8; ryc. 3); 7. czaszkę z Rusi, z grobu nr 2 (tamże, k. 8r); 8. przęślik z Rusi, z grobu nr 3 (tamże, k. 9); 9. czaszkę w trzech rzutach, z Rusi, z grobu nr 12 (tamże, k. 9); 10. grób nr 6 z Rusi (tamże, k. 9); 11. tablicę z zabytkami z grobu nr 6 (tamże, k. 10; ryc. 4); 12. czaszkę w trzech rzutach, z Grodziska w gub. siedleckiej (tamże, k. 10r); 13-18. czaszki sześciu szkieletów z cmentarzyska w Żarnówce, w gub. siedleckiej, z grobów oznaczonych numerami: V, VII, IX, XVII, XIX oraz A (tamże, k. 11-11r).

W tekście L. de Fleury’ego wyróżnić można trzy części. W pierwszej autor opisał wygląd i budowę grobów na stanowiskach, które nazwał „cmentarzami z przegrodami” (les cimetières à compartiments). Zamieścił też uwagi o zasięgu występowania takich nekropoli, odkrywanych według niego od Podlasia - tu powołał się na badania N. Awenariusa ${ }^{14}$ - po Gdańsk i Wielkie Księstwo Poznańskie. Według niego, miano w nich zawsze odkrywać szkielety o dolichocefalicznych czaszkach, a przy nich liczne przedmioty, których listę wymienił. L. de Fleury datował je na X, XI i XII w. Ze względu na „pogańskie” cechy grobów, a także obszar występowania, uznał je za miejsca pochówku Jaćwingów i innych ludów zaliczanych do Prusów.

Następnie autor przeszedł do przedstawienia wyników badań przeprowadzonych przez siebie na trzech cmentarzyskach położonych w: Kokoszkach, Rostkach

${ }^{13}$ Pośrednio to wyjaśnienie potwierdzają szczegóły przekładu, w którym odniesienia do rycin podano w różnych miejscach tekstu, poprzedzając je sformułowaniami „następuje rysunek...”, „następuje wyobrażenie...”.

${ }^{14}$ L. de Fleury gościł N. Awenariusa w Kempie w 1889 r. (RONA IIMK, zb. 1, 1-1889/42, k. 6). Mógł również zapoznać się z rezultatami jego prac m.in. w trakcie archeologicznych zjazdów w Moskwie (1890) i Wilnie (1893), w których obaj wzięli udział. Na pierwszym z nich Awenarius miał wystąpienie poświęcone wykopaliskom na cmentarzyskach z grobami w obudowach kamiennych w okolicy Drohiczyna (Avenarius 1897). Możliwe również, że de Fleury znał niewiele wcześniej wydany artykuł rosyjskiego badacza (Avenarius 1890). 


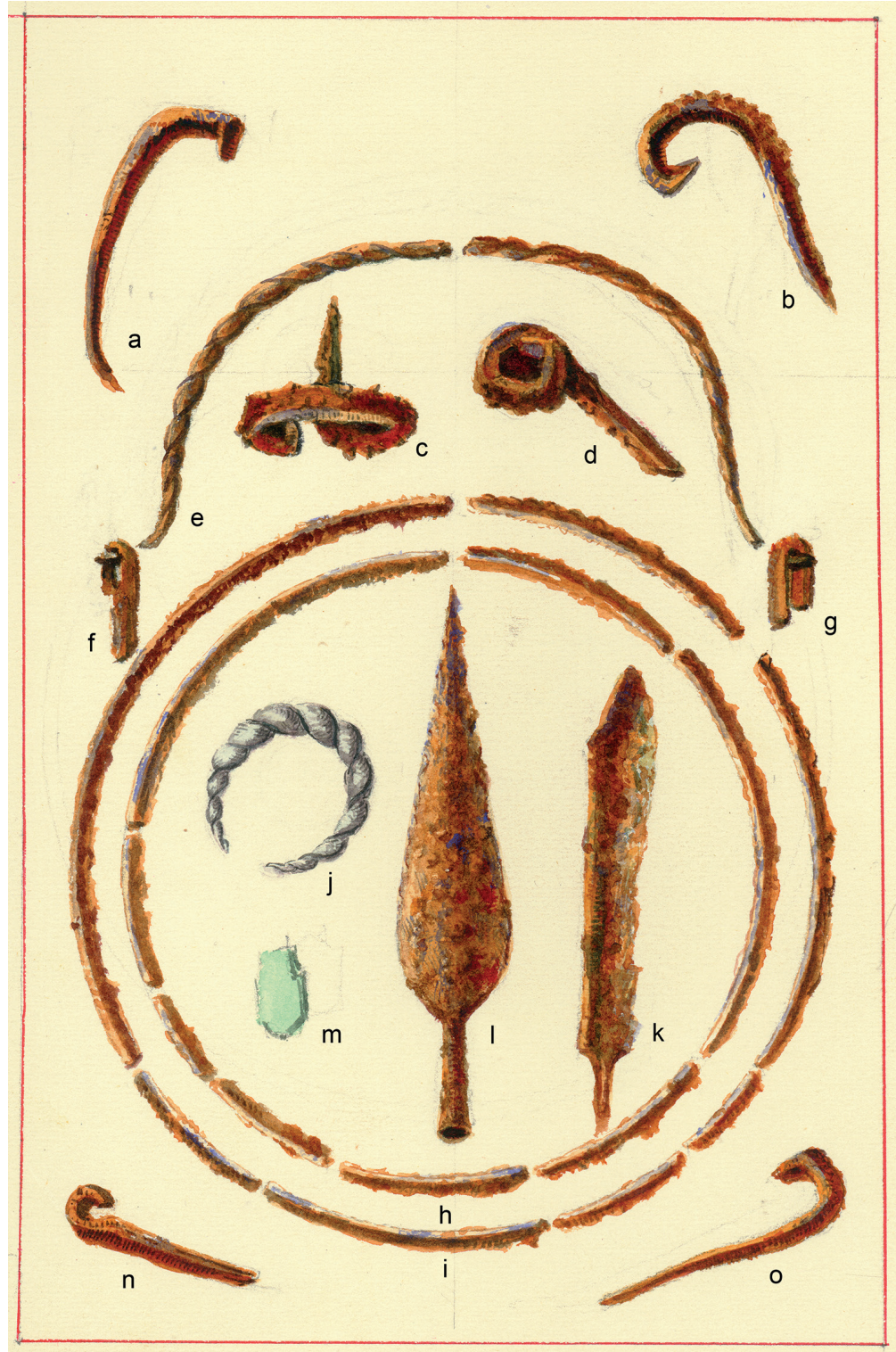

Ryc. 2. Zabytki z rozkopywań L. de Fleury’ego w Kotówku (Rostkach Małych), z grobu nr 1 a-d, n, o - gwoździe; e-i - okucia wiadra klepkowego; $\mathrm{j}$ - pierścień; $\mathrm{k}$ - nóż; 1 - grot broni drzewcowej; $\mathrm{m}$ przedmiot nieokreślony.

Wg RONA IIMK, zb. 1, 1-1890/28, k. 14; opracował M. Dzik

Fig. 2. Finds from de Fleury's excavations in Kotówek (Rostki Małe), grave 1

$\mathrm{a}-\mathrm{d}, \mathrm{n}, \mathrm{o}$ - nails; $\mathrm{e}-\mathrm{i}$ - fittings of a stave bucket; $\mathrm{j}$ - ring; $\mathrm{k}$ - knife; $\mathrm{l}$ - point of a shafted weapon; $\mathrm{m}$ - unidentified object. 


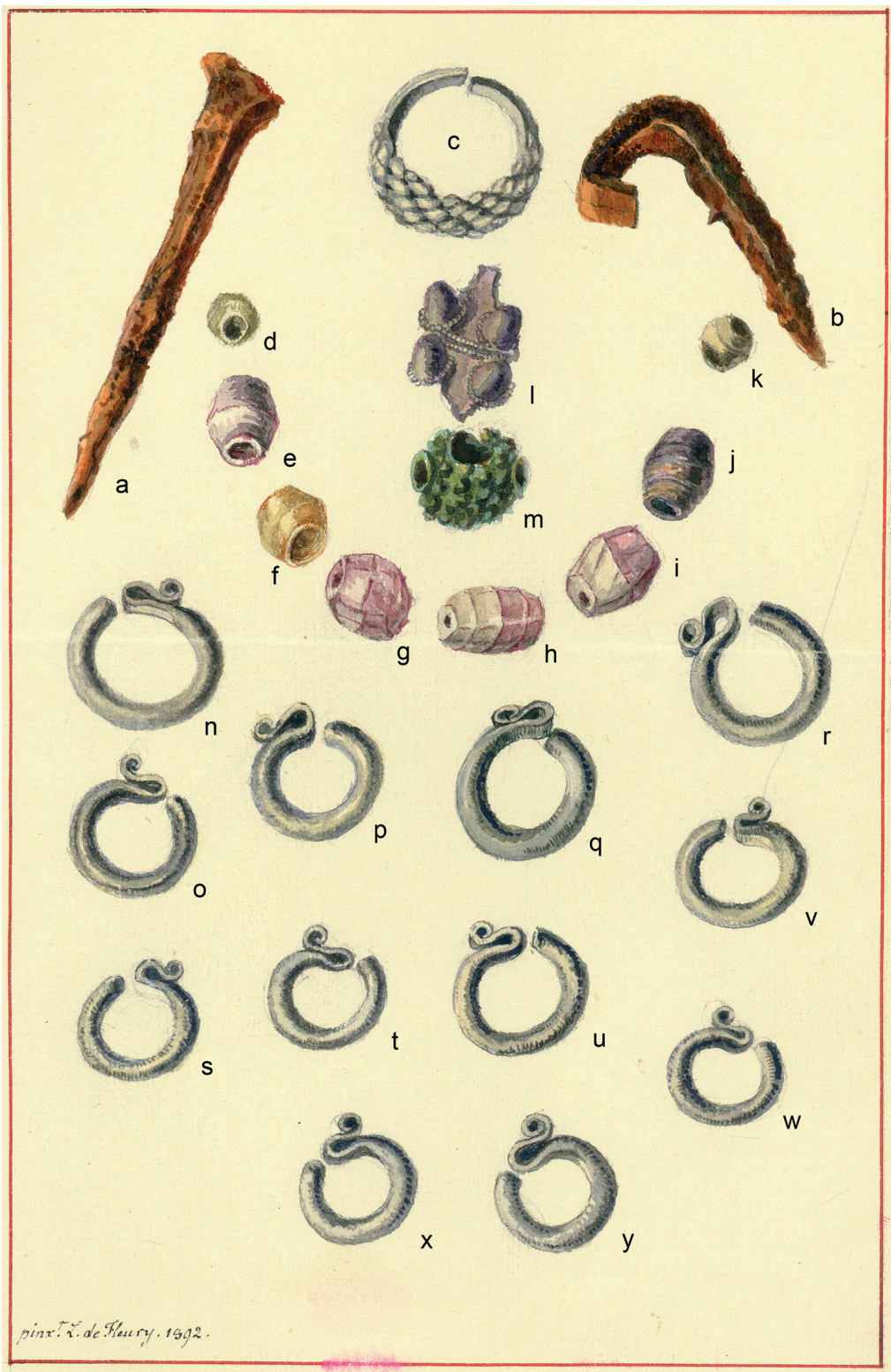

Ryc. 3. Zabytki z rozkopywań L. de Fleury’ego w Rusi, pow. łomżyński, z grobu nr 2 a, b - gwoździe; c - pierścień; d-f, j, k - paciorki szklane; g-i - paciorki kamienne; l, m - paciorki metalowe; $\mathrm{n}-\mathrm{y}$ - kabłączki skroniowe.

Wg RONA IIMK, zb. 1, 1-1890/28, k. 13; opracował M. Dzik

Fig. 3. Finds from de Fleury's excavations in Ruś, Łomża district, grave 2

a, b - nails; c - ring; $\mathrm{d}-\mathrm{f}, \mathrm{j}$, $\mathrm{k}$ - glass beads; $\mathrm{g}-\mathrm{i}$ - stone beads; $\mathrm{l}, \mathrm{m}$ - metal beads; $\mathrm{n}-\mathrm{y}$ - temple rings. After RONA IIMK, coll. 1, 1-1890/28, card 13; processing M. Dzik 


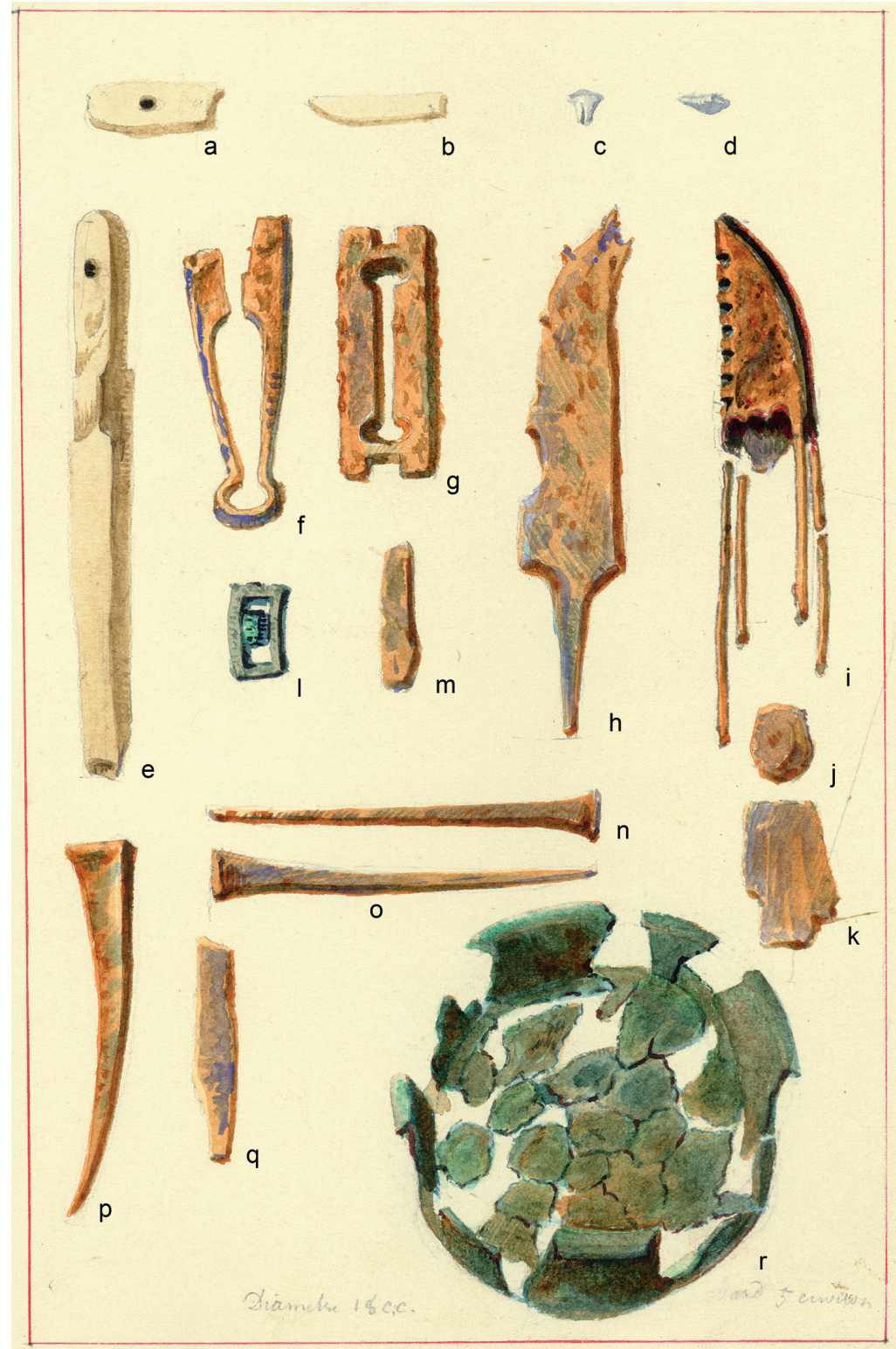

Ryc. 4. Zabytki z rozkopywań L. de Fleury’ego w Rusi, pow. łomżyński, z grobu nr 6 a, b, e - osełki; c, d, j, k - fragmenty nieokreślonych przedmiotów; f - nożyce; g - krzesiwo; h, m, q - noże; i okucie pochwy noża; 1 - sprzączka; n-p - gwoździe; $r$ - misa.

Wg RONA IIMK, zb. 1, 1-1890/28, k. 12; opracował M. Dzik

Fig. 4. Finds from de Fleury's excavations in Ruś, Łomża district, grave 6 a, b, e - whetstone; c, d, j, k - fragments of unidentified objects; $\mathrm{f}$ - shears; $\mathrm{g}$ - striker; $\mathrm{h}, \mathrm{m}, \mathrm{q}$ - knives; $\mathrm{i}$ - knife sheath fitting; 1 - buckle; $n-p$ - nails; $r$ - bowl. 
Małych i Rusi, w ówczesnej gub. łomżyńskiej. Do sprawozdania L. de Fleury dołączył również opis grobu rozkopanego przez Władysława Mościckiego w Grodzisku, w gub. siedleckiej (obecnie cmentarzysko na gruntach Niewiadomej, gm. Sabnie, pow. sokołowski, woj. mazowieckie).

W końcowym podsumowaniu tekstu zawarł krótkie uwagi dotyczące cech antropologicznych badanych szkieletów. Dla uzupełnienia przytoczył również wymiary kości szkieletów odkrytych w Żarnówce (obecnie gm. Grębków, pow. węgrowski, woj. mazowieckie), w trakcie wykopalisk przeprowadzonych przez Tymoteusza Łuniewskiego (o wynikach tych prac: Łuniewski 1882). Opis i rysunki podał niewątpliwie za artykułem Izydora Kopernickiego (1883, s. 17-31). Wywody L. de Fleury'ego na temat rozprzestrzenienia, interpretacji antropologicznej oraz etnicznej cmentarzysk i pochówków mają wartość jedynie historiograficzną. Znaczenie ma druga $\mathrm{z}$ wymienionych części tekstu, spisana na 12 stronach rękopisu (RONA IIMK, zb. 1, 1-1890/28, k. 5-11), która jest właściwym sprawozdaniem z wykopalisk i zostanie przedstawiona niżej.

Pomocniczą rolę w rekonstrukcji wyników badań L. de Fleury’ego na cmentarzyskach pełnią materiały $\mathrm{z}$ archiwum prywatnego A. Spicyna (RONA IIMK, zb. 5, sygn. 1/21, k. 6r). Wśród jego odręcznych notatek znajdują się rysunki kilku znalezisk z rozkopywań w 1892 r., szkic kurhanu oraz wizualizacja przekroju grobu odkrytego przez de Fleury'ego (RONA IIMK, zb. 5, sygn. 372, k. 279-281) ${ }^{15}$. Niewątpliwie wszystkie są kopiami ilustracji przesłanych przez hrabiego do CKA. Możliwe, że przekrój grobu odnosi się do obiektu nr 6 z Rusi, którego rysunek znajdował się w sprawozdaniu (por. wyżej; ryc. 1b). Nie jest to jednak jedyna ewentualność. Otóż, przy szkicu A. Spicyn zapisał wymiary, które można odnieść do warstw nad brukiem $\mathrm{w}$ obrębie obstawy $(6 \mathrm{cali}=$ około $15 \mathrm{~cm})$ oraz pod nim $(9-12 \mathrm{cali}=$ 23-30 cm). Podał także informację o kłodzie dębowej i gwoździach, skręconych w górnej części. Dane te odpowiadają opisowi tylko jednego grobu, nr 1, z Rostek Małych (Kotówka). Nic jednak nie wiadomo, aby rysunek tego obiektu miał znajdować się w sprawozdaniu. Warto też pamiętać, że A. Spicyn mógł wykonać przerysy $\mathrm{z}$ ilustracji nadsyłanych $\mathrm{w}$ kolejnych latach przez L. de Fleury'ego. Obecnie najbardziej prawdopodobne wydaje się, że ów szkic to ogólny schemat stratygrafii grobów w obudowach kamiennych.

Wśród rysunków zabytków wykonanych przez A. Spicyna można rozpoznać: esowaty kabłączek skroniowy, wity pierścień (ze znakiem zapytania, możliwe, że badacz nie był pewny, co do formy lub techniki wykonania ozdoby), gwóźdź, okucie naczynia i krzesiwo ogniwkowe. Dwa ostatnie można identyfikować z zabytkami, odpowiednio, z grobu nr 1 w Rostkach Małych (Kotówku) i pochówku nr 6c w Rusi (ryc. 2h, i; 4g). Spicyn zauważył również, że w materiałach wykopaliskowych jest „mało” paciorków i wspomniał o obecności „bladych ametystowych”. Na koniec podał listę cmentarzysk

${ }^{15}$ Przy rysunku przekroju grobu A. Spicyn napisał w cyrylicy „Grodn.”, co może być rozumiane jako wskazanie na gubernię grodzieńską. Jest to oczywista pomyłka, jako że L. de Fleury nie organizował wykopalisk w tej guberni. Należy jednak pamiętać, że prace swe prowadził blisko jej granicy, a majątek Kępa, w którym hrabia mieszkał, znajdował się już na jej terenie. Obok rysunków zabytków, wykonanych przez A. Spicyna, znajduje się prawidłowa lokalizacja - „Lomž.[inskaâ] gub.[erniâ]”. 
wraz z odwołaniem do artykułu de Fleury’ego (1893, s. 334), którą zawarł w artykule z 1925 r. Dokładna data powstania notatek A. Spicyna nie jest znana.

Pozostałe rysunki i fotografie wykonane przez hrabiego lub związane $\mathrm{z}$ jego kolekcją, a znajdujące się w archiwach IIMK RAN, odnoszą się do innych stanowisk i dotarły do Petersburga innymi drogami. Rysunki grodziska w Samborach (Rusi) i rekonstrukcji szesnastowiecznego zamku w Wiźnie dostarczył do CKA N. Awenarius (RONA IIMK, zb. 1, 1-1889/42, k. 29, 30). W zachowanym albumie fotografii (Fotootdel Naučnogo arhiva IIMK RAN [dalej: FONA IIMK], sygn. O 754) znajduje się obecnie 10 zdjęć, w tym: sześć przedstawiających narzędzia krzemienne i ułamki naczyń neolitycznych, m.in. ze stanowiska w Kępie (FONA IIMK, sygn. O 754/5-11); jedno przedstawiające ułamki wczesnośredniowiecznych naczyń i innych wyrobów, zebrane na grodziskach w Samborach (Rusi) i Pieńkach-Okopnych (FONA IIMK, sygn. O 754/4; podpisane jako tablica V); trzy z fragmentami naczyń, kafli i innych przedmiotów z różnych okresów, zebranych na grodzisku w Wiźnie (FONA IIMK, sygn. O 754/1-3; podpisane jako tablice I-III).

$\mathrm{Z}$ istniejących $\mathrm{w}$ archiwum CKA informacji o pochodzeniu tych fotografii wynika, że trafily tam przez Cesarskie Rosyjskie Towarzystwo Archeologiczne w Petersburgu, a nie bezpośrednio od L. de Fleury’ego. Nie ma zatem pewności, czy są to te same fotografie, które były przedmiotem korespondencji z lat 1894-1895.

\section{CMENTARZYSKA W KOKOSZKACH, KOTÓWKU (ROSTKACH MAŁYCH) I RUSI W BADANIACH L. DE FLEURY’EGO}

Szczegółowy opis cmentarzysk, grobów i ich zawartości zamieszczono w innym miejscu (Musin, Dzik [w druku]). W dalszej części artykułu podano informacje najistotniejsze z punktu widzenia opracowania materiałów źródłowych i analizy ich znaczenia.

\section{POŁOŻENIE CMENTARZYSK}

Dokładną lokalizację stanowiska w Ko k o s z k a ch (Kokoszki, gm. Wizna, pow. łomżyński, stan. 1, AZP 35-78/21) ustalił L. Rauhut, w trakcie prospekcji terenowej w 1963 r. Położone jest na wyniesieniu, na lewym brzegu strugi Jedwabianki, dopływu Narwi (ryc. 5). Dwa lata wcześniej kamienie z konstrukcji grobów zostały zebrane, a cmentarzysko zaorane (Rauhut 1971, s. 617). W 2019 r. stanowisko było polem uprawnym (prospekcja M. Dzika). Według L. Rauhuta (1971, s. 617), zostało ono zniszczone w $100 \%$. Jeśli jednak znajdowały się tutaj groby jamowe, to część z nich może być zachowana, mimo zniszczenia konstrukcji kamiennych. Niewykluczone, że z tej nekropoli pochodzi bransoleta brązowa o analogiach bałtyjskich, odkryta w Kokoszkach, w bliżej nieokreślonym miejscu (Ościłowski 2013, s. 103, ryc. $5 ; 6)$. Dotychczas na stanowisku nie przeprowadzono profesjonalnych badań wykopaliskowych. 


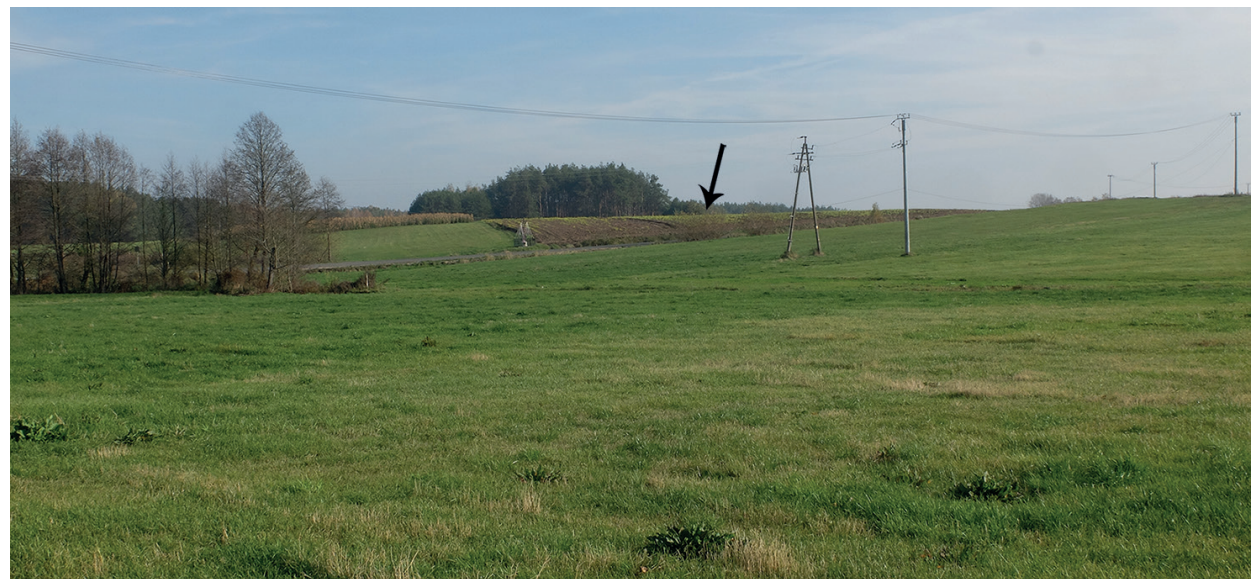

Ryc. 5. Kokoszki, pow. łomżyński, stan. 1. Widok z północnego zachodu; październik 2019 r.

Fot. M. Dzik

Fig. 5. Kokoszki, Łomża district, site 1. View from the northwest; October 2019.

Photo M. Dzik

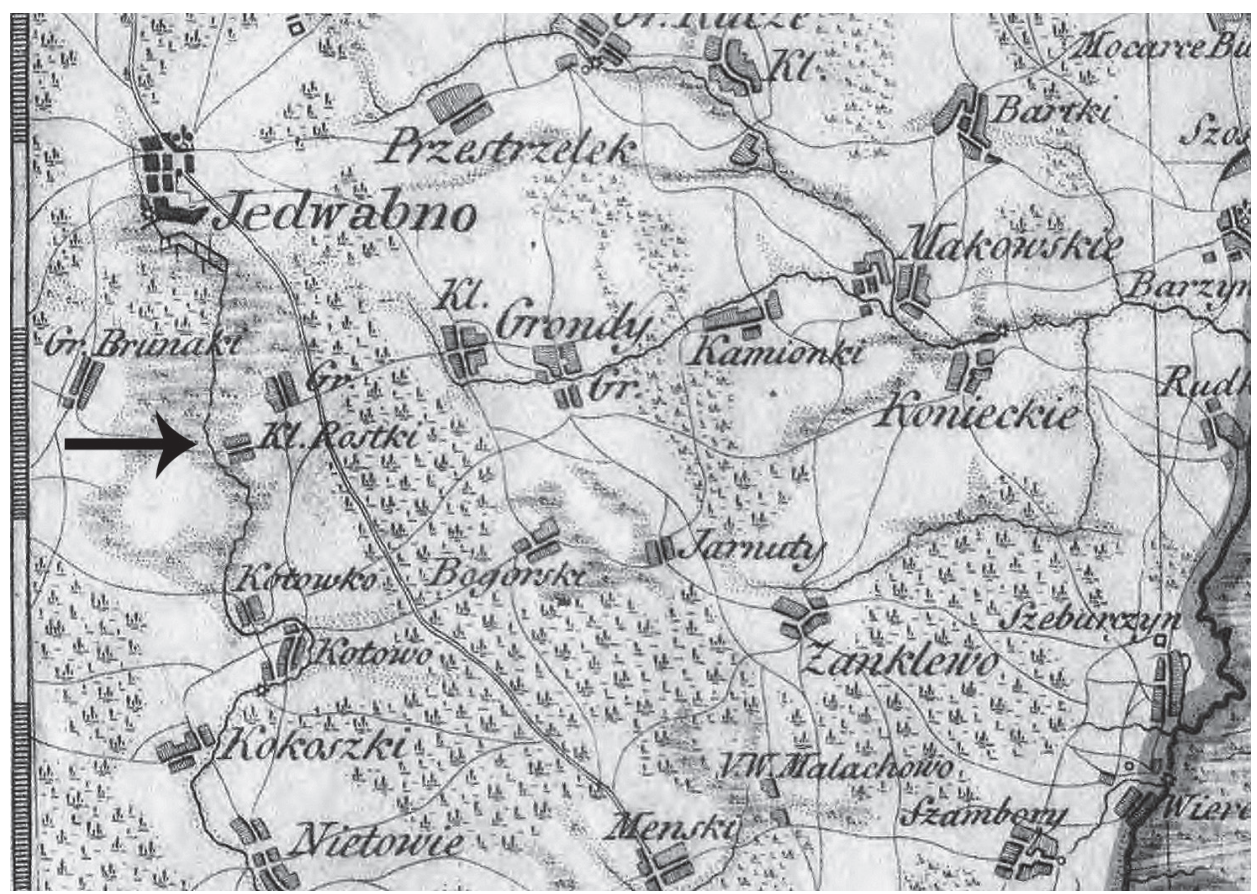

Ryc. 6. Rostki Małe na mapie topograficznej z początku XIX w.

Wg TMK 1808; opracował M. Dzik

Fig. 6. Rostki Małe on a topographic map from the beginning of the $19^{\text {th }} \mathrm{c}$.

After TMK 1808; processing M. Dzik 


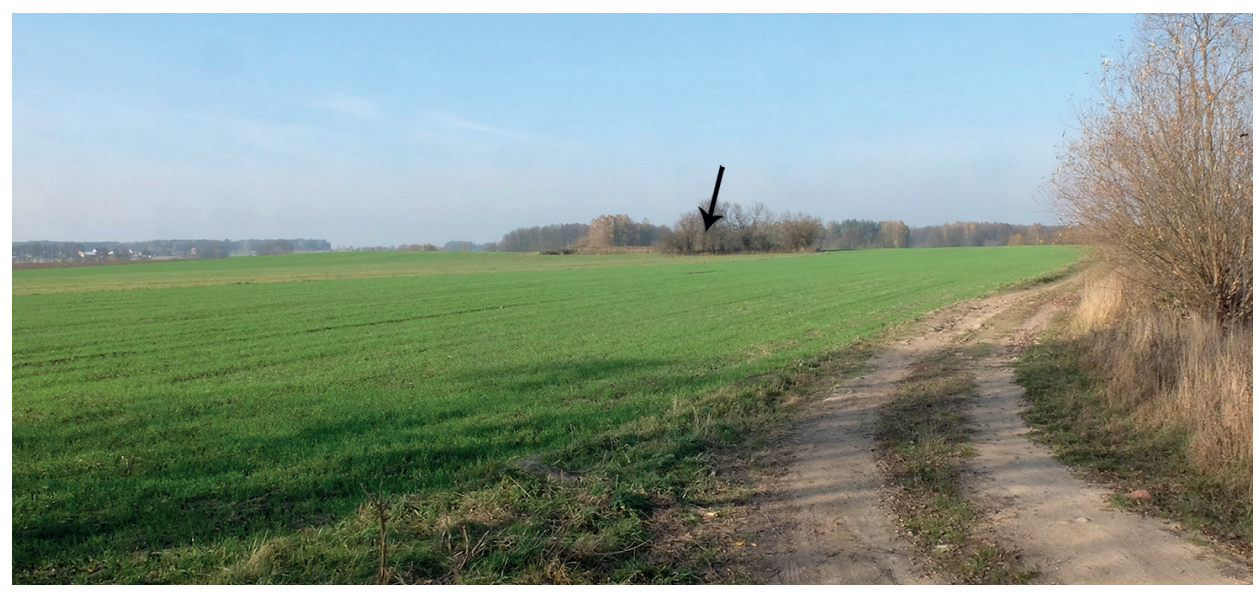

Ryc. 7. Kotówek, pow. łomżyński, stan. 1. Widok z południowego wschodu; październik 2019 r.

Fot. M. Dzik

Fig. 7. Kotówek, Łomża district, site 1. View from the southeast; October 2019.

Photo M. Dzik

Nieco więcej trudności przyniosło badaczom ustalenie położenia cmentarzyska w Rostkach Małych (Kotówek, gm. Jedwabne, pow. łomżyński, stan. 1, AZP 35-78/15). Osada Rostki Małe, obecnie nieistniejąca, w 1827 r. liczyła jeden dom i siedmiu mieszkańców (Tabella 1827, s. 143). Zapewne zanikła do lat trzydziestych XIX w., skoro nie naniesiono jej na Mapę Kwatermistrzostwa (TKKP [1839] 1843). Położona była na południowy zachód od Rostek Dużych (obecnie Rostki), na wzniesieniu tuż nad strugą Wiźnicą (obecnie Jedwabianka), na lewym jej brzegu (ryc. 6; 7). W 1955 r. na tej samej wyniosłości, ale opisanej jako leżąca na gruntach wsi Kotowo-Plac, na polu zwanym „Rostki” i „Łysa Góra”, przy kopaniu żwiru odkryto trzy groby szkieletowe. Kości oraz materiał zabytkowy zostały zniszczone; znanych jest jedynie pięć paciorków szklanych, odkrytych w jednym z grobów i opublikowanych przez Jana Jaskanisa (1956a; 1956b). Tożsamości cmentarzysk w Rostkach Małych i Kotowie-Placu trafnie domyślał się L. Rauhut (1971, s. 618). W 1997 r. przeprowadzono na stanowisku kilkudniowe badania ratownicze, w związku z jego niszczeniem przy wybieraniu piasku (Trzciński, Skowron 2006). Odkryto jedynie dwa ułamki naczyń wczesnośredniowiecznych, kilka przepalonych kości oraz liczne wkopy nowożytne. Cmentarzysko opisano wówczas pod nazwą Kotówek, stan. 1. Obecnie znajduje się w granicach gruntów tej wsi. L. Rauhut (1971, s. 617) stwierdził, iż jest ono całkowicie zniszczone. Na podstawie własnych prospekcji terenowych (2019 r.) autor niniejszej pracy sądzi jednak, że groby mogły zachować się na południowo-wschodnim skraju cmentarzyska, nieobjętym eksploracją żwiru i piasku. Widoczne są tutaj głazy częściowo zagłębione, w tym tworzące dwa regularne rzędy i prawdopodobnie stanowiące pozostałość obstaw grobowych (ryc. 8). 


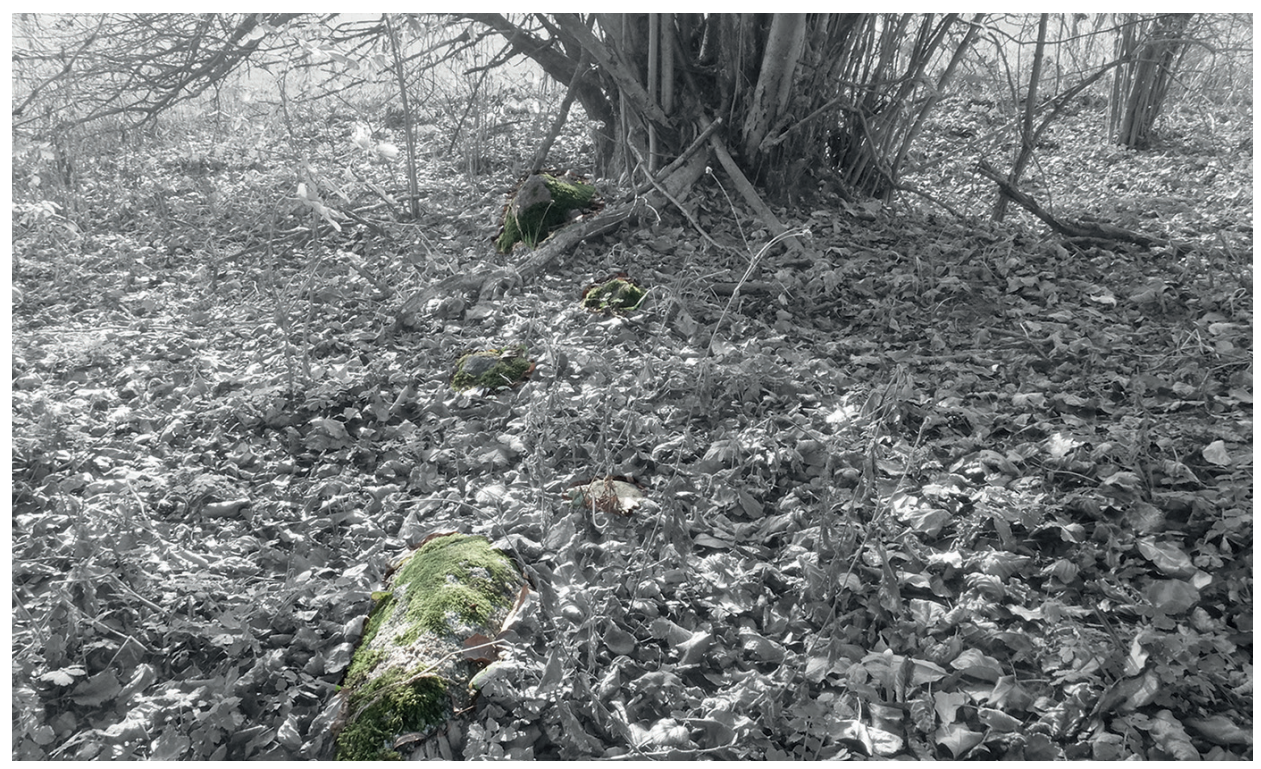

Ryc. 8. Kotówek, pow. łomżyński, stan. 1. Szczyty kamieni obstaw dookolnych, zachowane in situ (?); październik $2019 \mathrm{r}$.

Fot. M. Dzik

Fig. 8. Kotówek, Łomża district, site 1. Tops of the stones from the grave lining, preserved in situ (?); October 2019

Photo M. Dzik

Cmentarzysko w Rusi (Ruś, gm. Wizna, pow. łomżyński, stan. 7, AZP 36-79/25) przez długi czas uchodziło za badane jedynie powierzchniowo przez L. de Fleury i traktowano jego wczesnośredniowieczną metrykę jako niepewną (por. Rauhut 1971, s. 618-619). Znajdujące się na nim konstrukcje kamienne zostały zniszczone i stanowiska nie udało się zlokalizować, ani w trakcie archeologicznych prospekcji terenowych, ani w badaniach powierzchniowych AZP.

Kilka istotnych wiadomości o jego położeniu podał L. de Fleury (RONA IIMK, zb. 1, 1-1890/28, k. 7). Miało znajdować się na wyniesionej nad doliną Narwi „płaszczyźnie” i nosić wśród mieszkańców nazwę „Brukanki” (nazwa zapisana w rękopisie również w alfabecie łacińskim). W ciągu 15 lat poprzedzających rozkopywania de Fleury’ego (1892 r.) cmentarzysko miało służyć jako kamieniołom dla mieszkańców Wizny i wówczas zostało już w większości zniszczone. Kilka „polan” (zapewne miejsc z pozostałościami grobów w obudowach kamiennych) przetrwało w trzech lub czterech miejscach, daleko od siebie. Według mieszkańców, owe „polany” stanowiły niegdyś ciągły „łańcuch” grobów o długości kilkuset metrów. Kolejna informacja podana w sprawozdaniu dotyczy grobu nr 11, który znajdował się w części cmentarzyska położonej na polu Wolińskiego - brata sołtysa Rusi. Z kolei czaszkę z grobu nr 12 znaleziono „około czterdziestu kroków poniżej innych grobów, jeśli 
podejść do wioski z południa, w wykopanym przez chłopów dole do przechowywania ziemniaków, a następnie przez nich porzuconym" (RONA IIMK, zb. 1, 1-1890/28, k. 9). W opisie tego znaleziska de Fleury zanotował też, iż „najwyraźniej pochówki zaczęły się od szczytu (tj. kulminacji wzniesienia) i tylko pomału zaczęły być grzebane na stoku wzgórza ku południowi”. Kolejny grób, nr 9, miał znajdować się „na szczycie wzgórza” (RONA IIMK, zb. 1, 1-1890/28, k. 10r). Podsumowując, cmentarzysko miało ciągnąć się od drogi Wizna-Radziłów do skłonu kulminacji, od około czterystu do kilkudziesięciu metrów od zabudowań, a w 1892 r. zachowane były trzy lub cztery jego niewielkie fragmenty, bardzo oddalone od siebie; w niektórych z tych miejsc kopcowano ziemniaki.

W lipcu 2020 r. autor artykułu przeprowadził prospekcję terenową w Rusi. Obecnie na terenie rodziny Wolińskich znajduje się jedno miejsce określane jako „Brukanica” i „Kopce”, zwane tak ze względu na dawną obecność kamieni (zwożonych z pól, według pamięci informatora) oraz niegdysiejsze kopcowanie ziemniaków (ryc. 9a1) ${ }^{16}$. Jest to nieużytek o powierzchni około 3 arów, położony w górnej partii południowo-wschodniego skłonu terasy nadzalewowej Narwi (ryc. 10). W trakcie prospekcji teren porośnięty był wysoką trawą uniemożliwiającą zaobserwowanie, czy znajdują się tutaj szczyty większych kamieni leżących w gruncie. W zagajniku w bliskim sąsiedztwie „Brukanicy” widoczne są pojedyncze kamienie, w tym o długości ponad $0,5 \mathrm{~m}$ i niemal w całości zagłębione w gruncie. Nie stwierdzono jednak takich ich układów, które jednoznacznie można by interpretować jako pozostałość obstaw grobowych. Należy zaznaczyć, że eratyki widoczne są także na innych obszarach Rusi. Zważywszy jednak na nazwę, własność gruntów oraz ich położenie, wskazane wyżej miejsce wydaje się obecnie najbardziej prawdopodobną lokalizacją części nekropoli opisanej przez L. de Fleury’ego.

Kolejna wiadomość, potencjalnie przydatna dla ustalenia lokalizacji cmentarzyska, dotyczy grobu nr 2. Miał on się znajdować na zachodnim końcu drogi prowadzącej od Rusi do niewielkiej drogi z Wizny do Radziłowa, w miejscu, które według L. de Fleury’ego prawdopodobnie stanowiło zachodni kraniec cmentarzyska (RONA IIMK, zb. 1, 1-1890/28, k. 7r). Wydaje się, że należy wziąć pod uwagę trzy drogi, zapewne istniejące $\mathrm{w}$ tamtym czasie, a znajdujące się stosunkowo blisko tzw. Brukanki na polu Wolińskich, widoczne na mapie z 1915 r. (ryc. 9b). Obecnie najbardziej prawdopodobna wydaje się lokalizacja najbliższa wspomnianemu nieużytkowi (ryc. 9b2). Teren ten jest poddany regularnej uprawie i na powierzchni brak śladów konstrukcji kamiennych.

Pierwotne rozmiary trzech cmentarzysk są niemożliwe do ustalenia z powodu znacznego ich zniszczenia jeszcze przed obserwacjami poczynionymi przez L. de Fleury’ego. Stanowisko w Kokoszkach miało liczyć w 1892 r. 30 grobów w obudowach kamiennych widocznych na powierzchni gruntu, ale niegdyś miało być znacznie większe. Co najmniej kilkadziesiąt grobów z takimi konstrukcjami musiało znajdować się w Kotówku (Rostkach Małych), skoro przed 1892 r. miano stamtąd

${ }^{16}$ Autor artykułu składa podziękowania Czesławowi Wolińskiemu (ur. 1931) i jego córce, Celinie Wader, za udzielone informacje. 

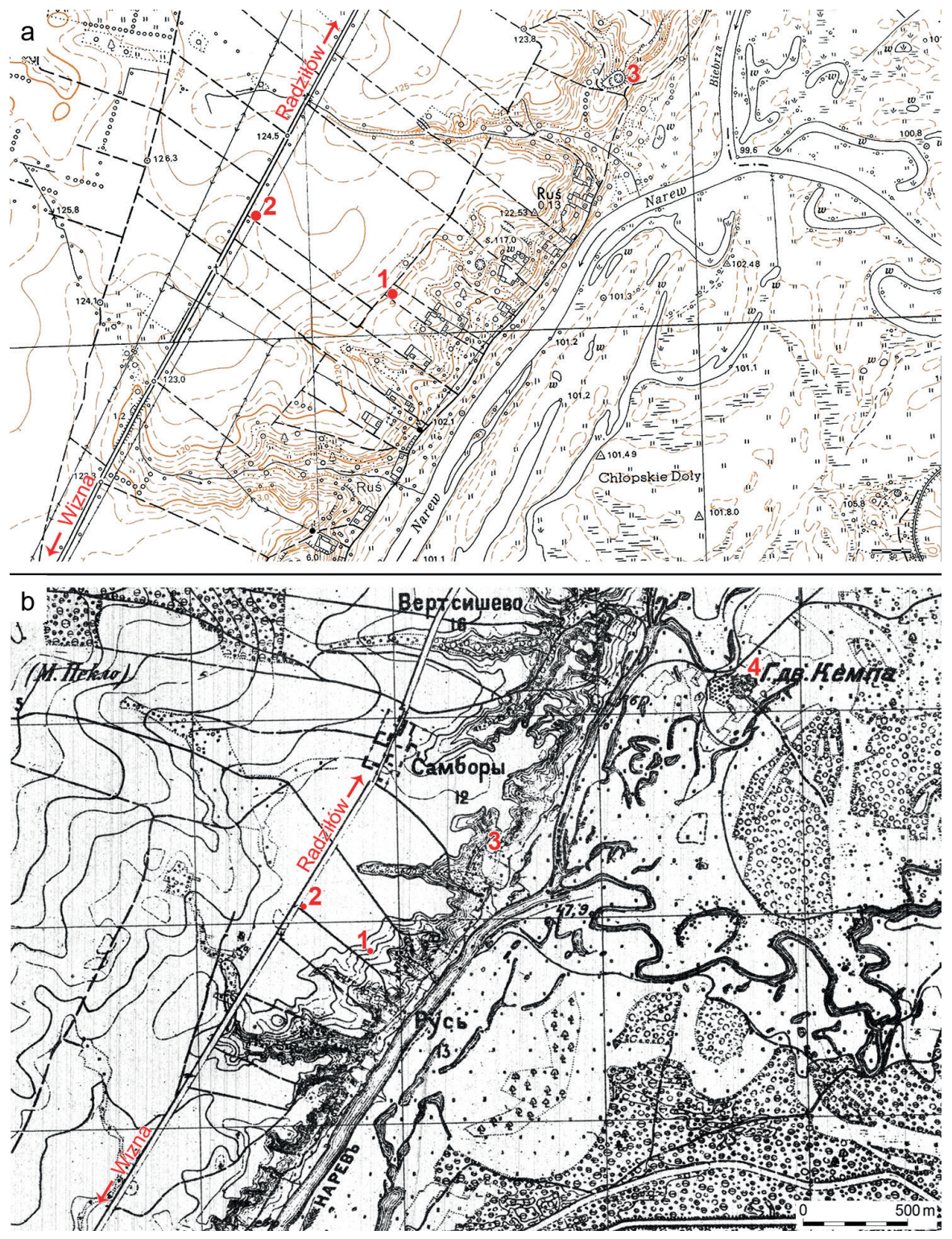

Ryc. 9. Ruś, pow. łomżyński, na mapach topograficznych z 1980 (a) i 1915 r. (b)

1 - nieużytek „Brukanica”; 2 - przypuszczalna lokalizacja grobu nr 2; 3 - grodzisko w Samborach; 4 - dwór w Kępie Giełczyńskiej, majątek L. de Fleury’ego.

Wg Mapa 1980 i Osteuropa 1915; opracował M. Dzik

Fig. 9. Ruś, Łomża district, on topographic maps from 1980 (a) and 1915 (b)

1 - "Brukanica" wasteland; 2 - alleged localization of grave 2; 3 - the Sambory stronghold site; 4 - manor house in Kępa Giełczyńska, L. de Fleury's estate. 


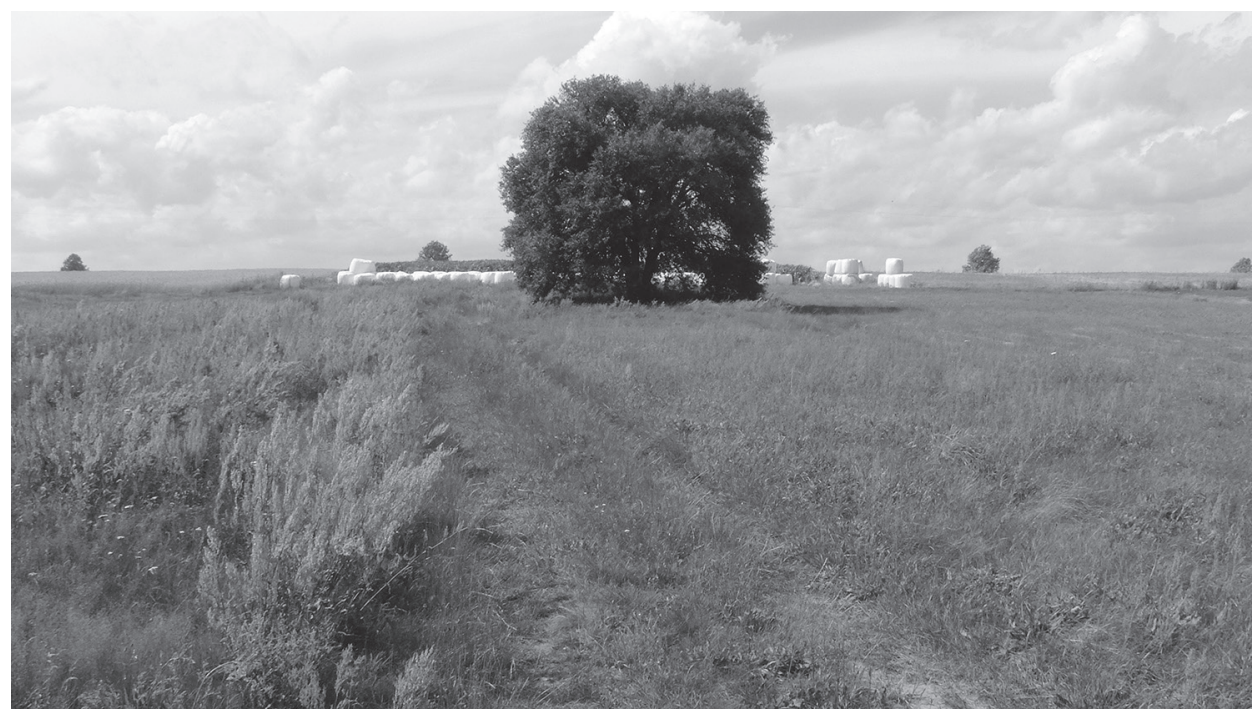

Ryc. 10. Ruś, pow. łomżyński, nieużytek „Brukanica”; widok z południowego wschodu; lipiec 2020 r.

Fot. M. Dzik

Fig. 10. Ruś, Łomża district, "Brukanica” wasteland; view from the southeast; July 2020.

Photo M. Dzik

wywieźć 30 wozów kamieni, a w trakcie wykopalisk rozkopano co najmniej pięć grobów z zachowanymi obudowami. Szczególnie duże miało być cmentarzysko w Rusi. Według wiadomości zebranych przez L. de Fleury’ego, zachowane wówczas jego części były niegdyś połączone rzędami grobów, musiały zatem tworzyć nekropolę o długości kilkuset metrów. Możliwe jednak, że groby zakładano na nim zgodnie z modelem policentrycznym (por. Dzik 2015, II, s. 114-115). W tej sytuacji mogło tu powstać kilka oddzielnych skupisk grobów. Wydaje się to bardziej prawdopodobne, bowiem nekropole mierzące „kilkaset metrów” zwarcie zabudowanych grobami nie są znane także z sąsiednich regionów. Potwierdzone są natomiast przypadki, gdy takie skupiska oddalone były od siebie o kilkaset metrów ${ }^{17}$. Należy dodać, że na każdym z opisanych cmentarzysk mogły występować również groby wziemne (bez konstrukcji kamiennych), co poniekąd sugerują informacje na temat grobu nr 12 z Rusi.

Podsumowując, wszystkie wymienione nekropole zajmowały kulminacje i stoki wysoczyzn. Oddalone były od cieków wodnych o około $150 \mathrm{~m}$ (Kokoszki), $350 \mathrm{~m}$ (Ruś) i $450 \mathrm{~m}$ (Kotówek [Rostki Małe]). Zwraca uwagę fakt, iż dwa z nich położone są nad strugą Wiźnicą (Jedwabianką), uchodzącą do Narwi w pobliżu Wizny.

Najbliżej względem znanych grodzisk z tego okresu znajduje się cmentarzysko w Rusi - około 0,8 km od obiektu w Samborach (Rusi) i około 3,7 km od

${ }^{17}$ Np. w pow. siemiatyckim cmentarzyska w Smarklicach stan. 2 i 5 dzieli 150 m, a nekropole w Smolugach, stan. 1 i Dołubowie, stan. 1 - około 300 m (Dzik 2015, I, s. 138, II, s. 118, ryc. 23). 
Wizny. Drugie z wymienionych jest najbliższym grodziskiem względem Kokoszek i Kotówka, które są oddalone od Wizny odpowiednio o około 7,5km i 9,1km.

\section{KONSTRUKCJE GROBOWE}

Wiadomości podane przez L. de Fleury’ego pozwalają przyjąć, że co najmniej 18 z 19 grobów wyróżnionych na rozkopanych przez niego cmentarzyskach miało konstrukcje kamienne (w liczbie tej nie uwzględniono kilku mogił rozkopanych w Kotówku, mających czworokątne obstawy kamienne, ale nieopisanych i niewyróżnionych osobnymi numerami). Wyjątek mógł stanowić grób $\mathrm{nr} 12$ z Rusi, który został zniszczony przez okolicznych mieszkańców i w którym podobno nie było kamieni. Niezależnie od tej informacji, wobec braku profesjonalnych badań wykopaliskowych, obecność grobów wziemnych (tj. jamowych bez konstrukcji kamiennej przykrywającej jamę) jest możliwa na każdym z tych cmentarzysk. Warto bowiem pamiętać, że L. de Fleury rozkopywał i opisywał jedynie te groby, które miały widoczne na powierzchni obstawy, a to determinuje obecne wyobrażenie o konstrukcji wszystkich grobów na tych nekropolach.

Z opisów 18 grobów wynika, że otoczone były obstawami z głazów, których szczyty widoczne były na powierzchni. Kształty obstaw zostały określone jako: koliste, owalne i czworokątne. Według L. Rauhuta, „chodzi tu raczej o naruszone i nieregularne obstawy prostokątne lub o zarys zewnętrzny obudów", jako że znane mu $z$ innych cmentarzysk groby miały zawsze kształt prostokątny od strony wewnętrznej obstawy (Rauhut 1971, s. 617, 618). Zestawienie wiadomości podanych przez L. de Fleury'ego o konkretnych grobach pokazuje, iż jako kolisty określił tylko jeden, wyjątkowo dużych rozmiarów obiekt (tabela 1). L. de Fleury nie prowadził dokładnych pomiarów konstrukcji grobowych, nie rysował ich planów, a sugerował się jedynie obserwacjami w terenie. Wątpliwości L. Rauhuta odnośnie do kształtów grobów są tym samym słuszne. Niemniej jednak nie można wykluczyć, że niektóre miały kształt owalny bądź zbliżony do kolistego. Takie groby w obudowach udokumentowano bowiem na przykład na cmentarzysku w Podrosi, rej. wołkowyski (D. Jaskanis 1962).

W sprawozdaniu podano wymiary sześciu grobów (tabela 1). W czterech przypadkach jest pewne lub bardzo prawdopodobne, iż były to rozmiary wewnętrzne obstaw dookolnych, widocznych na powierzchni terenu. $Z$ tego względu jest możliwe, że L. de Fleury właśnie takie wymiary podał także w dwóch pozostałych przypadkach (groby nr 2, 2a w Kokoszkach i nr 1 w Kotówku [Rostkach Małych]). Spośród grobów z pochówkami szkieletowymi największy miał szerokość i długość około $4 \mathrm{~m}$, najmniejszy $1,2 \times 2,0 \mathrm{~m}$. Wymiary te mieszczą się w granicach odnotowywanych w regionach sąsiednich (Kordala 2006, s. 114-115; Dzik 2015, II, s. 41, ryc. 8-11). Wyjątkowo małych rozmiarów był ciałopalny grób nr 9 z Rusi. Fakt ten niekoniecznie musiał być związany z odmiennym rytem pogrzebowym, który teoretycznie nie wymagał tak dużej przestrzeni na pochówek, jak w przypadku inhumacji. W sąsiednim międzyrzeczu wschodniego odcinka dolnego Bugu i Narwi groby 
Tabela 1. Cechy obstaw oraz klasyfikacja konstrukcji grobów zbadanych przez L. de Fleury’ego

Table 1. Features of the stone structures and classification of grave structures investigated by L. de Fleury

\begin{tabular}{|c|c|c|c|c|}
\hline Nr grobu & $\begin{array}{c}\text { Kształt } \\
\text { obstawy }\end{array}$ & $\begin{array}{c}\text { Wymiary } \\
\text { obstawy (m) }\end{array}$ & \begin{tabular}{|l|} 
Typ grobu wg \\
Dzika (2015) \\
\end{tabular} & Uwagi \\
\hline \multicolumn{5}{|c|}{ Kokoszki, stan. 1} \\
\hline 1 & & & I & $\begin{array}{c}\text { głazy obstawy płaskie, pionowo } \\
\text { ustawione }\end{array}$ \\
\hline $2,2 \mathrm{a}$ & $\begin{array}{c}\text { nieregularnie } \\
\text { owalny }\end{array}$ & $1,7 \times 4,2$ & I & $\begin{array}{c}\text { szer. i łączna dł. wewn. lub zewn. } \\
2 \text { grobów stykających się ścianami } \\
\text { szczytowymi; głazy płaskie, pionowo } \\
\text { ustawione }\end{array}$ \\
\hline 3 & & & I & $\begin{array}{c}\text { głazy obstawy płaskie, pionowo } \\
\text { ustawione }\end{array}$ \\
\hline \multicolumn{5}{|c|}{ Kotówek (Rostki Małe), stan. 1} \\
\hline 1 & kolisty & 4 & II.1 & wymiary wewn. lub zewn.; 11 głazów \\
\hline 2 & owalny & $3,0 \times 3,14$ & I, ew. II.1 & wymiary wewn.; 14 głazów \\
\hline 3 & czworokątny & & I, ew. II.1 & \\
\hline kilka grobów & czworokątne & & I, ew. II.1 & \\
\hline \multicolumn{5}{|c|}{ Ruś, stan. 7} \\
\hline 1 & & & I, ew. II.1 & \\
\hline 2 & & $1,2 \times 2,0$ & II.1? & $\begin{array}{c}\text { wymiary zapewne wewn.; } \\
\text { bardzo duży głaz od strony nóg }\end{array}$ \\
\hline 3 & & & I, ew. II.1 & \\
\hline 4 & & & I, ew. II.1 & \\
\hline 5 & owalny & & I, ew. II.1 & \\
\hline 6 & \begin{tabular}{|c|}
$\begin{array}{c}\text { nieregularnie } \\
\text { owalny }\end{array}$ \\
\end{tabular} & $2 \times 2,8$ & I, ew. II.1 & $\begin{array}{c}\text { wymiary zapewne wewn.; } \\
\text { grób zbiorowy }\end{array}$ \\
\hline 7 & czworokątny & & I, ew. II.1 & grób zbiorowy \\
\hline 8 & & & I, ew. II.1 & \\
\hline 9 & & $0,5 \times 1,2$ & II.1 & wymiary wewn.; grób ciałopalny \\
\hline 10 & & & I, ew. II.1 & $\begin{array}{c}\text { bardzo duży głaz od strony } \\
\text { nóg (NNE) }\end{array}$ \\
\hline 11 & & & I, ew. II.1 & \\
\hline 12 & brak? & & III? & \\
\hline
\end{tabular}

Objaśnienia: dł. - długość, szer. - szerokość, wewn. - wewnętrzna, zewn. - zewnętrzna. Key: dł. - length, szer. - width, wewn. - inner, zewn. - outer.

$\mathrm{w}$ obudowach kamiennych z pochówkami ciałopalnymi miały rozmiary typowe dla szkieletowych i w żadnym przypadku nie zbliżyły się do wymiarów omawianego obiektu $^{18}$. Na tamtym obszarze odnotowano równie niewielkie konstrukcje jak

${ }^{18} \mathrm{~Np}$. Twarogi Lackie, stan. 9, grób nr $12(1,7 \times 0,8 \mathrm{~m})$; Krasewice-Czerepy, stan. 1, grób nr $6(2,1 \times 1,0 \mathrm{~m})$; Skiwy Małe, stan. 1, grób $\mathrm{nr} 10(2,2 \times 1,2 \mathrm{~m})$, wszystkie w pow. siemiatyckim. Podano wymiary wewnętrzne obstaw dookolnych. 
grobu nr 9, ale najprawdopodobniej z pochówkami szkieletowymi, dziecięcymi ${ }^{19}$. Możliwe więc, że niewielkie rozmiary grobu z Rusi były pochodną wieku zmarłego, a nie zastosowania ciałopalenia.

W każdym z grobów przestrzeń wewnątrz obstawy wypełniona była brukiem. Jego miąższość podano tylko dla grobów w Kokoszkach, gdzie wynosiła 0,15$0,20 \mathrm{~m}$. W dwóch obiektach uwagę L. de Fleury’ego zwróciły duże kamienie bruku, tj. w grobie nr 1 w Kotówku (Rostkach Małych) i nr 7 w Rusi. W tym ostatnim bardzo duży kamień miał przykrywać część środkową szkieletu nr 7b. Zwyczaj umieszczania większych eratyków na zmarłym ma potwierdzenie w znaleziskach, choć nielicznych, z Mazowsza Północnego i Wysoczyzny Drohiczyńskiej (Dzik 2006, s. 60; tenże 2015, II, s. 150-151, tabela 17 - tam dalsza literatura).

Szkielety odkrywano bezpośrednio pod brukami, zapewne najczęściej na wysokości spągu obstawy, jak sugerują opisy przebiegu rozkopywania grobów oraz miąższość bruków. W trzech przypadkach autor sprawozdania zawarł uwagi, które wskazują na obecność pod brukami płytkiej jamy lub taką sugerują. I tak, przy opisie grobu nr $1 \mathrm{w}$ Rostkach Małych wspomniał o jamie głębokości 0,25 m. $\mathrm{Z}$ kolei $\mathrm{w}$ grobie $\mathrm{nr} 2 \mathrm{w}$ Rusi dobry stan zachowania szkieletu, a także uwaga o odkryciu go w piaszczystej warstwie sugerują, iż zalegał w płytkiej jamie. Czworokątna jama, której długość boku wynosiła $0,75 \mathrm{~m}$, miała znajdować się w grobie nr 9 w Rusi.

Podsumowując, spośród 19 wyróżnionych mogił 18 można zaliczyć do grobów w obudowach kamiennych, w tym większość najprawdopodobniej do typu I (tj. bezjamowych), a co najmniej trzy do grobów typu II.1 (z płytkimi jamami; typologia w: Dzik 2015, II, s. 39-46). Przewagę grobów typu I sugeruje również stan zachowania szkieletów - w zdecydowanej większości szczątkowy, co jest typowe dla grobów bezjamowych. W jednym przypadku - grobu nr 12 w Rusi istnieją podstawy do zaliczenia go do typu III (jamowy bez bruku lub bez obstawy dookolnej).

\section{POCHÓWKI}

W 17 z 19 wyróżnionych grobów odkryto fragmenty kości z 20 pochówków opisanych jako szkieletowe. W kolejnym grobie - nr 4 w Rusi - kości nie znaleziono, jednak zważywszy na szczątkowy stan zachowania szkieletów w większości grobów, istnieje bardzo duże prawdopodobieństwo, iż w tym także znajdował się pochówek inhumacyjny, ale uległ on pełnemu rozkładowi (por. Dzik 2015, II, s. 55).

L. de Fleury szczególną uwagę zwracał na obserwacje antropologiczne, stąd jego opisy stanu zachowania szkieletów są stosunkowo najpełniejsze. Wśród pochówków

19 Np. Czarna Wielka, pow. siemiatycki, stan. 1, groby nr $142(1,1 \times 0,6-0,9 \mathrm{~m}), \mathrm{nr} 224(1,1 \times 0,9 \mathrm{~m})$, $\mathrm{nr} 248(0,8 \times 0,5 \mathrm{~m})$. Podano wymiary wewnętrzne obstaw dookolnych (Bieńkowska, Dzik, Piasecka 2013 , s. 76, 100, 106). W wymienionych grobach kości uległy rozkładowi. Zjawisko to jest typowe dla płytko złożonych pochówków szkieletowych, natomiast nie występuje w przypadku podobnie zdeponowanych pochówków ciałopalnych (Dzik 2014b, s. 27). 
Tabela 2. Pochówki w grobach zbadanych przez L. de Fleury’ego

Table 2. Burials in the graves investigated by L. de Fleury

\begin{tabular}{|c|c|c|c|c|c|}
\hline Stanowisko & Nr grobu & Nr pochówku & $\begin{array}{l}\text { Orientacja } \\
\text { szkieletu } \\
\text { wg L. de } \\
\text { Fleury'ego } \\
\end{array}$ & $\begin{array}{l}\text { Płeć zmarłych } \\
\text { na podstawie } \\
\text { wyposażenia }\end{array}$ & Uwagi \\
\hline \multirow{4}{*}{$\begin{array}{c}\text { Kokoszki, } \\
\text { stan. } 1\end{array}$} & 1 & 1 & $\mathrm{~N}$ & & \\
\hline & 2 & 2 & $\mathrm{~S}$ & & \\
\hline & $2 \mathrm{a}$ & $2 \mathrm{a}$ & & & \\
\hline & 3 & 3 & & & \\
\hline \multirow{4}{*}{$\begin{array}{c}\text { Kotówek } \\
\text { (Rostki Małe), } \\
\text { stan. } 1\end{array}$} & 1 & 1 & $\mathrm{E}$ & M & $\begin{array}{c}\text { czaszka na } \\
\text { prawym boku }\end{array}$ \\
\hline & 2 & 2 & & & \\
\hline & 3 & 3 & $S$ & $\mathrm{M}$ & \\
\hline & kilka grobów & & & & \\
\hline \multirow{15}{*}{ Ruś, stan. 7} & 1 & 1 & & & \\
\hline & 2 & 2 & SSW & K & $\begin{array}{c}\text { czaszka na } \\
\text { prawym boku }\end{array}$ \\
\hline & 3 & 3 & & $\mathrm{~K}$ & \\
\hline & 4 & & & $\mathrm{M}$ & \\
\hline & 5 & 5 & & & \\
\hline & \multirow{3}{*}{6} & $6 a$ & SW & & \\
\hline & & $6 \mathrm{~b}$ & SW & & \\
\hline & & $6 c$ & SW & M & $\begin{array}{l}\text { pochówek } \\
\text { birytualny? }\end{array}$ \\
\hline & \multirow[b]{2}{*}{7} & $7 \mathrm{a}$ & $\mathrm{NE}$ & & \\
\hline & & $7 b$ & $\mathrm{NE}$ & M & $\begin{array}{c}\text { czaszka na } \\
\text { lewym boku }\end{array}$ \\
\hline & 8 & 8 & & & \\
\hline & 9 & 9 & & & $\begin{array}{l}\text { pochówek } \\
\text { ciałopalny }\end{array}$ \\
\hline & 10 & 10 & SSW & & \\
\hline & 11 & 11 & & & \\
\hline & 12 & 12 & & & \\
\hline
\end{tabular}

Objaśnienia: K - kobieta; M - mężczyzna.

Key: $\mathrm{K}$ - female; $\mathrm{M}$ - male.

inhumacyjnych jedynie pięciokrotnie szkielety zachowały się dość dobrze, czyli przetrwały przynajmniej kości nóg, rąk i czaszka ${ }^{20}$. W pozostałych (75\%) odkryto jedynie pojedyncze fragmenty kości (por. de Fleury 1893, s. 332).

W grobach, w których możliwe było ustalenie układu szkieletów, stwierdzono, że leżały one na wznak. W opublikowanym artykule, w sumarycznym opisie układu zmarłych L. de Fleury podał, iż ułożeni byli z rękoma na miednicy (de Fleury

\footnotetext{
${ }^{20}$ Kokoszki, grób nr 1; Kotówek (Rostki Małe), grób nr 1; Ruś, groby nr 2, 6b, 7b.
} 
1893, s. 332). Pozwala to przyjąć, że przynajmniej w części pochówków taki był układ kości rąk (nie odnotowany w sprawozdaniu). W trzech przypadkach stan zachowania szkieletów pozwalał na ustalenie ułożenia czaszek - w każdym leżała ona na boku (tabela 2).

W przypadku 11 pochówków podano ich orientację. Zwraca uwagę fakt, iż $\mathrm{w}$ odniesieniu do cmentarzysk rozkopanych w pierwszej kolejności (Kokoszki, Kotówek [Rostki Małe]) zarejestrowano ją z odniesieniem do głównych kierunków świata (tabela 2). Z kolei w Rusi w każdym przypadku odnotowano mniejsze lub większe odchylenia od tych kierunków. Zasadny wydaje się domysł, iż jedynie w Rusi dokładniej mierzono orientację pochówków, być może przy użyciu kompasu. Te pomiary można uznać za wiarygodne, w przeciwieństwie do odnoszących się do pochówków z Kokoszek i Kotówka (Rostek Małych). Jeśli chodzi o te dwa stanowiska, słuszna jest opinia L. Rauhuta, iż są to kierunki jedynie przybliżone i pochówki w rzeczywistości nie były zorientowane na północ lub południe (Rauhut 1971, s. 617). Uwzględniając te wątpliwości, należy odnotować, iż niewątpliwie orientacja pochówków była zróżnicowana. Większość zmarłych złożono głową na zachód, z odchyleniem na południe. W przynajmniej trzech przypadkach pochowano ich głową na wschód, $\mathrm{z}$ odchyleniem na północ (tabela 2).

$\mathrm{Na}$ cmentarzyskach z grobami w obudowach kamiennych wschodnia orientacja zmarłych jest zdecydowanie częstsza w przypadku pochówków mężczyzn niż kobiet (Rauhut 1971, s. 462-463; Kordala 2006, s. 119-120; por. też Dzik 2015, II, s. 60, 62). Przesłanką wzmacniającą takie określenie płci jest wyposażenie dwóch spośród trzech pochówków o takiej orientacji: w grobie nr 1 z Kotówka odkryto m.in. grot włóczni, a w pochówku nr $7 \mathrm{~b}$ znaleziono m.in. osełkę. Przedmioty te są typowe dla pochówków mężczyzn (por. Kordala 2006, s. 143, tabela 39; Dzik 2015, I, s. 231,256$)$. Na podstawie wyposażenia w osełki jest bardziej prawdopodobne, że zmarłych płci męskiej pochowano również w grobach: nr 3 w Kotówku, nr 4 i 6c w Rusi. W ostatnim z wymienionych znaleziono misy brązowe, które również są charakterystyczne dla pochówków mężczyzn (Janowski 2003, s. 342). Z kolei wyposażenie pochówków nr 2 i 3 z Rusi, czyli liczne ozdoby głowy i szyi oraz przęślik, pozwalają je uznać za zapewne kobiece.

W jednym grobie, nr 9, w Rusi, odkryto kości przepalone. Z opisu w sprawozdaniu wynika, że nie znajdowały się w zwartym skupisku, ale w różnych częściach grobu, wraz z węglami drzewnymi. W kontekście grobów ciałopalnych warto jeszcze zwrócić uwagę na pochówek nr 6c. L. de Fleury odkrył tu wyraźne ślady działania ognia, w tym: przepalone kamienie, liczne węgle drzewne, ślady przepalenia misy brązowej. Uznał, iż nie był to pochówek ciałopalny ze względu na położenie szczątkowo zachowanych kości w układzie anatomicznym. Warto wziąć pod uwagę możliwość, iż był to pochówek birytualny. W takim przypadku zachowanie układu anatomicznego jest regułą, bowiem ogień rozpalano na lub przy zmarłym, złożonym wcześniej w rycie inhumacyjnym. Groby z takimi pochówkami znane są z dorzecza wschodniego odcinka dolnego Bugu (Dzik 2015, II, s. 79-82, 133-137 - tam dalsza literatura). 


\section{ZABYTKI RUCHOME}

Spośród 19 wyróżnionych grobów, w zaledwie jednym lub dwóch nie odkryto zabytków ruchomych (tabela 3). Wątpliwości odnośnie do liczby wynikają z braku możliwości jednoznacznego przypisania zabytków do grobów nr 2 i 2 a z Kokoszek. Obecnie możliwości ich analizy są z oczywistych względów bardzo ograniczone. Niemniej, posiadane informacje o znaleziskach umożliwiają porównanie ich ze znanymi z sąsiednich regionów. W poniższej analizie uwzględnione zostaną głównie materiały z Mazowsza i międzyrzecza Bugu i górnej Narwi. Z tych bowiem obszarów znane są groby w obudowach kamiennych i porównanie zabytków ruchomych z omawianych cmentarzysk ze znanymi z Mazowsza i obecnego Podlasia ma potencjalnie największe znaczenie dla ustalenia kierunku migracji przedmiotów, a może też ludzi.

Ozdoby i elementy stroju odkryto w co najmniej siedmiu grobach (32\%). W jednym lub dwóch przypadkach były to ozdoby głowy. Nie ma pewności co do funkcji zabytku z grobu nr 2 lub 2a, opisanego jako kółko połączone $\mathrm{z}$ dwoma witymi drutami. L. de Fleury zapisał, że nie jest w stanie stwierdzić, czy to jeden przedmiot, czy dwa. Nie był to zatem kabłąk zausznicy z nawiniętymi zwitkami, typowy m.in. dla zausznic paciorkowych (np. Dzik 2015, I, s. 220, ryc. 18: 14), ani też zausznica z wisiorkami, które też bywają spiralnie skręcone (np. Chilmon 1974, ryc. 5b, c). W tych bowiem przypadkach określenie liczby ozdób nie sprawiłoby trudności. Mogła to być natomiast odmiana zausznicy z drucianym oplotem (por. D. Jaskanis 2004; 2008, s. 201-203). W jej przypadku oplot mógłby bowiem obudzić wątpliwości osoby nieobeznanej z materiałem co do tego, czy razem z kabłąkiem tworzył pierwotnie jedną ozdobę.

$\mathrm{Z}$ ozdobami głowy mamy z pewnością do czynienia w grobie $\mathrm{nr} 2$ z Rusi. Odkryto w nim, przy czaszce szkieletu, 12 srebrnych lub posrebrzanych kabłączków skroniowych należących do typu III według Krystyny Musianowicz ([1948] 1949). Na podstawie rysunku nie można ustalić, czy ich esowate uszka były żłobkowane, czy gładkie, przy czym cecha ta ma znaczenie drugorzędne dla datowania tych zabytków. Istotniejsza z pewnością jest ich średnica (por. Kóčka-Krenz 1971, s. 102, 110). Zewnętrzny wymiar egzemplarzy z Rusi najprawdopodobniej mieści się w granicach od 1,8 do 2,5 mm. Według obserwacji L. Rauhuta (1971, s. 473), na Mazowszu kabłączki „małe” (zapewne o średnicy zewnętrznej do około $20 \mathrm{~mm}$ ) należy datować na XI w. i pierwsze dwa dziesięciolecia XII w., okazy „średnie” (zapewne o średnicy zewnętrznej do około $50 \mathrm{~mm}$ ) - od końca XI do 3 ćwierci XII w. Z kolei na cmentarzyskach z międzyrzecza wschodniego odcinka dolnego Bugu i górnej Narwi kabłączki podtypu III.1, tj. o średnicy zewnętrznej poniżej $20 \mathrm{~mm}$, odkryto w obiektach datowanych od ostatniej tercji XI w. do 1 ćwierci XII w. Egzemplarze podtypu III.2, tj. o średnicy zewnętrznej od 20 do $27 \mathrm{~mm}$, znaleziono w obiektach z okresu od ostatniej tercji XI w. do końca XIII w. (Dzik 2015, I, s. 165 oraz II, s. 9-12).

W grobie nr 2 z Rusi odkryto również pozostałość kolii w postaci 10 paciorków, w tym: 2 metalowych, 3 kamiennych i 5 szklanych (tabela 3 ). 
Tabela 3. Zabytki z grobów na cmentarzyskach badanych przez L. de Fleury’ego

Table 3. Artifacts from graves investigated by L. de Fleury

\begin{tabular}{|c|c|c|c|c|c|c|c|c|c|c|c|}
\hline \multirow[b]{2}{*}{ 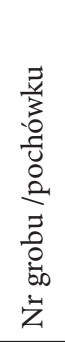 } & \multirow[b]{2}{*}{ 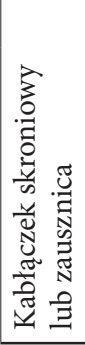 } & \multicolumn{3}{|c|}{ Paciorek } & \multirow[b]{2}{*}{ 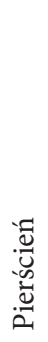 } & \multirow[b]{2}{*}{ 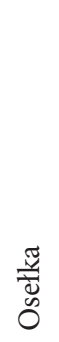 } & \multirow[b]{2}{*}{ 溚 } & \multirow[b]{2}{*}{ 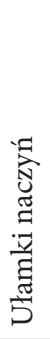 } & \multirow[b]{2}{*}{ 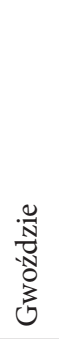 } & \multirow[b]{2}{*}{ 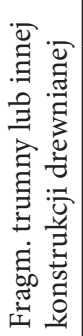 } & \multirow[b]{2}{*}{ 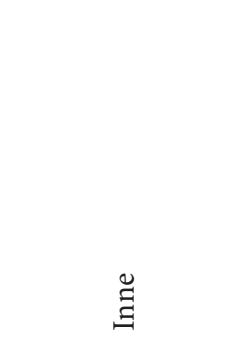 } \\
\hline & & 音 & $\frac{\widehat{J}}{\frac{\tilde{J}}{\mathbb{N}}}$ & 氖 & & & & & & & \\
\hline \multicolumn{12}{|c|}{ Kokoszki, stan. 1} \\
\hline 1 & & & & & & & 1 & + & 2 & & „klamra” \\
\hline $2,2 \mathrm{a}$ & $1 ?$ & & & & 1 & & & + & $\geq 2$ & & \\
\hline 3 & & & & & & & & + & $\geq 2$ & + & \\
\hline \multicolumn{12}{|c|}{ Kotówek (Rostki Małe), stan. 1} \\
\hline 1 & & & & & 1 & & 1 & & 6 & + & $\begin{array}{l}\text { okucia wiadra; } \\
\text { grot włóczni; } \\
\text { przedmiot } \\
\text { nieokreślony }\end{array}$ \\
\hline 2 & & & & & & & & + & & & \\
\hline 3 & & & & & & 1 & & & & & dzwonek \\
\hline \multicolumn{12}{|c|}{ Ruś, stan. 7} \\
\hline 1 & & & & & & & & + & & & \\
\hline 2 & 12 & 2 & 5 & 3 & 1 & & & & 2 & & \\
\hline 3 & & & & & & & & 1 & & & przęślik \\
\hline 4 & & & & & & 1 & & + & & & \\
\hline 5 & & & & & & & & + & & & \\
\hline $6 ?$ & & & & & & 1 & 1 & & & & $\begin{array}{c}\text { sprzączka; } \\
\text { przedmiot srebrny }\end{array}$ \\
\hline $6 \mathrm{a}$ & & & & & & & 1 & & & & \\
\hline $6 \mathrm{~b}$ & & & & & & & & 1 & 2 & + & \\
\hline $6 c$ & & & & & & 1 & 1 & + & 2 & & $\begin{array}{l}\text { pochewka noża; } \\
\text { nożyce; krzesiwo; } \\
2 \text { misy }\end{array}$ \\
\hline \multicolumn{12}{|l|}{$7 \mathrm{a}$} \\
\hline $7 \mathrm{~b}$ & & & & & & 1 & 2 & + & & $+?$ & $\begin{array}{c}\text { fragment } \\
\text { pochewki noża }\end{array}$ \\
\hline 8 & & & & & & & & + & & & \\
\hline 9 & & & & & & & & + & & & \\
\hline 10 & & & & & & & & + & & & \\
\hline 11 & & & & & & & & & & & zapinka \\
\hline 12 & & & & & & & & & & & \\
\hline
\end{tabular}


Srebrny paciorek guzowaty prawdopodobnie pokryty był ornamentem z granulek, a nie z tordowanego drutu, jak napisał L. de Fleury, bowiem egzemplarze ozdobione tym ostatnim nie są znane. Ponadto granulacją ozdobiona jest podana przez autora analogia, uznana przez niego za niemal identyczną, czyli paciorek z Ruśca ${ }^{21}$. Paciorki guzowate ze srebra należą do ozdób znanych $\mathrm{z}$ wielu znalezisk na ziemiach polskich, szczególnie licznych w Wielkopolsce i Polsce centralnej (Kóčka-Krenz 1993, mapa 41). Mniej częste ich odkrycia odnotowano też na Białorusi i Ukrainie, jak na przykład w niedawno opublikowanym skarbie z lat trzydziestych XI w., z miejscowości Dziahciany w obw. mińskim (Sidorovič, Râbceva, Plavinskij 2015, s. 154, 175, ryc. 7: 13, 14). Chronologia paciorków guzowatych nie była przedmiotem pogłębionych analiz. Trafny wydaje się pogląd, iż ozdoby te są śladem wpływów złotnictwa wielkomorawskiego, na co wskazuje zarówno ich stylistyka, jak i technika wykonania (Duczko 2016, s. 138-139). Najstarszym poświadczeniem obecności takich ozdób na ziemiach polskich wydaje się skarb z Lublina-Czechowa, z ostatniej ćwierci IX w. (Frühmittelalterliche... 2013, s. 88-109 - tam dalsza literatura). W omówieniu paciorków guzowatych autorstwa Hanny Kóčki-Krenz jako najmłodsze wskazane zostały zabytki z sześciu cmentarzysk w środkowej Polsce i na Mazowszu, to jest w Brzegu i Poddębicach w pow. poddębickim, Nieporęcie, pow. legionowski, Starogrodzie, pow. miński, Surażu, pow. białostocki i Tańsku-Przedborach, pow. mławski (Kóčka-Krenz 1993, s. 96). Większość z tych znalezisk nie może być obecnie precyzyjnie datowana, a niektóre są jednoznacznie umiejscawiane w 2 poł. XI w. (Tańsk-Przedbory; Rauhut, Długopolska 1973, s. 435-436). Jedynym zabytkiem datowanym od połowy XII w. jest egzemplarz z cmentarzyska w Starogrodzie, funkcjonującego, według autorów badań, od połowy XII do połowy XIII w. (Bronicka-Rauhut, Rauhut 1977, s. 84). Na tej podstawie wydaje się zasadnym przyjęcie, iż paciorki guzowate są charakterystyczne dla okresu od ostatniej ćwierci IX do 1 poł. XII w., z dopuszczeniem sporadycznej obecności w zespołach z 2 poł. XII w.

Drugi z metalowych paciorków z grobu nr 2 w Rusi, odkryty blisko paciorków szklanych, to kulisty egzemplarz pokryty granulacją (ryc. $3 \mathrm{~m}$ ). Rysunek i opis

${ }^{21}$ Paciorek ten miał pochodzić z grobu (z obstawą?; ros. гробница с отделением) w Ruścu blisko Warszawy i znajdować się w kolekcji Józefa Przyborowskiego. L. de Fleury opisał znalezisko z Ruśca następująco: „Jest to paciorek beczułkowaty, podzielony na dwie równe części podwójnym kołnierzem (гуртиком) і mający z obu końców podobne kołnierze. Ta beczułka [...] także jest pokryta guzkami, które u podstawy są otoczone kołnierzem, i różni się od naszego fragmentu tylko tym, że każdy guzek jest w szczycie dziurawy" (RONA IIMK, zb. 1, 1-1890/28, k. 8r). W zbiorach Państwowego Muzeum Archeologicznego (dalej: PMA) w Warszawie, do którego trafiły zabytki z kolekcji J. Przyborowskiego, znajduje się paciorek z Ruśca, ale w pow. bełchatowskim (dawniej pow. łaski; PMA/V/1152: 1, nr kat. 7 - na karcie brak informacji o kolekcji, z której pochodzi ten okaz). Odpowiada on opisowi L. de Fleury'ego, stąd wydaje się prawdopodobne - choć jest to tylko hipoteza - że wiadomość de Fleury nie dotyczyła paciorka z leżącego blisko Warszawy Ruśca w pow. pruszkowskim (o cmentarzysku wczesnośredniowiecznym na terenie tej wsi skądinąd nic nie wiadomo), ale właśnie Ruśca w pow. bełchatowskim (na temat innych znalezisk z tego stanowiska: Musianowicz [1951-1952] 1952, s. 347, 348 - tam też dalsza literatura; Kufel-Dzierzgowska 1975, ryc. 1: 24). Autor dziękuje kustoszce Działu Średniowiecza i Archeologii Czasów Nowożytnych PMA, mgr Magdalenie Ruszkowskiej, za pomoc w uzyskaniu informacji na temat paciorka z Ruśca. 
zabytku nie pozwalają na jednoznaczne rozstrzygnięcie, czy jego korpus wykonany był $\mathrm{z}$ blachy, czy też z drutu. Bardziej prawdopodobna jest druga $\mathrm{z}$ wymienionych możliwości, ze względu na obecność wyraźnych pierścieni wzmacniających krawędzie otworów, a także luźne rozmieszczenie granulek (por. Dzik 2015, I, s. 190 - opis paciorków podgrupy I.2). Paciorki blaszane, które były używane jako część kolii, to tzw. paciorki malinowate, gęsto pokryte regularnymi rzędami ziaren (np. egzemplarz ze Skiw Małych pow. siemiatycki, z grobu nr 4; Dziedzictwo 2006, s. 100). Nieregularna granulacja jest spotykana na paciorkach dętych, ale tych nawlekanych na kabłąk zausznic (Dzik 2015, I, 168, tabela 13 - paciorki odmiany c). Te są jednak wyraźnie mniejsze od rekonstruowanych rozmiarów egzemplarza z Rusi, które z kolei odpowiadają paciorkom ażurowym koszyczkowatym, używanym w koliach. Kilkanaście takich ozdób odkryto na cmentarzyskach dorzeczy górnej Narwi i wschodniego odcinka dolnego Bugu (K. Bieńkowska 2005, s. 127, tabl. VII 9; Dzik 2015, I, s. 190, tabela 15; Olczak, Krasnodębski 2019, s. 69, ryc. 5.13; Radzikowska 2019, s. 137, ryc. 7.10). Znane są też z kilku odkryć ze wschodniego Mazowsza (np. Święck-Strumiany, pow. wysokomazowiecki; D. Jaskanis 2008, s. 189-190). Na Starym Mazowszu analogiczny paciorek odkryto w zaledwie jednym grobie, w Tańsku-Przedborach, pow. mławski (Rauhut, Długopolska 1973, s. 396, tabl. IIIe). Na podstawie znalezisk z cmentarzysk z wymienionych regionów paciorek $\mathrm{z}$ granulacją można datować od 2 poł. XI w. do XIII w.

Trzy paciorki z grobu nr $2 \mathrm{w}$ Rusi - fasetowane, barwy jasnofioletowej, to zapewne wyroby z fluorytu lub ametystu. Według L. Rauhuta, na cmentarzyskach z Mazowsza takie ozdoby znane są głównie z grobów z 1 poł. XII w., a sporadycznie odkrywane są także w obiektach z ostatniej ćwierci XI w. i 3 ćwierci XII w. (Rauhut 1971, s. 466, 467, 473). Z kolei na cmentarzyskach w międzyrzeczu Bugu i górnej Narwi paciorki kamienne należą do znalezisk wyjątkowo rzadkich (Dzik 2015, I, s. 194). Dwa egzemplarze z Rusi to wyroby elipsoidalne z czworokątnymi fasetami, w przekroju poprzecznym prawdopodobnie oktagonalne (ryc. 3g, h). Nie mają one analogii wśród paciorków kamiennych o znanej formie, odkrytych na Mazowszu i obecnym Podlasiu. Zbliżone ozdoby, ale wykonane z karneolu i kryształu górskiego, znaleziono m.in. na cmentarzysku w Bodzi, pow. włocławski (groby nr E61, E877, D171; koniec X-1 tercja XI w.; Czech-Błońska 2016). Trzeci egzemplarz z Rusi, o formie dwunasto- lub czternastościanu (ryc. 3i) ma bliskie analogie m.in. w Starym Łączynie, pow. mławski (4 egzemplarze z fluorytu, z grobu nr 9; 1-3 ćwierć XII w.; Rauhut, Długopolska 1972, s. 390, tabl. III h), w Płocku-Podolszycach ( 1 egzemplarz ametystowy z grobu nr 16; połowa XI-1 ćwierć XII w.; Kordala 1992, s. 27, 45, tabl. XIV 6) oraz w Kałdusie (egzemplarze z fluorytu w grobach nr 117/01, 141/01; połowa XII-XII/XIII w.; Bojarski i in. 2010, s. 474, 482, tabl. 28: 2a; 34: 5b).

Pięć paciorków szklanych dwustożkowatych z grobu nr 2 w Rusi to egzemplarze o licznych analogiach na cmentarzyskach Mazowsza i międzyrzecza Bugu i górnej Narwi (Kordala 2006, s. 161-163; Dzik 2015, I, s. 178-187). Trzy z nich to prawdopodobnie wyroby barwy żółtej, dwa - fioletowej. Te ostatnie są wyraźnie rzadziej odnotowywane we wspomnianych regionach. Na podstawie analizy współwystępo- 
wania zabytków na cmentarzyskach w międzyrzeczu Bugu i górnej Narwi ustalono, że paciorki fioletowe wchodziły w skład zespołów grobowych z okresu od 2 ćwierci XII w. do połowy XIII w. (Dzik 2015, II, 17, tabl. 5).

Przedmiot z grobu nr 3 w Kotówku (Rostkach Małych), określony jako mały dzwonek, to najprawdopodobniej zawieszka dzwoneczkowata. Takie zabytki, wykonane ze stopu miedzi, zwykle o formie zamkniętej, zbliżonej do kulistej, z otworem $\mathrm{w}$ dolnej części, są znane - choć w niewielkiej liczbie - z cmentarzysk z sąsiednich regionów. Pojedyncze egzemplarze odkryto w: Czarnej Wielkiej, pow. siemiatycki (Dzik 2014a, s. 178, ryc. 70: 1), Grzebsku, pow. mławski (Zawadzka-Antosik 1973, s. 479, tabl. IVd), Pokrzywnicy Wielkiej, pow. nidzicki (Rauhut, Długopolska 1971, s. 314), Surażu (Bieńkowska 2005, s. 127, tabl. VII 1) i Warszawie-Wilanowie (Solecki 2018, s. 161, ryc. 22H). Cztery zawieszki znaleziono na cmentarzysku w Czersku, pow. piaseczyński (Bronicka-Rauhut 1998, s. 30-31), osiem w Święcku-Strumianach (D. Jaskanis 2008, s. 218-219), a około 40 sztuk - w Równinie Dolnej pow. kętrzyński (Odoj 1958). Najstarsze z tych znalezisk datowane są na 1 ćwierć i połowę XII w. (Grzebsk, Pokrzywnica Wielka), najmłodsze zaś na 2 poł. XIV w. (Równina Dolna). Brak danych o formie przedmiotu z Rusi nie pozwala na uściślenie tej chronologii.

Pierścionki odkryto $\mathrm{w}$ trzech grobach, po jednym na każdym cmentarzysku (tabela 3). Wszystkie zostały opisane jako egzemplarze srebrne, wite, z końcami wolnymi. Dokładniej technikę ich wykonania można rekonstruować na podstawie rysunków dwóch z nich (ryc. 2j; 3c). Pierścionek z grobu nr 1 w Kotówku (Rostkach Małych), skręcony z gładkich drutów i charakteryzujący się końcami niesklepanymi, ma pod względem tej ostatniej cechy bliskie analogie zarówno na Starym Mazowszu (Tańsk-Przedbory, 1 egzemplarz z grobu nr 15/16 z 2 poł. XI-XI/XII w.; Rauhut, Długopolska 1973, s. 403, tabl. V), Mazowszu południowo-wschodnim (Węgrów, 1 egzemplarz z cmentarzyska; Musianowicz 1960, s. 200, tabl. I: 6), jak i w międzyrzeczu Bugu i górnej Narwi (Czarna Wielka, 2 egzemplarze spoza zespołów zwartych; Bieńkowska, Dzik, Piasecka 2013, tabl. CXXXV: ar 48, 2; Dzik 2015, I, tabl. IX 6). Egzemplarz z grobu nr 2 w Rusi, wykonany z kilku skręconych ze sobą par(?) drutów, ma dość liczne analogie na ziemiach polskich datowane w zdecydowanej większości na XI i XII w. (Kóčka-Krenz 1993, s. 117). W sąsiadujących regionach podobne pierścionki odkryto na cmentarzyskach w: Orszymowicach (obecnie Rostkowo-Orszymowice, pow. płocki; Tarczyński 1901, tabl. XI 3; Banasiewicz 2006, poz. 298), Czekanowie pow. sokołowski (Schätze... 2011, s. 96, poz. 137), Korzeniówce Małej, Narojkach i prawdopodobnie Czarnej Wielkiej pow. siemiatycki (Musianowicz 1960, tabl. VIII 6; Długopolska 1991, tabl. I 6; Dzik 2015, I, s. 212, tabela 18 [pierścionki podgrupy II.3]; tenże 2017, s. 193, ryc. 7: 10).

Sprzączkę odkryto w co najmniej jednym grobie, nr 6 (?) z Rusi (ryc. 4l). Na podstawie rysunku tego przedmiotu, jego proporcji i prawdopodobnego surowca (stop miedzi), a także znanych form sprzączek, można go zaliczyć do egzemplarzy prostokątnych, dwuczłonowych, o długości większej od szerokości. Jeśli ta identyfikacja jest prawidłowa, to na cmentarzyskach $\mathrm{z}$ najbliższych regionów do zabytku tego byłaby analogia w Bacikach Dalszych, pow. siemiatycki, z pochówku pochodzącego najprawdopodobniej z ostatniej tercji XI w. (Dzik 2015, I, s. 48, 219, tabl. XX 14). 
Kolejne analogie, datowane w zdecydowanej większości na XI w., znane są głównie z Europy Wschodniej (Dzik 2015, I, s. 222 - tam dalsza literatura).

Niewykluczone, że pozostałością sprzączki była też bliżej nieopisana „żelazna klamra” z grobu nr 1 w Kokoszkach. Trudno też określić, czym dokładnie był zabytek z grobu nr $11 \mathrm{w}$ Rusi, określony przez L. de Fleury'ego jako brązowa, pozbawiona igły zapinka. Najbardziej prawdopodobne wydaje się, że mogła to być zapinka podkowiasta. Tego rodzaju zabytki znane są z Mazowsza i z międzyrzecza Bugu i górnej Narwi (Jończyk 2013, s. 41-44, ryc. 16), w tym z cmentarzysk (dwa egzemplarze z Czarnej Wielkiej [Dzik 2015, I, s. 67, tabl. IX 1; tenże 2017, s. 188, poz. 29, ryc. 2: 29; 6: 1], jeden egzemplarz ze Święcka-Strumian [D. Jaskanis 2008, s. 227, tabl. CLXII 19]). Liczne ich odkrycia pochodzą natomiast $z$ sąsiednich ziem bałtyckich (Jończyk 2013, s. 47 nn.). Nie można jednak wykluczyć, że był to przedmiot o innej formie, a nawet $\mathrm{z}$ innego okresu, znajdujący się na złożu wtórnym (por. Kordala 2006, s. 206).

Jedyny element uzbrojenia odkryty przez L. de Fleury'ego, to grot broni drzewcowej z grobu nr 1 w Kotówku (Rostkach Małych). Kolejne militaria, w tym dłuższy grot i żeleźca toporów, miały być znajdowane przy wybieraniu kamieni na cmentarzysku w Rusi, brak jednak bliższych informacji na ich temat. Grot z Kotówka opisany został przez odkrywcę jako duży, jednak określenie jego rzeczywistych rozmiarów nie jest obecnie możliwe. Na podstawie rysunku zabytku kształt liścia wydaje się odpowiadać grotom typu IV według Andrzeja Nadolskiego (1954, s. 54) oraz typu IV w klasyfikacji Anatolija Kirpicznikowa, datowanego na XI-XII w. (Kirpičnikov 1966, s. 14-15, ryc. 1). Na cmentarzyskach z grobami w obudowach kamiennych groty tego typu odkryto między innymi w: Dołubowie, pow. siemiatycki, w grobie nr 16 z 2 ćwierci XII - połowy XIII w. (Dzik 2015, I, tabela 23; II, s. 117); Grzebsku, w grobie nr 3 datowanym od XI/XII w. do połowy XII w. (Zawadzka-Antosik 1973, s. 468); Łączynie Starym, w grobie nr 28 z 4 ćwierci XI-XI/XII w. (Rauhut, Długopolska 1972, s. 349, tabl. Xc; por. też Kordala 2006, tabl. 25 - tam informacje o kolejnych egzemplarzach z sześciu cmentarzysk). Na podstawie dostępnych danych o położeniu grotu z Kotówka można przyjąć, iż odkryto go po prawej stronie szkieletu, blisko kości stóp. Układ ten jest typowy dla cmentarzysk znad górnego Orzyca, w innych regionach Mazowsza i w międzyrzeczu Bugu i górnej Narwi jest rzadszy (Kościelecki 2000, s. 66; por. Dzik 2015, I, s. 231).

Zabytki zaliczane do kategorii narzędzi odkryto przy dziewięciu lub dziesięciu zmarłych (41\% lub 45\% wszystkich pochówków), a jeśli uwzględnić gwoździe - przy trzynastu (59\%). Noże znaleziono w pięciu lub sześciu pochówkach (22\% lub 27\%; nie jest pewne, do którego $\mathrm{z}$ zespołów należał $1 \mathrm{z}$ egzemplarzy przypisanych do grobu nr 6 w Rusi - por. uwagi do tego obiektu). W jednym przypadku - pochówku nr $7 \mathrm{~b}$ w Rusi- przy zmarłym odkryto 2 egzemplarze, jeden przy czaszce, umieszczony w pochewce, drugi przy kościach nóg (brak dokładnej lokalizacji). Pochówki z dwoma nożami znane są zarówno z północnego Mazowsza, jak i z międzyrzecza Bugu i górnej Narwi. Na obu tych obszarach odnotowywano też, choć sporadycznie, pochówki z nożem w pobliżu czaszki (Kordala 2006, s. 176, tabela 36; Dzik 2015, I, s. 251-252, ryc. 83). W kolejnych dwóch pochówkach, w przypadku których 
znamy położenie noży (nr 1 w Kotówku i nr 6c w Rusi), noże odkryto w okolicy pasa zmarłego, a więc w położeniu typowym dla tej kategorii znalezisk.

Cztery noże przedstawiono na zachowanych rycinach, stąd możliwe jest określenie ich kształtu. Miały one tylec prosty i trzpień w formie kolca jedno- lub dwustronnie wyodrębnionego. Jeden egzemplarz, z grobu nr 1 w Kotówku (Rostkach Małych), wyróżniał się sztychem ściętym górą prosto lub lekko łukowato i głownią lekko rozszerzoną od strony sztychu; określony został jako duży (ryc. 2k). Noże o tej formie, w klasyfikacji Jacka Wrzesińskiego określone jako typ VI, odmiana a (Wrzesiński 2000, s. 99-100), należą do rzadziej spotykanych. W najbliższych regionach odkryto je między innymi w: Blichowie, pow. płocki (grób nr 4, połowa XI - początek XII w.; Kordala 2006, s. 39, 178; fotografia w: Banasiewicz 2006, poz. 205), Brześciu Kujawskim, pow. włocławski (grób nr 11, połowa XI - 1 ćwierć XII w.; Kaszewscy 1971, tabl. III 5), Pokrzywnicy Wielkiej (grób nr 12, koniec 1 poł. XII w.; Rauhut, Długopolska 1971, s. 305, 347, tabl. IIIg) i Skiwach Małych (grób nr 4, 3 tercja XI - połowa lub 2 tercja XII w.; A.M. Bieńkowska 2010, ryc. 4: 17; Dzik 2015, I, s. 137, 253 - tam też dalsze przykłady i literatura). Na podstawie analogii zabytek można datować na okres od połowy XI w. do 3 ćwierci XII w.

Co najmniej dwa noże, $\mathrm{z}$ dwóch grobów w Rusi, znajdowały się w pochewkach drewnianej lub skórzanej (pochówek nr $7 \mathrm{~b}$ ) oraz drewnianej z żelaznym trzewikiem i okuciami krawędzi (pochówek nr 6c). Na wczesnośredniowiecznych cmentarzyskach Mazowsza i obecnego Podlasia znaleziska pochewek noży są dość częste, szczególnie na Mazowszu Północnym (Kordala 2006, s. 178-182). Żelazny trzewik przedstawiony na ryc. $4 \mathrm{i}$ charakteryzował się prostą krawędzią od strony tylca noża i łukowatą od strony jego ostrza. Wydaje się, że trzecia krawędź ozdobiona była trzema wcięciami. Swoisty ornament, w postaci siedmiu wyciętych otworów, zdobił też krawędź prostą. Pod względem kształtu okucie to nosi cechy typów III i IV w klasyfikacji Władysława Łęgi (1930, s. 231), stworzonej na podstawie znalezisk okuć brązowych. Egzemplarz z Rusi wyróżnia obecność okuć krawędzi pochewki, być może pierwotnie spiętych u końców dodatkową obręczą, a także surowiec. Żelazne okucia pochewek noży są bowiem zdecydowanie rzadsze od brązowych w materiałach wczesnośredniowiecznych. W najbliższych regionach odkryto je m.in. na cmentarzyskach w Rybałtach, pow. siemiatycki (Rauhut, Długopolska 1974, s. 353) oraz Święcku-Strumianach (D. Jaskanis 2008, s. 374). Pod względem formy oba nie stanowią jednak analogii do egzemplarza z Rusi. Zbliżone okucia krawędzi pochewki, do tego także wykonane $\mathrm{z}$ żelaza, znane są z zespołów późnośredniowiecznych, na przykład z Wrocławia (Wieczorek-Kańczura, Szajt 2018, ryc. 7), a także z cmentarzyska z grobami z konstrukcjami kamiennymi w Kylälahti Kalmistomäki, na północnym nadbrzeżu jeziora Ładoga (Karelia, Rosja; Bel’skij 2012, s. 155 , ryc. $64: 2$ b; 119: 5).

Znalezione w pochówku nr 6c w Rusi krzesiwo ogniwkowe, charakteryzujące się prostokątnym kształtem i półkolistymi wrębami otworu, ma analogie pod względem tych cech w: Czarnej Wielkiej (grób nr 204, 3 tercja XI-XIII w.; Bieńkowska, Dzik, Piasecka 2013, s. 95, tabl. CIII 2), Niewiadomej (cmentarzysko z XII - połowy XIII w.; Miśkiewiczowa 1996, tabl. XXII 8, XXIII 5), Smolugach, pow. siemiatycki 
(grób nr 72, koniec XII - połowa XIII w.; Dzik 2015, I, tabela 26, poz. 59; II, s. 122, ryc. 43), Starym Łączynie (pochówek nr 4b, 2 poł. XII w.; Rauhut, Długopolska 1972, s. 326, tabl. Ij). Żadne ze znalezisk znanych autorowi nie ma jednak prostokątnych wrębów na krótszych krawędziach, wyróżniających egzemplarz z Rusi.

Z pochówku nr 6c pochodzą również nożyce kabłąkowe (ryc. 4f). Z przyległych regionów znane są zaledwie dwa przypadki odkrycia nożyc $w$ grobach, oba z północnego Mazowsza. Odkryto je w Grzebsku (grób nr 3, XI/XII - połowa XII w.; Zawadzka-Antosik 1973, s. 469, tabl. IId) oraz Małachowie, pow. płocki (grób nr 4, XI/XII-XII w.; Kordala 2006, tabela 8). Terytorialnie bliskie analogie znalezisk nożyc jako wyposażenia grobowego znane są też z Brześcia Kujawskiego (grób nr 172, połowa XI - 1 ćwierć XII w.; Kaszewscy 1971, s. 397, tabl. VIII 18) i Bodzi, pow. włocławski (grób E864/I, 1 tercja XI w.; T. Sawicki 2016, s. 239, ryc. 3.8.5: 6 - tam dalsze przykłady; na temat nożyc w pochówkach por. też Wadyl 2019, s. 195-198). Na podstawie znanych i dobrze datowanych analogii wydaje się, że we wczesnym średniowieczu w najbliższych regionach przedmioty te składano w grobach od XI do połowy XII w. W szerszym kontekście terytorialnym, jako wyposażenie zmarłych znane są także z zespołów późnośredniowiecznych i wczesnonowożytnych (np. Kvâtkovskaâ 1998, s. 125-126; J. Sawicki 2015, s. 74-75 - tam dalsza literatura).

Osełki odkryto w czterech grobach. Co najmniej jedną z nich, z pochówku nr $6 \mathrm{c}$ w Rusi, odkryto na wysokości pasa zmarłego. W odniesieniu do trzech egzemplarzy, z grobów nry 6 i 7 w Rusi, podano informację, iż miały one otwór, służący do ich przytroczenia. Jedną osełkę, z grobu nr 3 z Kotówka (Rostek Małych), L. de Fleury określił, jako wykonaną z piaskowca. Niewykluczone, że z tego samego surowca były zrobione dwa egzemplarze z grobu $\mathrm{nr} 6 \mathrm{w}$ Rusi, skoro na rysunku przedstawiono je jako barwy jasnobeżowej (ryc. 4a, b, e). Osełki, w tym wykonane z piaskowca i zaopatrzone w otwór, są odnotowywane na cmentarzyskach wczesnośredniowiecznych Mazowsza oraz międzyrzecza Bugu i górnej Narwi (Kordala 2006, s. 185-186, tabela 39; Dzik 2015, I, s. 255-256, tabela 29). Na obecnym etapie badań nie stanowią one wyznacznika chronologicznego.

Przęślik z grobu $\mathrm{nr} 3 \mathrm{w}$ Rusi prawdopodobnie był wykonany z różowego łupku owruckiego. Na północnym Mazowszu egzemplarze z tego surowca odkryto w pięciu grobach, na tyluż cmentarzyskach (Kordala 2006, s. 188, tabl. 40). Liczniejsze znaleziska pochodzą z cmentarzysk wschodniego Mazowsza i z dorzecza wschodniego odcinka dolnego Bugu (np. Miśkiewiczowa 1996, s. 35; D. Jaskanis 2008, s. 241-243; Dzik 2015, I, s. 256-258). Ze względu na dość szerokie datowanie - od $\mathrm{X}$ do początku XIV w. - i małą różnorodność form, nie stanowią one dobrego wyznacznika chronologicznego (por. Pavlenko 2010, s. 163 - tam dalsza literatura).

W siedmiu lub ośmiu pochówkach (32\% lub 36\% wszystkich) odkryto gwoździe żelazne. Wątpliwość co do liczby zespołów związana jest $\mathrm{z}$ sumarycznym podaniem informacji o zabytkach z grobów nr 2 i 2a z Kokoszek. Niepewność dotyczy także liczby gwoździ znalezionych w grobach $\mathrm{nr}$ 2, 2a i 3 z tego stanowiska. Łącznie na opisywanych tu trzech cmentarzyskach odkryto co najmniej 18 gwoździ, z których 11 przedstawiono na rycinach. Wszystkie miały czworokątne przekroje, były niewątpliwie kute, różniły się jednak sposobem uformowania łepków i długością. Trzy 
egzemplarze z grobu nr 6 w Rusi miały łepek niewyodrębniony lub słabo wyodrębniony, uformowany przez lekkie sklepanie poprzeczne, tj. prostopadłe do osi trzpienia, tępego końca (ryc. 4n-p). Osiem gwoździ, z grobów nr 1 w Kotówku (Rostkach Małych) i nr 2 w Rusi, miało łepek jednostronny, płaski, wykonany przez zagięcie tępego końca, w niektórych przypadkach niewątpliwie sklepanego wzdłużnie, tj. równolegle do osi trzpienia. Okazy obu form mieszczą się odpowiednio w grupach I i II, wyróżnionych na podstawie licznych znalezisk z cmentarzysk Wysoczyzny Drohiczyńskiej (Dzik 2015, I, s. 239-242). Podobnie jak w przypadku innych znalezisk, L. de Fleury nie podał rozmiarów gwoździ. Niewykluczone jednak, że niektóre z nich przedstawił w skali 1:1. Dotyczyć to może egzemplarzy grupy II z grobu nr $1 \mathrm{w}$ Kotówku, których długość na rycinach wynosi, w przybliżeniu: $3,5 \mathrm{~cm}$ (jeden okaz) i 5-6,5 cm (cztery egzemplarze), a także gwoździ z grobu nr 2 w Rusi, mierzących 6,5 i 7,5 cm (ryc. 2a, b, d, n, o; 3a, b). Długość tych ostatnich zbliżona jest do typowej dla gwoździ z cmentarzysk Wysoczyzny Drohiczyńskiej (Dzik 2015, I, ryc. 81). Egzemplarze z grobu nr $6 \mathrm{w}$ Rusi jako jedyne określono w sprawozdaniu jako duże i bardzo duże, toteż zapewne były większe od pozostałych. Jest to tym bardziej prawdopodobne, że gwoździe grupy I charakteryzuje właśnie znaczna długość, średnio $11 \mathrm{~cm}$ (Dzik 2015, I, s. 240, ryc. 81). Z tej też przyczyny wydaje się, że na rycinie nie zostały przedstawione w skali 1:1 (ryc. $4 \mathrm{n}-\mathrm{p}$ ).

W co najmniej czterech grobach odkryto po dwa gwoździe, w jednym - sześć sztuk (tabela 3). W odniesieniu do pięciu zespołów znane jest położenie tej kategorii zabytków względem szkieletów. Na tej podstawie można przyjąć, że w przypadku dwóch egzemplarzy istniała reguła, iż jeden znajdował się blisko czaszki, drugi blisko kości stóp. W grobie nr 1 z Kotówka (Rostek Małych), w którym odkryto sześć gwoździ, dwa zostały odkryte przy czaszce, dwa przy kościach stóp i dwa pośrodku szkieletu. Odnotowany układ zapewne związany jest ze sposobem przybijania wieka trumien lub innych drewnianych konstrukcji osłaniających ciało zmarłego (na temat hipotez dotyczących funkcji gwoździ w grobach por. D. Jaskanis 2008, s. 237-240; Dzik 2015, I, s. 243-244, II, s. 153-155 - tam dalsza literatura).

$\mathrm{Na}$ ślady drewna zwrócono uwagę $\mathrm{w}$ trzech grobach zawierających gwoździe (tabela 3). W każdym z nich L. de Fleury określił drewno jako dębowe. W dwóch przypadkach - grobu nr 1 w Kokoszkach i pochówku nr 6b w Rusi - odkryto je przy czaszkach, a w jednym grobie, nr 1 w Kotówku (Rostkach Małych) - na całej długości szkieletu. W odniesieniu do tego ostatniego autor badań opisał drewno jako zwęglone. Taka możliwość jest oczywiście do przyjęcia, ale nie można też wykluczyć, iż de Fleury, nie mając doświadczenia z materiałem zabytkowym, mógł mieć trudność w odróżnieniu drewna sczerniałego od zwęglonego. Wskazują na to jego wątpliwości w odniesieniu do rozkopanego później grobu nr 7 w Rusi, w którym na poziomie pochówku miał znaleźć „węgle lub poczerniałe drewno”.

Pozostałości naczyń, które zostały włożone do grobów najprawdopodobniej w całości, odkryto w dwóch obiektach, w obu z prawej strony szkieletu, „w nogach”, czyli blisko kości piszczelowych lub kości stóp. W Kotówku, w grobie nr 1, znaleziono żelazne elementy wiadra klepkowego (ryc. 2e-i). Jeśli ich wzajemne proporcje na rysunku oddano prawidłowo, to było to naczynie w kształcie ściętego stożka. 
Ze względu na brak wiedzy o rozmiarach kabłąka i obręczy, ustalenie jego pojemności nie jest możliwe. Zaczepy wykonane były z zagiętych prętów; jest to najczęściej stosowane rozwiązanie w sąsiednich regionach (por. Kordala 2006, s. 192; Dzik 2015, I, 265). Rzadsze jest zdobienie kabłąka przez tordowanie. Ma ono analogie na Mazowszu, w znaleziskach z cmentarzysk w: Kościeszach, pow. pułtuski (grób nr 3; Marciniak 1959, s. 64, ryc. 3), Orszymowicach (cmentarzysko z połowy XI połowy XII w.; Rutkowski [1906] 1907, tabl. V), Pokrzywnicy Wielkiej (grób nr 13, 2 ćwierć XII w.; Rauhut, Długopolska 1971, s. 307, tabl. IVc), Turowie, pow. płocki (dwa egzemplarze z cmentarzyska z połowy XI - połowy XII w.; Tarczyński 1900, s. 20, 21) i Żukowie, pow. płoński (grób nr 22, połowa XI - 1 ćwierć XII w.; Dzik 2006, s. 36-37, ryc. 55: 1). Warto zaznaczyć, że tylko dwa egzemplarze, z Kościesz i Pokrzywnicy, były tordowane być może w całości (opublikowana dokumentacja rysunkowa i opisowa nie pozwala na stwierdzenie tego z pewnością), w pozostałych przypadkach $w$ ten sposób ozdobiono jedynie fragmenty przy zakończeniach kabłąka ${ }^{22}$. Niewykluczone, że tordowanie kabłąków może być wyznacznikiem chronologicznym, pozwalającym określić terminus ad quem takich znalezisk na 2 ćwierć XII w. Możliwe jednak, że ich brak z zespołów datowanych po połowie XII w. wynika z niewielkiej liczby pochówków $\mathrm{z}$ wiadrami z tego okresu na Mazowszu (por. Rauhut 1971, s. 473, wykres A). Podsumowanie obecnego stanu badań nad znaleziskami wiader $\mathrm{z}$ cmentarzysk oraz funkcją tych przedmiotów w kontekście sepulkralnym przedstawił niedawno Tomasz Kurasiński, na podstawie materiałów z Polski (Kurasiński 2016), a w szerszym kontekście - Edward Zajkowski (Zajkoŭskì 2018).

$\mathrm{W}$ jednym z pochówków z Rusi, nr 6c, odkryto pozostałości dwóch mis brązowych. Znany jest przybliżony wygląd i wymiary większej z nich - średnica 18-20 cm, wysokość około $5 \mathrm{~cm}$ (ryc. 4r). Brak ornamentu pozwala zaliczyć ją do typu VI według klasyfikacji T. Poklewskiego (1961, s. 25). Zaliczane doń egzemplarze datowane są od X w., a raczej od 2 jego połowy, do XII w.; nieliczne okazy znane są również z XIII stulecia (Müller 2011, s. 252). Z terenu Polski znanych jest ponad 30 wczesnośredniowiecznych grobów, w których odkryto misy (Janowski 2003, tabela 1; tenże 2019, s. 276 - tam dalsza literatura). Jednak odkrycia dwóch mis w jednym zespole należą do bardzo rzadkich. Analogią pod tym względem jest grób nr 609 z Czerska, z końca XI - 1 poł. XII w., w którym złożono zmarłego o niewątpliwie bardzo wysokiej pozycji społecznej (Bronicka-Rauhut 1998, s. 97, ryc. 83; por. Błaszczyk, Stanaszek 2016). Warto zauważyć, że misy znajdowały się $\mathrm{w}$ nim $\mathrm{w}$ podobnym położeniu względem siebie i szkieletu, jak w pochówku z Rusi. Z cmentarzysk z grobami w obudowach kamiennych misy brązowe znane są jedynie z Mazowsza. Trzy egzemplarze odkryto w Pokrzywnicy Wielkiej (groby z 1 poł. XII w.; Długopolska 1973), jeden w Pieńkach-Okopnych (por. w dalszej części tekstu) i jeden prawdopodobnie na cmentarzysku w Blichowie (połowa XI początek XII w.; Szewczuk 2004).

${ }^{22} \mathrm{~W}$ piśmiennictwie pojawiła się błędna informacja o tordowaniu dwóch kabłąków z Turowa na całej ich długości (Janowski, Kurasiński 2008, s. 65). Właściwy opis wraz z fotografiami zabytków zob: Banasiewicz 2006, poz. 106, 107. 


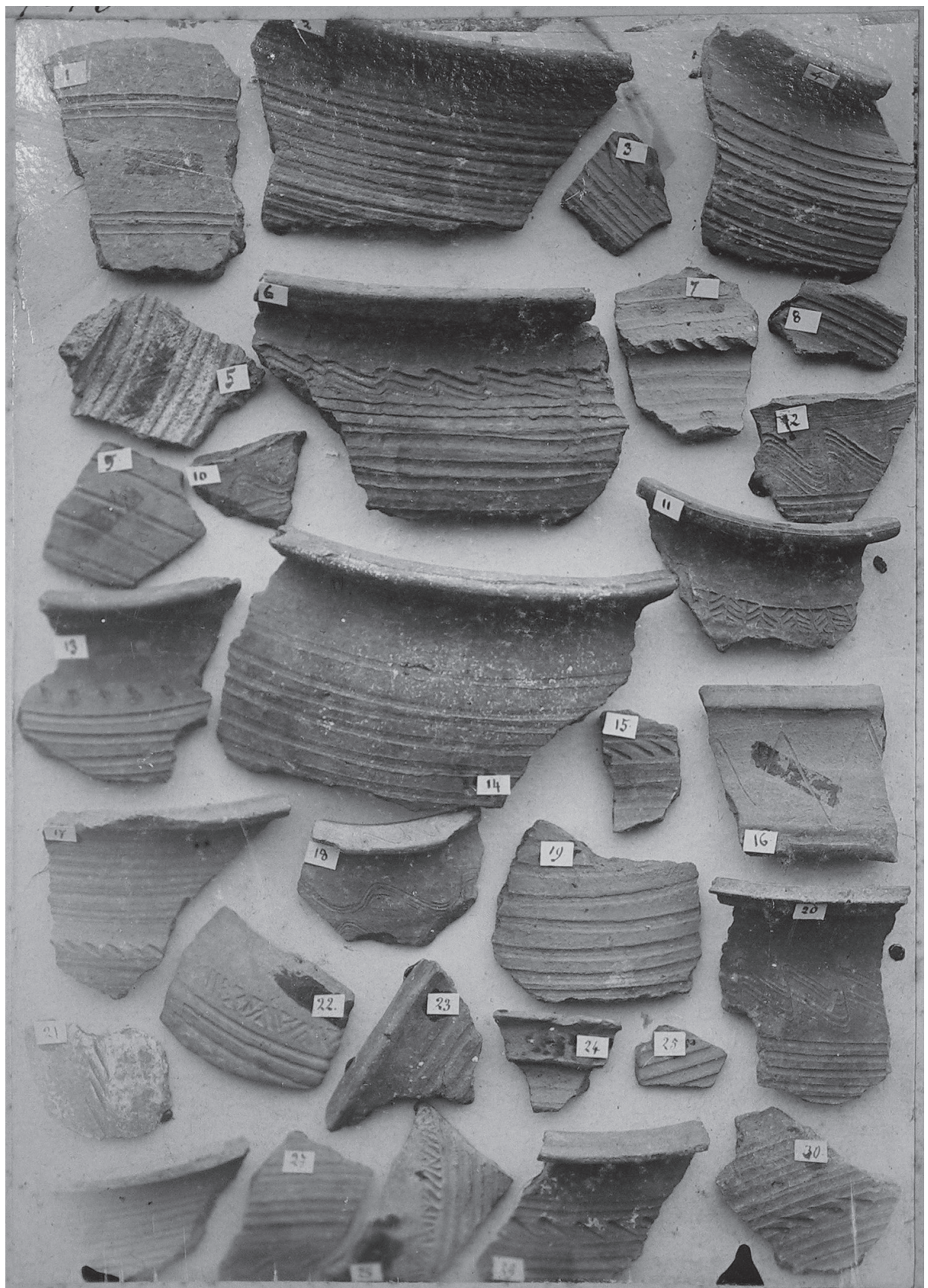

Ryc. 11. Kolekcja L. de Fleury’ego ułamków naczyń glinianych, znalezionych w Wiźnie, pow. łomżyński.

Wg FONA IIMK, sygn. O 754/3

Fig. 11. Louis de Fleury's collection of potsherds found at Wizna, Łomża district.

After FONA IIMK, sign. O 754/3 
Najliczniejszą grupę znalezisk stanowiły ułamki glinianych naczyń, które odnotowano w 12 lub 13 grobach (65\% lub 68\% mogił). Praktycznie nic nie wiadomo o miejscu odkrycia skorup w obrębie obiektów. Niewiele informacji mamy także o ich liczbie i rozmiarach. Niewątpliwie w żadnym przypadku nie składały się one na całe naczynie, gdyż zostałoby to odnotowane. W odniesieniu do jednego obiektu nr 2 lub 2a z Kokoszek - autor sprawozdania podkreślił, że fragmenty stanowiły niemal połowę naczynia i umożliwiły określenie jego średnicy. Można domniemywać, że w pozostałych przypadkach ułamki były mniej reprezentatywne. Przypuszczenie to jest uzasadnione tym bardziej, że w aż siedmiu przypadkach L. de Fleury zapisał, iż skorupy były pojedyncze, nieliczne lub było ich kilka. Liczne odkryto na pewno $\mathrm{w}$ jednym tylko grobie, $\mathrm{nr} 4 \mathrm{z}$ Rusi; pochodziły z jednego, bardzo dużego garnka. $\mathrm{Z}$ kolei pochówek nr $7 \mathrm{~b}$ w Rusi jest jedynym, co do którego wiemy, że znaleziono przy nim ułamki kilku naczyń.

W niemal każdym przypadku L. de Fleury określał ułamki naczyń mianem „typu Burgwall”, przyjmując ten termin za Rudolfem Virchowem (1875, s. 96, 97, 101; por. Trigger 2007, s. 163). Zaznaczył też, że skorupy z grobów są analogiczne do znanych mu z Wizny i innych okolicznych grodzisk (Fleury 1893, s. 333; Zasědanie 1893, s. 366). Zważywszy na obecne datowanie tych stanowisk, można zakładać, że chodzi o wczesnośredniowieczną ceramikę naczyniową z XI-XIII w. Nie jest to jednak rzecz pewna. Na zachowanej fotografii ułamków odkrytych przez L. de Fleury w Wiźnie widoczne są fragmenty naczyń z XI-XIII w., w tym zbliżonych do tzw. typu drohiczyńskiego, ale są też skorupy z wyrobów późnośredniowiecznych (ryc. 11). Obecności tak datowanej ceramiki naczyniowej na cmentarzyskach z grobami w obudowach kamiennych nie można całkowicie wykluczyć.

\section{CHRONOLOGIA CMENTARZYSK}

W literaturze przedmiotu można odnaleźć kilka opinii o datowaniu dwóch nekropoli - w Kotówku (Rostkach Małych) oraz Kokoszkach. Paciorki szklane z pierwszego z nich J. Jaskanis odnosił wstępnie do IX-XI w., zaś L. Rauhut do 2 poł. XII w. (J. Jaskanis 1956b; Rauhut 1971, s. 617, poz. 131; w obu pracach stanowisko pod nazwą Kotowo-Plac). Na 2 poł. XII w. L. Rauhut określił również materiały z prac L. de Fleury'ego na tym stanowisku (s. 618, poz. 133 - tu jako Rostki Małe). Z kolei dla Kokoszek zaproponował on datowanie na XII w. (Rauhut 1971, s. 617, poz. 130). Maria Miśkiewicz przyjęła wnioski L. Rauhuta odnośnie do chronologii Kokoszek, natomiast cmentarzysko w Kotówku (tu jako Kotowo-Plac), kierując się opinią J. Jaskanisa o paciorkach szklanych, odniosła do X-XI w. (Miśkiewiczowa 1982, s. 184). Na tej samej podstawie autorzy badań wykopaliskowych w Kotówku w 1997 r. określili wstępnie chronologię stanowiska na IX-XI w. (Trzciński, Skowron 2006). Pozostali archeolodzy odwoływali się do przytoczonych opinii, bądź zwracali uwagę na brak wystarczających danych do ustalenia chronologii.

Obecnie podstawą do datowania nekropoli są przede wszystkim informacje o formach grobów oraz odkrytych w nich zabytkach ruchomych. Niemal wszystkie 
obiekty rozkopane przez L. de Fleury'ego, to groby w obudowach kamiennych typu I (groby bezjamowe, z brukiem i obstawą), a także II.1 (groby o płytkich jamach, $\mathrm{z}$ brukiem i obstawą), w klasyfikacji wypracowanej na podstawie materiałów z międzyrzecza Bugu i górnej Narwi (Dzik 2015, II, s. 39-46). Na tamtym obszarze groby w obudowach datowane są od ostatniej tercji lub ćwierci XI w. do około połowy XIV w. (Dzik 2015, II, s. 179, 199-200). W okresie do końca XII w. zdecydowanie najczęstszą formą grobów w obudowach były konstrukcje typu I (około $90 \%$ obiektów). Pozostawały one w użyciu do końca XIII w. Przez cały ten czas stosowano także groby typu II.1.

Na Mazowszu groby w obudowach znane są z okresu od połowy XI do XIII w. (Rauhut 1971, s. 465-469; Kordala 2003). Konstrukcje typu I i II.1, odpowiadają grobom odmiany IIa i niektórym obiektom odmiany IIb (groby o najpłytszych jamach) w klasyfikacji L. Rauhuta (1971, s. 456), opracowanej na podstawie materiałów z Mazowsza. Groby o tej formie L. Rauhut datował na okres od XI/XII w. do połowy XII w.

Jeden z grobów, nr 12 w Rusi, prawdopodobnie nie miał konstrukcji kamiennej. Takie obiekty na cmentarzyskach z grobami w obudowach kamiennych pojawiają się od 2 poł. XII w. na Mazowszu a od końca tego stulecia na Wysoczyźnie Drohiczyńskiej.

$\mathrm{Na}$ cmentarzysku w Rusi odkryto jeden pochówek ciałopalny. Istnieje duże prawdopodobieństwo, że kolejne znajdowały się również w Kotówku (Rostkach Małych). Sugerują to wyniki badań z 1997 r., w trakcie których znaleziono przepalone kości (Trzciński, Skowron 2006, s. 197), przy czym nie ma pewności, że pochodziły $\mathrm{z}$ grobu w obudowie kamiennej. Ze względu na ryt pogrzebowy, ale i konstrukcję grobu nr 9 w Rusi, odkrycia te mają kilka analogii nad górnym Orzycem, w obiektach datowanych od 2 poł. XI w. do końca XII lub początku XIII w. (Rauhut 1973, s. 363; por. też Dulinicz 2008 - tu o pochówkach ciałopalnych w Tańsku-Kęsosze, pow. mławski, datowanych na 2 poł. XI - początek XII w.). Z kolei w międzyrzeczu Bugu i górnej Narwi pochówki ciałopalne odkryto na większości szerzej zbadanych cmentarzysk z grobami w obudowach kamiennych. Najstarsze z nich datowane są od ostatniej tercji XI w., najmłodsze ramowo na XII-XIII w. Należy jednak dodać, że dotychczas $\mathrm{w}$ żadnym $\mathrm{z}$ grobów nie znaleziono przedmiotów charakterystycznych dla XIII stulecia, stąd jest bardziej prawdopodobne, że do zaniku zwyczaju palenia zmarłych doszło tutaj już w XII w. (Dzik 2015, II, s. 74-89, 195). Tym samym, pochówek ciałopalny z Rusi i być może kolejny z Kotówka można obecnie datować na 2 poł. XI - XII w.

Na cmentarzysku w Rusi najwięcej przedmiotów pozwalających uściślić datowanie odkryto w grobach nr 2 i 6 . Pierwszy z nich, na podstawie bogatego garnituru ozdób, w tym kabłączków skroniowych typu III.1, można datować między połową XI a 1 ćwiercią XII w. Podobną chronologię mają prawdopodobnie groby nr 3 i 4, skoro sąsiadowały bezpośrednio z grobem $\mathrm{nr} 2$.

Pochówek nr 6c mógł zostać złożony między końcem XI a połową XII w. Wskazują na to przede wszystkim przytoczone analogie grobów z misami, z cmentarzysk $\mathrm{z}$ grobami w obudowach kamiennych oraz z Czerska. Zdaje się to potwierdzać 
również datowanie pochówków z nożycami kabłąkowymi. Zważywszy jednak na formę osełki oraz okucia pochewki noża, nie można wykluczyć, iż był on młodszy i pochodził z 2 poł. XII w. Zasadne jest uznanie, że pozostałe pochówki z grobu $\mathrm{nr} 6$, a także sąsiedni grób nr 5, pochodzą z tego samego okresu co opisany zespół.

$\mathrm{Na}$ cmentarzysku w Kotówku (Rostkach Małych) dość dobre podstawy do datowania stanowi wyposażenie pochówku $\mathrm{nr}$ 1. Jak wynika $\mathrm{z}$ analogii do grotu, noża oraz wiadra, mógł on zostać złożony między połową XI a połową XII w.

W przypadku pozostałych obiektów przesłanki do datowania są słabsze. Wschodnia orientacja niektórych szkieletów, w tym głównie mężczyzn, jest zjawiskiem trwającym do XII w., ale częstym do jego 1 ćwierci lub połowy (Kordala 2006, s. 120; Dzik 2015, II, s. 181). Pewnym wyznacznikiem chronologicznym może być duży udział grobów z gwoździami, wynoszący dla trzech stanowisk łącznie ponad 40\%. Na Wysoczyźnie Drohiczyńskiej, a więc na obszarze o stosunkowo dużym udziale grobów zawierających gwoździe, zbliżone wartości stwierdzono jedynie $\mathrm{w}$ grobach $\mathrm{z}$ wyróżnionych tam podokresów B1 i B2 (ostatnia tercja lub ćwierć XI - 4 ćwierć XII w.). W kolejnych dziesięcioleciach udział grobów zawierających gwoździe spadł poniżej 10\% (Dzik 2015, II, s. 156). W tym samym regionie zwyczaje, których śladem są odkrywane w grobach węgle drzewne - stwierdzone przy pochówkach szkieletowych w dwóch grobach w Kotówku (Rostkach Małych) i dwóch w Rusi - powszechne były do XII w., a istniały jeszcze w 1 połowie kolejnego stulecia (Dzik 2015, II, s. 131).

Na podstawie zespołów zabytków odkrytych na cmentarzyskach w Kotówku (Rostkach Małych) i Rusi, założenie tych nekropoli można by umieszczać między połową XI a 1 ćwiercią XII w. Biorąc jednak pod uwagę konstrukcje grobów i datowanie obiektów o analogicznej budowie, znanych z o wiele lepiej rozpoznanych nekropoli nad górnym Orzycem i na Wysoczyźnie Drohiczyńskiej, do założenia cmentarzy mogło dojść najwcześniej w ostatniej tercji XI w., najpóźniej w 1 ćwierci kolejnego stulecia. Cezurą końcową funkcjonowania nekropoli w Kokoszkach, Kotówku (Rostkach Małych) i Rusi wydaje się okres między połową a końcem XII w. Należy jednak pamiętać, że zostały one rozpoznane szczątkowo, stąd nie można wykluczyć, że w rzeczywistości były użytkowane dłużej. Wydaje się to szczególnie prawdopodobne w odniesieniu do Rusi, ze względu na obecność grobu jamowego bez konstrukcji kamiennej (?), ale przede wszystkim ze względu na pierwotne rozmiary stanowiska.

\section{POZOSTAŁE CMENTARZYSKA WYSOCZYZNY KOLNEŃSKIEJ WYMIENIONE PRZEZ L. DE FLEURY'EGO}

W artykule z 1893 r., hrabia de Fleury napisał, iż w ciągu dwóch miesięcy poszukiwań na prawym brzegu Biebrzy, w promieniu 20 wiorst (nieco ponad $21 \mathrm{~km}$ ) odnalazł sześć cmentarzysk z grobami w kamiennych obstawach, w tym trzy wyżej opisane w: Kokoszkach, Rostkach Małych i Rusi oraz kolejne przy miejscowościach: Janczewko, Pieńki i Karwowo. Miał też uzyskać informacje o kilku 
innych, podobnych nekropolach. Wszystkie sześć nazw opublikował A. Spicyn, przy czym ostatnią z wymienionych w zniekształconej formie, jako „Kokwowo” (Spicyn 1925, s. 158). Owa pomyłka, ale również istnienie na Wysoczyźnie Kolneńskiej kilku miejscowości o zbliżonej nazwie, stały się przyczyną trwającej kilkadziesiąt lat dyskusji nad lokalizacją stanowiska (por. Kowalczyk-Heyman 2007b, s. 298-300). Obecnie najbardziej prawdopodobna jest, wskazana przez Elżbietę Kowalczyk-Heyman, lokalizacja na gruntach wsi Karwowo-Wszebory, gm. Jedwabne, pow. łomżyński. Przemawia za tym istnienie zapisanej już w XV w. nazwy terenowej "Żale”, obecność w okolicy kilku osad wczesnośredniowiecznych oraz położenie wsi w pobliżu innych stanowisk odkrytych przez de Fleury'ego (szerzej na ten temat: Kowalczyk-Heyman 2007b; por. też Ościłowski [2004-2005] 2006, s. 95, przypis 157).

W przypadku cmentarzyska w Janczewku nie ma wątpliwości, że chodzi o wieś w gminie Jedwabne, choć samo stanowisko nie zostało odnalezione. Być może znajdowało się w lesie zwanym „Żale”, niespełna kilometr na północny zachód od Janczewka (Ościłowski [2004-2005] 2006, przypis 157) ${ }^{23}$. Sugerowane w literaturze przedmiotu datowanie stanowisk w Karwowie i Janczewku na XII-XIII w. oparte zostało wyłącznie na hipotezie L. Rauhuta o czasie migracji osadników ze Starego Mazowsza na wschód i północny wschód (por. Rauhut 1971, s. 483, 484, 616, 617; Ościłowski [2004-2005] 2006, s. 95).

W piśmiennictwie archeologicznym panuje zgodność co do uznawania wymienionego przez L. de Fleury'ego cmentarzyska w Pieńkach za stanowisko w Pieńkach-Okopnych (dawniej Pieńki-Grodzisko; Kamiński 1961, s. 44-45; Kowalczyk-Heyman 2013, s. 191; por. też Rauhut 1971, s. 618 - tam dalsza literatura). Ze sprawozdania L. de Fleury'ego wynika, że rozkopał on tutaj co najmniej jeden grób, zawierający pochówek ciałopalny, analogiczny do tego z grobu nr 9 w Rusi. Cmentarzysko w Pieńkach-Okopnych było przedmiotem amatorskich rozkopywań w 1933 r., z których znany jest zbiór zabytków zawierający: kabłączki esowate, noże, krzesiwo, gwoździe oraz brązową misę (Antoniewicz 1951). L. Rauhut datował nekropolę na 2 poł. XII i XIII w. na podstawie wyposażenia, konstrukcji grobów i obecności trumien (Rauhut 1971, s. 618). Ustalenia te budzą wątpliwości. Obecnie wiadomo, że na cmentarzyskach $\mathrm{z}$ grobami w obudowach kamiennych pochówki w trumnach są znane już z najstarszych grobów (Dzik 2006, s. 100; tenże 2015, II, s. 151-156). O konstrukcjach grobów z Pieniek-Okopnych wiemy jedynie tyle, że składały się na nie m.in. obstawy z głazów widocznych na powierzchni. Odkrycie w obiekcie lub obiektach kości ludzkich (por. Antoniewicz 1951, s. 127) czyni bardziej prawdopodobną możliwość, iż były tam groby jamowe (w bezjamowych kości zwykle ulegają rozkładowi). Teoretycznie obecność jam może być przesłanką

${ }^{23}$ Obecnie las położony jest na gruntach sąsiedniej wsi, Janczewa. W trakcie prospekcji terenowej (M. Dzik, styczeń 2007 r.) nie znaleziono na powierzchni żadnych śladów grobowych konstrukcji kamiennych. Były właściciel lasu, Marian Remowlowski (ur. 1927) nie pamiętał, by znajdowały się w nim kopce lub skupiska kamieni. Nie znał też genezy nazwy „Żale”, przy czym w opinii jego ojca ktoś tam musiał być pochowany. Według niektórych rozmówców nazwę „Żale” nosił tylko południowo-zachodni odcinek lasu. Właśnie w tej części w 2007 r. widoczne były pozostałości wybranej żwirowni. 
chronologiczną, jednak w tym przypadku jest ona zbyt niepewna, by uznać ją za podstawę uściślania datowania. Pozostaje zatem zbiór zabytków, zapewne z kilku grobów. Odkrytą $\mathrm{w}$ jednym $\mathrm{z}$ nich misę brązową z ornamentem roślinnym zalicza się do typu V według Tadeusza Poklewskiego, datowanego w opinii autora klasyfikacji „na XII w., i to raczej na 1 połowę" (Poklewski 1961, s. 47). W nowszych opracowaniach zwraca się uwagę na możliwość pojawienia się tego typu mis już w XI w. (Müller 2011, s. 250-251 - tam dalsza dyskusja i literatura). Wszystkie pozostałe przedmioty mogły znaleźć się w grobach z XII w., a - jeśli wykluczyć kabłączek esowaty o średnicy około $5 \mathrm{~cm}$ - także z XI w. Biorąc pod uwagę datowanie zabytków oraz samych grobów w obudowach kamiennych na Mazowszu i obecnym Podlasiu, materiały znane z Pieniek-Okopnych można określić ramowo na 2 poł. XI i XII w.

\section{CMENTARZYSKA WYSOCZYZNY KOLNEŃSKIEJ NA TLE REGIONÓW SĄSIEDNICH}

Opisane wyżej prace wykopaliskowe L. de Fleury’ego, mimo niewielkiej skali i amatorskiego charakteru, stanowią obecnie jedną z głównych podstaw naszej wiedzy o wczesnośredniowiecznych cmentarzyskach Wysoczyzny Kolneńskiej. Wskazuje na to już choćby mapa nekropoli z XI-XII w., z których większość znana jest tylko lub głównie dzięki działaniom L. de Fleury’ego (ryc. 12). Zapewne słuszny jest pogląd E. Kowalczyk-Heyman, iż obecność grobów w obudowach kamiennych tylko we wschodniej strefie może być pozorna i spowodowana aktywnością L. de Fleury’ego właśnie w tej części regionu (Kowalczyk-Heyman 2013, s. 190).

Niezależnie od rzeczywistego rozprzestrzenienia cmentarzysk z grobami w obudowach kamiennych na tym obszarze, zwraca uwagę brak starszych obiektów, z których mogłaby wywodzić się ta forma grobów. Nie zmieniają tej konstatacji wiadomości o dwóch domniemanych kurhanach, o nieznanej chronologii (Kowalczyk-Heyman 2013, s. 192 - tam literatura). Z tego względu wydaje się, że na ten region należy rozciągnąć obserwację Tomasza Kordali przedstawioną w odniesieniu do północnego Mazowsza, o braku korzeni grobów w obudowach kamiennych w lokalnej obrzędowości pogrzebowej (Kordala 2006, s. 234-235). Idąc dalej, obecność grobów w obudowach kamiennych na Wysoczyźnie Kolneńskiej można interpretować jako ślad migracji bądź przesiedlenia ludności z innego regionu.

Przy próbach ustalenia, skąd mogła pochodzić ludność przesiedlona na Wysoczyznę Kolneńską konieczne jest zwrócenie uwagi przede wszystkim na podobieństwo zwyczajów pogrzebowych, jako najbardziej trwałych elementów kultury duchowej, w drugiej kolejności na zabytki ruchome.

Zważywszy na rodzaj konstrukcji grobowych, miejsca pochodzenia ewentualnych przesiedleńców należałoby szukać w pierwszej kolejności na północnym Mazowszu oraz w skupisku drohickim ${ }^{24}$. Pod względem formy, groby w obudowach

${ }^{24}$ Skupisko osadnicze nad wschodnim odcinkiem dolnego Bugu, ograniczone od północy Nurcem, od południa wododziałem lewych dopływów Bugu i Krzny. Wschodnia jego granica przebiega 


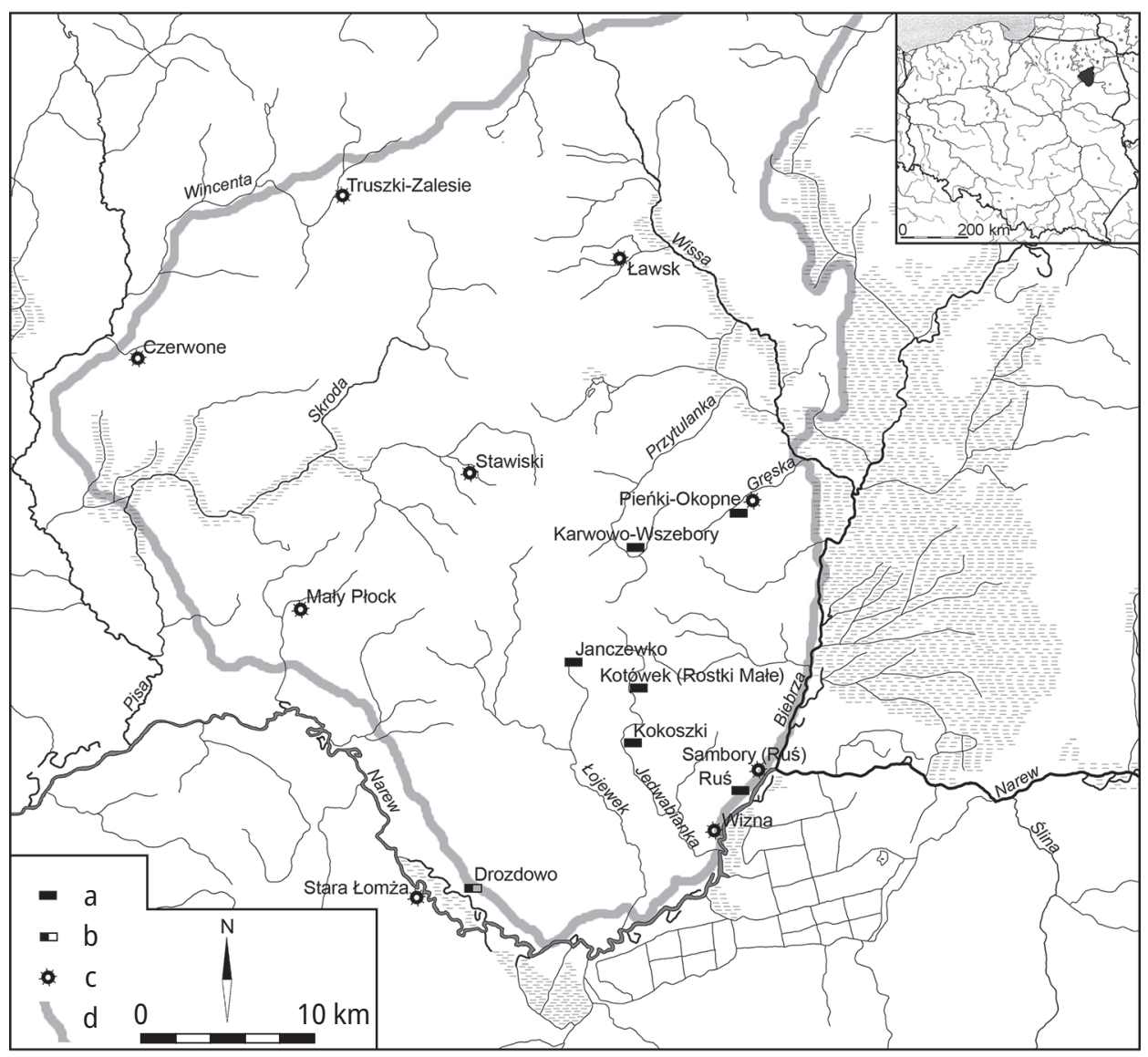

Ryc. 12. Położenie Wysoczyzny Kolneńskiej oraz lokalizacja cmentarzysk wczesnośredniowiecznych względem grodzisk na tym obszarze

a - cmentarzyska z grobami w obudowach kamiennych; b - cmentarzyska o nierozpoznanej konstrukcji grobów; c - grodziska; d - zasięg Wysoczyzny Kolneńskiej.

Wg Solon i in. 2018 (d). Na mapie uwzględniono obiekty datowane na XI i XII w., natomiast pominięto te o niepewnej chronologii (na ich temat: Kowalczyk-Heyman 2013, s. 152-195; Ościłowski 2013; Engel, Sobczak 2017); rys. M. Dzik

Fig. 12. The location of the Kolno Upland and of the early medieval cemeteries in relation to the stronghold sites from the region

$\mathrm{a}$ - cemeteries with stone-structure graves; $\mathrm{b}$ - cemeteries with unidentified grave structure; $\mathrm{c}$ - fort sites; $\mathrm{d}$ - the extent of the Kolno Upland.

After Solon et al. 2018 (d). Features taken into account are those dated to the $11^{\text {th }}$ and $12^{\text {th }}$ centuries but not those of uncertain chronology (on the latter: Kowalczyk-Heyman 2013, pp. 152-195; Ościłowski 2013; Engel, Sobczak 2017); drawing M. Dzik 
kamiennych z Wysoczyzny Kolneńskiej mają analogie nad górnym Orzycem, datowane według L. Rauhuta od XI/XII w., oraz w skupisku drohickim, gdzie datowane są od ostatniej tercji lub ćwierci XI w.

Między oboma regionami istnieje kilka podobieństw w zwyczajach pogrzebowych, które przejawiają się na przykład w sposobie zastosowania kamieni w konstrukcjach grobów, bądź w zwyczajach, których śladem jest częsta obecność węgli drzewnych w grobach. Wydaje się, że różnice są obserwowalne przede wszystkim w dwóch aspektach: w zbijaniu trumien (lub innych drewnianych konstrukcji) za pomocą gwoździ oraz w sposobie umieszczania naczyń w grobach.

Dla północnego Mazowsza charakterystyczne jest unikanie obecności gwoździ w grobach, skoro ich znaleziska są wyjątkowo rzadkie - odkryto je w zaledwie dwóch grobach w obudowach kamiennych (Kordala 2006, s. 191). Jest bardzo prawdopodobne, że nie jest to związane $\mathrm{z}$ niestosowaniem trumien, skoro tam, gdzie zaistniały warunki do zachowania się śladów po drewnie, stwierdzono częste ich występowanie, przy czym zbijane były drewnianymi kołkami (Dzik 2006, s. 61-63). $Z$ kolei na cmentarzyskach skupiska drohickiego odkryto ponad 100 grobów zawierających gwoździe i około 500 samych tych przedmiotów. Na tym obszarze używanie gwoździ w kontekście sepulkralnym, do XII w. włącznie, było zjawiskiem bardzo częstym (Dzik 2015, I, 239-244; II, 153-156, 184).

Na północnym Mazowszu powszechnym zwyczajem było składanie glinianych naczyń do grobu (Kordala 2006, s. 194-201). W skupisku drohickim, w żadnym obiekcie datowanym na XI lub XII w. nie odkryto naczynia umieszczonego w grobie w całości. Powszechnym zwyczajem było tu natomiast składanie do grobów ułamków naczyń rozbitych w innym miejscu (Dzik 2015, I, 261-264).

Pod wymienionymi względami, zwyczaje udokumentowane na cmentarzyskach z grobami w obudowach kamiennych na Wysoczyźnie Kolneńskiej odpowiadają znanym ze skupiska drohickiego. Podobieństw jest więcej. Przede wszystkim na cmentarzyskach omawianego regionu, podobnie jak w skupisku drohickim, nie odkryto grobów z głębokimi jamami wypełnionymi brukiem, jakie są znane ze Starego Mazowsza. Ponadto, w grobach nr 2 i 10 w Rusi głazy wyróżniające się prawdopodobnie dużymi rozmiarami ustawiono od strony nóg, co jest zwyczajem udokumentowanym na Wysoczyźnie Drohiczyńskiej (Dzik 2015, II, s. 41). Dalej, w Rusi odkryto grób potrójny, nr 6, który pod tym względem nie ma analogii na północnym Mazowszu. Podobny grób, tak pod względem formy, jak i liczby pochówków, odkryto natomiast w Aleksandrowie, w pow. siemiatyckim (Dzik 2015, II, ryc. 47). Jeśli pochówek nr 6c w Rusi został prawidłowo rozpoznany jako birytualny, to zwyczaj ten ma analogie w skupisku drohickim, nie ma ich natomiast na północnym Mazowszu.

Biorąc pod uwagę powyższe argumenty, uzasadnione wydaje się przyjęcie możliwości, iż ludność chowająca zmarłych na cmentarzyskach z grobami w obudowach

między Nurczykiem a Pulwą, na zachód zaś sięga ono po Cetynię i jej dopływy (por. Miśkiewiczowa 1981, s. 62-63; Dzik 2015, II, s. 173-174; na temat cmentarzysk między Bugiem a Krzną zob. Kalaga 2006). 
kamiennych na Wysoczyźnie Kolneńskiej pochodziła najprawdopodobniej z terenu skupiska drohickiego, ewentualnie z Równiny Bielskiej, skąd znana jest niewielka koncentracja cmentarzysk o cechach zbliżonych do tych z Wysoczyzny Drohiczyńskiej (Dzik 2015, II, s. 179-182, ryc. 57, 58) 25. Wśród zabytków stanowiących wyposażenie zmarłych jedynymi przedmiotami, które nie mają analogii w skupisku drohickim, są misy brązowe, znane z Rusi i Pieniek-Okopnych. Ich obecność, a także niektórych ozdób (paciorek guzowaty z Rusi, kabłączek skroniowy o średnicy $5 \mathrm{~cm}$ z Pieniek-Okopnych) stanowi dowód mocnych kontaktów kulturowych $\mathrm{z}$ Mazowszem. Jest to jednak tylko różnica surowca lub formy przedmiotów. Sam zwyczaj wyposażania zmarłych w naczynia, paciorki i ozdoby głowy jest potwierdzony w skupisku drohickim. Ludność migrująca, zwłaszcza w pierwszym pokoleniu, zachowywała stare zwyczaje pogrzebowe, lecz pewne ich elementy - zapewne głównie w warstwie elit społecznych - ulegały zmianie na skutek intensywnych kontaktów z Mazowszem.

\section{KONTEKST HISTORYCZNY}

W zdecydowanej większości opracowań historycznych przyjmowana jest hipoteza o ustaleniu trwałej granicy Polski i Rusi w północnej jej części, w latach 10411047, w związku ze wspólnymi walkami z Miecławem (np. Włodarski [1958-1959] 1959, s. 19-20, przypis 58; Bieniak 2010, s. 173; Pacuski 2019, s. 18). Stabilizacja ta miała trwać przynajmniej do 1145 r., kiedy w zamian za udzielenie pomocy militarnej Władysławowi II przeciw juniorom, wielki książę kijowski Wsiewołod Olegowicz miał otrzymać Wiznę; choć nie jest pewne, czy do tego doszło (PSRL 1908, szp. 318; por. Kamiński 1961, s. 22; Białuński 2003, s. 256-261; Kowalczyk-Heyman 2013, s. 231-234). Wyniki ostatnich analiz źródeł archeologicznych podważają jednak ów ustalony obraz (np. Dzik 2015, II, s. 187-194, 196-199; Olczak, Krasnodębski 2020, s. 482-495). Wydaje się, iż podział wpływów politycznych na północnym pograniczu nie był tak trwały, jak dotychczas przypuszczano, a linia tego podziału przez jakiś czas różniła się od rekonstruowanej na podstawie późniejszych źródeł (por. wnioski i mapy w: Gieysztor 2006, s. 120; Pacuski 2019, s. 19-30, ryc. 3.1; krytykę metodologii i ustaleń drugiej z tych prac przedstawił Przemysław Sianko [2019, s. 17-20]).

W źródłach pisanych z XI-XII w. niemal brak wiadomości o Wysoczyźnie Kolneńskiej. Spośród nazw miejscowych wymieniana jest w nich jedynie Wizna. Poza wzmianką w Latopisie hipackim, o domniemanym przejęciu jej przez księcia kijowskiego (por. wyżej), pojawia się też w tzw. falsyfikacie mogileńskim jako miejsce komory celnej około 1146 r. (a zapewne znacznie wcześniej, około 1065 r. lub na początku XII w.) i być może siedziba procuratore Troyano (Zbiór...1919, nr 22;

${ }^{25}$ Takiego kierunku migracji domyślał się już L. Rauhut, choć bez podania konkretnych podstaw. Stwierdził, że „w oparciu o formy pochówków i inwentarze grobowe dochodzimy do wniosku, że skupisko łomżyńsko-kolneńskie zostało zasiedlone z terenu Podlasia” (Rauhut 1971, s. 484, mapa II). 
o dokumencie m.in.: Arnold 1929; Płocha 1969). Źródła archeologiczne wskazują na zasiedlenie Wysoczyzny Kolneńskiej z kierunku mazowieckiego co najmniej od końca IX w., a trwałe włączenie tego obszaru pod władzę piastowską - od XI w. (Ościłowski [2004-2005] 2006, s. 98-99; tenże 2013, s. 105-106; Kowalczyk-Heyman 2013, s. 201-203, 326). W świetle przedstawionych wyżej argumentów zasadne jest postawienie hipotezy, że na owe z dawna zasiedlone ziemie w 2 poł. XI w. lub na początku XII w. przybyła ludność z południowego wschodu. Najprawdopodobniej miało to związek z sytuacją polityczną na pograniczu państwa piastowskiego. Z tego względu warto zwrócić uwagę na znane ze źródeł pisanych wydarzenia, które mogą mieć znaczenie dla zrozumienia i właściwej interpretacji sytuacji zaobserwowanej na podstawie źródeł archeologicznych.

Powieść minionych lat zawiera wiadomości o działaniach militarnych w sąsiedztwie Wysoczyzny Kolneńskiej w końcu lat trzydziestych XI w. Pod 1038 r. zapisana została wyprawa Jarosława Mądrego na Jaćwingów, a pod 1040 r. - na Litwę (PSRL 1926-1928, szp. 153; Powieść... 2005, s. 135-136). W latach 1041-1047 książę ruski, wraz z Kazimierzem Odnowicielem, prowadził działania wojenne przeciwko Miecławowi, które zakończyły się ponownym podporządkowaniem Mazowsza państwu piastowskiemu (PSRL 1926-1928, szp. 153, 155; PSRL 1908, szp. 141, 143; Powieść... 2005, s. 136-137; Gall 1952, I, 20, s. 45-46). Działania te niewątpliwie związane były także z rozdziałem zakresu wpływów i kształtowaniem strefy granicznej między Rurykowiczami a Piastami.

Lata 1069-1077, to kolejny okres, w którym mogło dojść do zmian przynależności politycznej ziem na pograniczu polsko-ruskim. Wiązało się to z wojną między Rurykowiczami i włączeniem się w nie Bolesława Śmiałego. W 1069 r. podjął on skuteczną wyprawę na Kijów, w celu przywrócenia tronu spokrewnionemu z nim Izjasławowi, obalonemu rok wcześniej przez Wsiesława (PSRL 1926-1928, szp. 173174; Powieść... 2005, s. 153-154). Nie wiadomo, czy interwencja ta pociągnęła za sobą jakieś cesje terytorialne. W tym kontekście w piśmiennictwie dyskutowana jest niemal wyłącznie kwestia ewentualnej zmiany przynależności tzw. grodów czerwieńskich (Delestowicz 2016, s. 117-118, 326-334 - tam dalsza literatura; na temat określenia „grody czerwieńskie” por. Jusupović 2017).

Izjasław został ponownie pozbawiony tronu kijowskiego w 1073 r., tym razem przez swych braci, Światosława i Wsiewołoda. Obalony książę powtórnie szukał pomocy u Bolesława, tym razem mniej skutecznie. Jest jednak bardzo prawdopodobne, że jakieś niepokoje miały miejsce na pograniczu polsko-ruskim, skoro przypuszczalnie około 1074 r. potrzebne było zawarcie pokoju między Bolesławem a Światosławem ${ }^{26}$. Wiadomo, że w efekcie porozumienia Bolesław przystał na panowanie Światosława w Kijowie oraz wydalił z kraju Izjasława, zaś nowy książę kijow-

26 Trafne wydaje się łączenie z tym czasem fragmentu Pouczenia Włodzimierza Monomacha, w którym jest mowa o posłaniu Włodzimierza zimą przez Światosława i Wsiewołoda do Brześcia, „na pogorzelisko", gdzie miał strzec grodów, a po Wielkiejnocy - do Włodzimierza i Sutiejska, gdzie miał zawrzeć pokój z Lachami (PSRL 1926-1928, szp. 247). Przyjmuję datowanie tych wydarzeń na jesień i zimę 1073/1074 r. (tak np. Linničenko 1884, s. 116-117; ostatnio Delestowicz 2016, s. 182-188 tam dalsza literatura), bądź na jesień i zimę 1074/1075 r. Niektórzy z historyków skłonni są łączyć je 
ski udzielił pomocy Śmiałemu w wojnie z Czechami (PSRL 1926-1928, szp. 199, 247). Ponownie nie wiemy, czy towarzyszyły tym wydarzeniom jakieś zmiany terytorialne.

Z końcem 1076 r. zmarł Światosław, a tron wielkoksiążęcy objął po nim brat Wsiewołod. Kilka miesięcy później Bolesław ponownie udzielił pomocy militarnej Izjasławowi, w wyniku czego ten powrócił na tron w Kijowie (PSRL 1926-1928, szp. 183, 199; PSRL 1908, szp. 173, 190; Powieść... 2005, s. 175-176). W literaturze przedmiotu brana jest pod uwagę ewentualna zmiana przynależności politycznej terenów pogranicznych, ale w tym kontekście dyskutowana jest tylko kwestia tzw. grodów czerwieńskich (Grudziński 2010, s. 46).

Wymienione wydarzenia nie są ostatnimi, z którymi mogły wiązać się zmiany przynależności regionów pogranicznych między Polską a Rusią w interesującym nas okresie. Kolejne miały miejsce w pierwszych latach XII w. Na początku czerwca 1102 r. zmarł Władysław Herman. Jego synowie, Zbigniew i Bolesław, szybko rozpoczęli starania o wzmocnienie swojej pozycji, w kraju i za granicą. Bolesław wszedł w sojusz z wielkim księciem kijowskim Światopełkiem Izjasławowiczem, którego przypieczętowaniem był ślub z jego córką Zbysławą, wysłaną do Polski w listopadzie 1102 r. (PSRL 1926-1928, szp. 276; por. Jasiński 1992,

z latami 1068-1070 (np. Ivakin 1901, s. 151-152; Solov'iev 1988, s. 672-673; Kučkin 1971, s. 29-32 tam dalsza literatura), ewentualnie datować je na zimę 1072/1073 r. (Kotyšev 2001, s. 8-10).

W literaturze przedmiotu powszechnie przyjmuje się, że Brześć został spalony przez Polaków, a wątpliwości w tej mierze przedstawił chyba tylko Tadeusz Wojciechowski (1970, s. 172-173, przypis 32). Sztandarowym przykładem tej interpretacji są polskie tłumaczenia, w tym autorstwa F. Sielickiego: „Tejże zimy posłali mnie bracia na pogorzelisko do Brześcia, który Lachowie spalili byli” (Powieść... 2005, s. 212) oraz R. Łużnego (Słowo... 1995, s. 85). Niestety, są to tylko przekłady wydania Powieści minionych lat w opracowaniu Dmitrija Lichaczowa, w którym autor, na podstawie domniemania (sic! - MD), wpisał „Lachów” do oryginalnej frazy „иде бяху [ляхове] пожгли” (PSRL 1926-1928, szp. 247; por. Povest'... 1950, s. 159, przypis 85), z której nie wynika kto wywołał pożar. Dosłownym przekładem na język polski, nie obarczonym tym przypuszczeniem, jest tylko pierwsze tłumaczenie (MPH 1864, s. 873). Przy interpretacji omawianej wzmianki warto zwrócić uwagę na kontekst tekstu Pouczenia: „се въ повъдаю . дъти моæ трудъ свои . шже с^ єсмь тружалъ . пути дъæ и ловъ . $\overrightarrow{\Gamma 1}$. льт . первоє к Ростову идохъ сквозъ ВАтичъ . посла мА жць . а самъ иде Курьску . и пакъ . $\overrightarrow{\mathrm{B}}$. $\epsilon$ к Смолиньску. со Ставкомь Скордятичемъ. тои пакъ1 и $\overline{\mathbf{w}} и д е$ к Берести ю. со Из А сла в о м . . мене посла Смолиньску. то и-Смолиньска идохъ Володимерю . тоєже зимъ . тои посласта Бе|рестию брата на головнб. и де 6 ^ ху по жгл л . . тои ту блюдъ городъ тихъ” (PSRL 1926-1928, szp. 247; rozstrzelonym drukiem zaznaczono fragmenty szczególnie istotne). W relacji peregrynacji Włodzimierza pojawia się wiadomość, iż do Smoleńska udał się ze Stawkiem Skordatyczem, który potem poszedł z Izjasławem do Brześcia. Niewątpliwie chodzi tutaj o czas wygnania Izjasława z Kijowa i jego pochód na zachód (por. Kučkin 1971, s. 31). Dwa wersy dalej źródło informuje o udaniu się Włodzimierza do Brześcia, który „spalili”. W tym kontekście tekst źródła zdaje się wskazywać na związek między spaleniem Brześcia a uprzednim pobytem w nim Izjasława i towarzyszących mu wojów, w tym Stawka. Nie można zatem wykluczyć, że do spalenia grodu doszło wskutek nieznanych nam działań Izjasława. Niezależnie od tego, kto spowodował pożar Brześcia, wiadomość ta wskazuje na niespokojną sytuację w tej części Nadbuża. Gród ten także w latach 1097 i 1101 stawał się miejscem konfrontacji książąt ruskich, co także świadczy o politycznym napięciu w regionie (PSRL 1926-1928, szp. 271, 275; PSRL 1908, szp. 246, 250). 
s. 188-190). Źródła milczą jednak o ewentualnej wzajemnej pomocy militarnej w pierwszych latach zawarcia sojuszu. Jej śladem jest dopiero pojawienie się posiłków ruskich po stronie Bolesława, w drugiej fazie wojny ze Zbigniewem, w 1106 r. (Gall 1952, II, 38; por. Włodarski 1966, s. 43-44). Przed ich przybyciem, najprawdopodobniej wkrótce po rozpoczęciu walk, Zbigniew udał się jednakże na dwór Światopełka (Gall 1952, II, 37; PSRL 1926-1928, szp. 281; Powieść... 2005, s. 250). Niewątpliwie uzyskał jego wsparcie dyplomatyczne, skoro wkrótce, dzięki pośrednictwu syna Światopełka Jarosława, księcia włodzimierskiego, udało mu się zakończyć przegraną wojnę i utrzymać przynajmniej Mazowsze (Gall 1952, II, 38; Maleczyński 2010, s. 72-73). Zdarzenia te są zastanawiające z co najmniej dwóch powodów. Pierwszym jest kierunek poszukiwania pomocy przez Zbigniewa, wobec oczywistego, potwierdzonego powinowactwem sojuszu Światosława z Bolesławem. Drugim jest sprzyjanie Zbigniewowi przez Światopełka, mimo udzielenia przez tego ostatniego pomocy militarnej Bolesławowi (niezależnie od tego, czy wojska wysłał wielki książę kijowski, czy jego syn Jarosław). Zasadne wydaje się przypuszczenie, że Zbigniew także wszedł wcześniej w układ ze Światosławem i jego synem, a otwarte jest pytanie, na jakich warunkach ${ }^{27}$. Dla księcia kijowskiego korzyścią z sojuszu z Bolesławem było zapewne głównie szachowanie z dwóch stron wrogich mu Rościsławiczów (Włodarski 1966, s. 41-42). Brak natomiast źródeł pozwalających wyjaśnić, jakie korzyści chciał on odnieść z przyjaznej neutralności wobec Zbigniewa, a nawet dyplomatycznego tegoż wspierania, potwierdzonego w 1106 r., ale trwającego być może już od $1102 \mathrm{r}^{28}$ Niewykluczone więc, że tą korzyścią była cesja terytorialna na ziemiach przyległych do księstwa włodzimierskiego.

Biorąc pod uwagę powyższą hipotezę warto powrócić do informacji źródłowych dotyczących lat 1097-1100. W tym okresie doszło do spotkania Światopełka i Władysława Hermana w Brześciu (PSRL 1926-1928, szp. 269; Powieść... 2005, s. 239). Wybór tego grodu na ów zjazd, sposób wzmiankowania Brześcia w tym okresie $^{29}$, wreszcie wiadomość, iż Lachowie na czas negocjacji stanęli nad Bugiem, sugerują, iż był to ruski gród graniczny, a po drugiej stronie rzeki znajdowały się wówczas ziemie lackie (por. Maleczyński 2010, przypis 79). Wydaje się to wzmacniać przypuszczenie, iż do zmiany przynależności państwowej ziemi drohickiej na rzecz książąt ruskich mogło dojść po tych wydarzeniach.

${ }^{27}$ Hipoteza o małżeństwie Zbigniewa z córką Światopełka nie ma żadnych podstaw źródłowych (por. Maleczyński 2010, s. 59, przypis 20). Ich brak jest szczególnie znamienny w kontekście odnotowania mariażu Bolesława zarówno w źródle polskim, jak i ruskim.

${ }^{28}$ W rocznikach ruskich brak jest jakichkolwiek wiadomości o włączaniu się militarnym książąt ruskich w konflikt wewnętrzny w Polsce, bądź innym współdziałaniu Bolesława ze Światopełkiem. Udział posiłków ruskich wzmiankowany jest tylko przez Galla Anonima, dwukrotnie (1106 i 1107 r.; Gall 1952, II, 38, 41). Pewne znaczenie w analizie stanowiska Światopełka względem polskich książąt może mieć również okoliczność, że w obu przypadkach Rusini stawali raczej w końcowej fazie walk, tylko przeciw stronnikom Zbigniewa pozostałym po ucieczce księcia, nie zaś przeciw niemu samemu.

${ }_{29} \mathrm{~Np}$. „Światopełk [...] poszedł do Brześcia ku Lachom”; „Jarosław uciekł do Lachów i przyszedł do Brześcia” (Powieść... 2005, s. 239, 241; PSRL 1926-1928, szp. 269, 271). 


\section{PODSUMOWANIE}

Opisane wyżej wypadki i niestabilność polityczna w latach 1031-1047, 10691077 oraz pod koniec XI i na początku XII w., mogły wywołać migracje w północnej części pogranicza polsko-ruskiego. Teoretycznie ich powodem mogło być dążenie danych grup ludności do zapewnienia sobie bezpieczeństwa, na przykład przez pozostanie pod podległością danemu władcy przy zmieniających się granicach. Migracja mogła być również - i to wydaje się bardziej prawdopodobne - wynikiem przemieszczenia przez władcę osadników z jednego regionu do drugiego, także w związku ze zmianami politycznymi. Przesiedlenia jeńców w tym kontekście wydają się mało prawdopodobne, przede wszystkim ze względu na bliskość regionu wyjściowego i docelowego (i w związku z tym ryzyko ucieczki), a także biorąc pod uwagę wysoki status materialny niektórych osób pochowanych w najstarszych z odsłoniętych grobów.

Kilka lat temu zaproponowano hipotezę wyjaśniającą obecność cmentarzysk $\mathrm{z}$ grobami w obudowach kamiennych w skupisku drohickim oraz na Równinie Bielskiej chrystianizacją z kierunku zachodniego, prowadzoną najprawdopodobniej w czasach rządów Bolesława Śmiałego i Władysława Hermana (Dzik 2015, II, s. 183-194; tenże 2019, s. 107-112). Przyjmując ją, pojawienie się takich nekropoli na Wysoczyźnie Kolneńskiej może być wiązane z okresem od panowania wymienionych władców do czasu współrządów Zbigniewa i Bolesława Krzywoustego.

Niezależnie od tego, czy owa migracja ludności była bezpośrednio związana ze zmianą przynależności politycznej skupiska drohickiego, czy też od niej niezależna, to sprzyjała ona wzmocnieniu potencjału obronnego północno-wschodnich rubieży Mazowsza. A było to działanie wskazane z punktu widzenia książąt piastowskich, ze względu na sąsiedztwo Prusów, ale i Rusinów, umacniających się na nieodległej Grodzieńszczyźnie (por. Kowalczyk-Heyman 2013, s. 99, 206; Nazarenko [2007] 2009, s. 139).

Warto na koniec zwrócić uwagę na chronologię grodzisk we wschodniej części Wysoczyzny Kolneńskiej, a więc w tej, z której znane są cmentarzyska z grobami w obudowach kamiennych. Najistotniejszą rolę pełnił tu prawdopodobnie gród w Wiźnie, którego pozostałości we wstępnych sprawozdaniach o wynikach badań wykopaliskowych datowano od XII w. (Janiszowski 1969; 1970; 1971), choć jest prawdopodobne, że powstał już w drugiej połowie XI w. (Kowalczyk-Heyman 2013, s. 234). Dwie nekropole z grobami w obudowach kamiennych odkryto bardzo blisko grodzisk w Pieńkach-Okopnych oraz w Samborach (Rusi). Oba założenia obronne zostały rozpoznane, niestety, w niewielkim stopniu. Na podstawie dotychczasowych badań początek ich funkcjonowania datowany jest na XII w. (Kaczmarek 1985; Pela, Skrok 1987, s. 123; por. Kowalczyk-Heyman 2013, s. 160-162 - tam uwagi odnośnie do ustaleń i dalsza literatura).

Zważywszy na chronologię cmentarzysk i znajdujących się w ich pobliżu grodzisk można postawić hipotezę, iż wzniesienie grodów osłaniających północno-wschodnie Mazowsze od strony Prus i Rusi - przynajmniej w Samborach (Rusi) i Pieńkach-Okopnych - mogło być powiązane w czasie z pojawieniem się tutaj lud- 
ności chowającej zmarłych w grobach z obudowami kamiennymi. Prawdopodobnie nowi osadnicy zostali sprowadzeni na tereny zajęte już od dłuższego czasu. Sugeruje to zagęszczenie stanowisk wczesnośredniowiecznych, choć brak dokładniejszych badań uniemożliwia ustalenie początków funkcjonowania osad w rejonie wspomnianych grodów (Kowalczyk-Heyman 2013, s. 204-206, ryc. 41; por. też Olczak, Krasnodębski 2020, s. 479, przypis 14). Propozycja powiązania budowy grodów z czasem pojawienia się ludności chowającej zmarłych w grobach w obudowach kamiennych jest obarczona ryzykiem błędu wynikającym $\mathrm{z}$ ramowego datowania źródeł archeologicznych, zwłaszcza z tak słabo rozpoznanych stanowisk. Być może jednak, po uzupełnieniu stanu wiedzy o ich chronologii, zwłaszcza grodzisk w Pieńkach-Okopnych i Samborach (Rusi), hipoteza ta będzie mogła zostać zweryfikowana.

W podsumowaniu sprawozdania L. de Fleury napisał: „Trzeba się spieszyć [z badaniem cmentarzysk - MD], ponieważ z każdym dniem istnieje większe zapotrzebowanie na kamienie na budowę. Uprzedzenia i pewien religijny strach, które chroniły te starożytne cmentarzyska, stopniowo słabną, i za kilka lat próżno będziemy szukać tych zabytków tajemniczej przeszłości." (RONA IIMK, zb. 1, 1-1890/28, k. 11r). Niestety, francuski i jednocześnie miejscowy miłośnik starożytności miał pełną słuszność. Wszystkie opisane przez niego nekropole zostały zniszczone, zanim pojawili się na nich profesjonalni archeolodzy. Mimo zatem niewielkiej liczby rozpoznanych grobów i niepełnej dokumentacji, informacje podane przez L. de Fleury’ego pozostaną prawdopodobnie najważniejszym źródłem wiedzy o tych cmentarzyskach.

\section{WYKAZ CYTOWANEJ LITERATURY}

\section{ŹRÓDŁA PISANE I KARTOGRAFICZNE}

Gall 1952

Мара 1980

M P H 1864

Osteuropa 1915

Povest'... 1950

Powieść... 2005

P SRL 1908
Galli Anonymi Cronicae et gesta ducum sive principium polonorum, wyd. i oprac. K. Maleczyński, Monumenta Poloniae Historica. Nova series, II, Cracoviae.

Mapa topograficzna, ark. 244.223, 244.224, 244.241, 244.242, skala 1:10 000, wyd. Główny Urząd Geodezji i Kartografii, Warszawa.

Włodzimierza Monomacha nauka i list do Olega, [w:] Monumenta Poloniae Historica, wyd. A. Bielowski, 1, Lwów, s. 863-884.

Osteuropa, arkusz. Gruppe Grodno XIX 12-B, skala 1:25 000, wyd. Kartographischen Abteilung des Stellvertretenden Generalstabes der Armee, Berlin.

Povest' vremennyh let, 1, opracowanie D.S. Lihačev, tłumaczenie D.S. Lihačev, B.A. Romanov, Moskva-Leningrad.

Powieść minionych lat. Najstarsza kronika kijowska, tłumaczenie i opracowanie F. Sielicki, Wrocław.

Ipat'evskaâ letopis', [w:] Polnoe sobranie ruskih letopisej, 2, wyd. 2, S.-Peterburg. 
P S R L 1926-1928

Stowo... 1995

T K K P [ 1839] 1843

T M K 1808

Zbiór... 1919
Povest' vremennyh let, [w:] Polnoe sobranie ruskich letopisej, 1: Lavrent'evskaâ letopis', 1, wyd. 2, Leningrad.

Słowo o Bogu i człowieku. Myśl religijna Słowian Wschodnich doby staroruskiej, tłumaczenie i opracowanie R. Łużny, Kraków.

Topograficzna Karta Królestwa Polskiego, arkusz 32 Łomża, skala 1:126 000, oprac. Kwatermistrzostwo Generalne Wojska Polskiego, Korpus topografov Rossijskoj imperatorskoj armii.

Topographisch-militärische Karte vom vormaligen Neu-Ostpreussen oder dem jetziger Nördlichen Theil des Herzogthums Warschau, nebst dem russischen District..., sekcja 9, skala około 150 000, wyd. J.Ch. Textor, Berlin.

Zbiór ogólny przywilejów i spominków mazowieckich, wyd. J.K. Kochanowski, Warszawa.

\section{OPRACOWANIA}

A n t o n i e wi c z J. 1951, Zabytki wczesnośredniowieczne odkryte we wsi Pieńki-Grodzisko, pow. Łomża, „Sprawozdania P.M.A., 4/1-2, s. 125-143.

A r nold S. 1929, Początki biskupstwa płockiego w świetle falsyfikatów mogilneńskich, „Rocznik Towarzystwa Naukowego Płockiego", 1, 3-24.

Ave n a ri u s N.P. 1890, Drogičin" Nadbužsskij i ego drevnosti, [w:] Drevnosti sěvero-zapadnago krâ̂, Materialy po archeologii Rossii, 4, Sanktpeterburg', s. 2-42.

Ave n a ri u s N. P. 1897, Kratkiâ izvěstiâ o Běl'skom" u. Grodnenskoj gub., [w:] Trudy vos'mago arheologičeskago sězda v" Moskvě - 1890, red. P.S. Uvarova, III, Moskva, s. 324-325.

B a n a i e w i c z P. 2006, Zabytki wczesnośredniowieczne w zbiorach Muzeum Diecezjalnego w Płocku (kolekcja Franciszka Tarczyńskiego), maszynopis pracy magisterskiej przechowywany w archiwum Wydziału Archeologii Uniwersytetu Warszawskiego, Warszawa.

B el's k ij S. V. 2012, Mogil’nik Kûlâlahti Kalmistomâki v severo-zapadnom Priladože (Arheologičeskie issledovaniâ 2006-2009 godov), Sankt-Peterburg.

B i ał u ń s k i G. 2003, Wizna na pograniczu mazowiecko-pruskim w czasach Bolesława Kędzierzawego, [w:] Pogranicze polsko-pruskie i krzyżackie. Materiały z konferencji naukowej Górzno, 1-2 czerwca 2002 r., K. Grążawski red., Włocławek-Brodnica, s. 255-276.

B i e n i k J. 2010, Państwo Miecława. Studium analityczne, wyd. 2, Warszawa.

Bi eńkowska A.M. 2010, Wczesnośredniowieczne cmentarzysko typu mazowieckiego w Skiwach Małych, pow. Siemiatycze, „Podlaskie Zeszyty Archeologiczne”, 6, s. 129-140.

Bieńkowska A., D zik M., P i s e cka K. 2013, Średniowieczne cmentarzysko w Czarnej Wielkiej, stan. 1, woj. podlaskie (badania 1951-1978), I, Białystok.

B i eń kowska K. 2005, Cmentarzysko wczesnośredniowieczne w Surażu, woj. podlaskie, „Podlaskie Zeszyty Archeologiczne”, 1, s. 121-166.

B l o m b e r g o w a M. M. 1986, Učastie polâkov v russkih arheologičeskih s'ezdah (1869-1914), „Fasciculi Archaeologiae Historicae”, 1, s. 19-26.

B lo m be r g ow a M.M. 1988, Polscy członkowie rosyjskich towarzystw archeologicznych 1839-1914, „Acta Archeologica Lodziensia”, 35, s. 7-143.

B lo m b e r g o w a M. M. 1989, Juliana Talko-Hryncewicza i Gotfryda Ossowskiego kontakty $z$ Cesarska Komisija Archeologiczna w Petersburgu, „Kwartalnik Historii Nauki i Techniki”, $35 / 2$, s. 271-282. 
B lo m b e r g ow a M. M. 1993, Badania archeologiczne Polaków na terytorium Imperium Rosyjskiego w XIX i początku XX wieku, Łódź.

Bła s z c z y k D., S t a n a s z e k Ł. M. 2016, Grób 609 z Czerska, stan. 1, w świetle nowych badań, [w:] Czersk. Wzgórze Zamkowe. Badania 1974-1983, P. Urbańczyk, M. Trzeciecki red., Warszawa, s. 323-332.

Bojarski J., Chudziak W., Drozd A., Koperkiewicz A., Kozłowski T., S t a w ska V. 2010, Katalog źródeł, [w:] Wczesnośredniowieczne cmentarzysko szkieletowe w Kałdusie (stanowisko 4), W. Chudziak red., Toruń, s. 189-603.

B r o n i cka - R a u h t J. 1998, Cmentarzysko wczesnośredniowieczne w Czersku, Warszawa.

B ron i cka-R a u h t J., R a u u t L. 1977, Wczesnośredniowieczne cmentarzysko szkieletowe w Starogrodzie, woj. Siedlce, „Wiadomości Archeologiczne”, 42/1, s. 58-86.

B u k o A. 2009, Zespół wieżowy w Stołpiu: badania 2003-2005, Warszawa.

B u k o A. re d. 2019, Średniowieczny zespół rezydencjonalny na Górze Katedralnej w Chełmie, Warszawa.

B u r e k K. 1977, Starożytnicy i archeolodzy. Z dziejów badań archeologicznych na Białostocczyźnie, Olsztyn.

Chilmon K. 1974, Badania wykopaliskowe wczesnośredniowiecznych cmentarzysk kurhanowych w Czarnej Wielkiej i Czarnej Cerkiewnej, pow. Siemiatycze, „Sprawozdania Archeologiczne", 26, s. 301-316.

Ci és li ń ski A. 2014, Kopce kultury wielbarskiej z Mazowsza i Podlasia a tzw. typ rostołcki - próba nowego spojrzenia na związki cmentarzysk kurhanowych z północnej i wschodniej Polski, „Wiadomości Archeologiczne”, 65, s. 46-91.

C z e ch - Błoń ska R. 2016, Paciorki z kamieni pótszlachetnych, [w:] Bodzia. Elitarny cmentarz z początków państwa polskiego, A. Buko red., Warszawa, s. 107-214.

Delestowicz N. 2016, Bolesław II Szczodry. Tragiczne losy wielkiego wojownika, 1040/1042-2/3 IV 1081 albo 1082, Kraków.

Dłu go p olska L. 1973, Zdobione misy romańskie z Pokrzywnicy Wielkiej, pow. Nidzica, „Wiadomości Archeologiczne”, 38/2, s. 325-328.

Długopolska L. 1991, Wstępne sprawozdanie z badań prowadzonych $w$ Narojkach gm. Drohiczyn, woj. białostockie na wczesnośredniowiecznym cmentarzysku Mogiłki, „Rocznik Białostocki”, 17, s. 388-393.

D uczko W. 2016, Status i magia. Ozdoby elit z Bodzi, [w:] Bodzia. Elitarny cmentarz z początków państwa polskiego, A. Buko red., Warszawa, s. 131-151.

D u lin i c z M. 2008, Cmentarzysko wczesnośredniowieczne w Tańsku-Kęsosze w świetle badań wykopaliskowych z lat 1961, 1969, 1971, maszynopis pracy magisterskiej przechowywany w archiwum Wydziału Archeologii Uniwersytetu Warszawskiego, Warszawa.

Dziedzictwo 2006, Dziedzictwo archeologiczne Podlasia i grodzieńszczyzny, Białystok.

D z i k M. 2006, Wczesnośredniowieczne cmentarzysko szkieletowe w Żukowie, pow. Płońsk, „Światowit”, Supplement Series P: Prehistory and Middle Ages, 13, Warszawa.

D z i k M. 2014a, Metalowe ozdoby i części stroju, [w:] Średniowieczne cmentarzysko w Czarnej Wielkiej, stan. I, woj. podlaskie (badania 1951-1978), II, H. Karwowska red., Białystok, s. 161-194.

D z i k M. 2014b, Układ pochówków, [w:] Średniowieczne cmentarzysko w Czarnej Wielkiej, stan. 1, woj. podlaskie (badania 1951-1978), II, H. Karwowska red., Białystok, s. 27-39.

D z i k M. 2015, Przemiany zwyczajów pogrzebowych w międzyrzeczu Bugu i górnej Narwi (XI-XV w.), I-II, Rzeszów.

D z i k M. [2012] 2016, Cmentarzysko w Rogawce w pow. siemiatyckim w świetle badań Siergieja Dubinskiego w 1910 roku, „Światowit”, 10 (60)/B, s. 205-236. 
D zik M. 2017, Zabytki z wczesnośredniowiecznych cmentarzysk z grobami w obudowach kamiennych pochodzące z badań Nikolaja P. Awenariusa, „Materiały i Sprawozdania Rzeszowskiego Ośrodka Archeologicznego", 38, s. 185-196.

D z i k M. 2019, Cmentarzyska i migracje. Osadnictwo w pótnocnej części pogranicza polsko-ruskiego w XI-XII wieku w świetle materiałów ze stanowisk sepulkralnych, [w:] Pogranicza w polskich badaniach mediewistycznych, A. Janeczek, M. Parczewski, M. Dzik red., Materiały V Kongresu Mediewistów Polskich, 3, Rzeszów, s. 79-121.

E nge l M., S o b c z a k C. 2017, Nieznane grodziska w okolicach Łomży. Nowe źródła do badań nad krajobrazem archeologicznym pótnocno-wschodniego Mazowsza, [w:] Fines testis temporum. Studia ofiarowane Profesor Elżbiecie Kowalczyk-Heyman w pięćdziesięciolecie pracy naukowej, M. Dzik, G. Śnieżko red., Rzeszów, s. 249-264.

É t a t... 1892, État de la Société Archéologique et Historique de la Charente. Au 31 Decembre 1890, „Bulletin et mémoires de la Société archéologique et historique de la Charentes”, 1890-1891, s. I-XXII.

Fl e u r y L. d e 1893, Les cimetières à compartiments de l'ancien pays de Jadzwingues, [w:] Congrès international d'archéologie et d'anthropologie préhistoriques. II-ème Session, à Moscou, du 1/13 - 8/20 août 1892, II, J. Dumouchel, D. Anoutchine red., Moscou, s. 331-336.

Fle u r y L. d e 1894, Les Tumuli du Caucase fouillés par M. le professeur Samokwassoff et leur rapport avec ceux du département de la Charente, Angouléme.

Frühmit telalterliche... 2013, Frühmittelalterliche Münzfunde aus Polen. Inventar IV. Kleinpolen. Schlesien, M. Bogucki, P. Ilisch, S. Suchodolski red., Warszawa.

G i e y s z t o r A. 2006, Trzy stulecia najdawniejszego Mazowsza (połowa X-połowa XIII w.), [w:] Dzieje Mazowsza, 1, H. Samsonowicz red., Pułtusk, s. 109-160.

Gr u d z i ń s k i T. 2010, Bolesław Śmiały-Szczodry i biskup Stanisław. Dzieje konfliktu, Kraków.

Iv a k i n I. M . 1901, Knâz' Vladimir" Monomah" i ego Poučenie, 1: Poučenie detâm”, pis'mo k" Olegu i otryvki, Moskva.

J a n i s z o w s i K. 1969, Wizna, pow. Łomża, Informator Archeologiczny. Badania 1968 r., Warszawa, s. 316-318.

J a n i s o w s ki K. 1970, Wizna, pow. Łomża, Informator Archeologiczny. Badania 1969 r., Warszawa, s. 340-341.

J a n i s z o w s ki K. 1971, Wizna, pow. Łomża, Informator Archeologiczny. Badania 1970 r., Warszawa, s. 219.

Ja now ski A. 2003, Misy brązowe atrybutem wyposażenia? Groby z misami brąowymi na terenie ziem polskich we wczesnym średniowieczu, [w:] Kobieta - Śmierć - Mężczyzna, W. Dzieduszycki, J. Wrzesiński red., Funeralia Lednickie, 5, Poznań, 331-347.

J a n o w k i A. 2019, Naczynia, [w:] Ciepłe. Elitarna nekropola wczesnośredniowieczna na Pomorzu Wschodnim, S. Wadyl red., Gdańsk, s. 269-278.

Ja nowski A., Kurasiński T. 2008, (Nie)militarne naczynia. Fakty i mity, „Acta Archaeologica Lodziensia", 54, s. 61-88.

J a s i ń s k i K. 1992, Rodowód pierwszych Piastów, Poznań.

J a s k a n is D. 1962, Materiały z badań wczesnośredniowiecznego cmentarzyska w miejscowości Podroś koło Wołkowyska w BSRR, „Rocznik Białostocki”, 3, s. 337-363.

J a s k a n is D. 2004, O lokalnych właściwościach zausznic o kabłąku oplatanym filigranem oraz ornamentowanych kabłączków esowatych, [w:] Hereditatem cognoscere. Studia i szkice dedykowane Profesor Marii Miśkiewicz, Z. Kobyliński red., Warszawa, s. 218-224. 
J a s k a n is D. 2008, Święck. Wczesnośredniowieczny zespót osadniczy na pótnocno-wschodnim Mazowszu, Warszawa.

J a s k a $\mathrm{n}$ is J. 1956a, Kotowo-Plac, pow. Łomża, „Dawna Kultura”, 1956/2, s. 144-145.

J a s k a $\mathrm{n}$ i s J. 1956b, Szklane paciorki z miejscowości Kotowo-Plac, pow. Łomża, „Wiadomości Archeologiczne", 23/2, s. 212-213.

Joń c zy k L. 2013, Zapinki podkowiaste w kontekście europejskich analogii, [w:] Sutiejsk. Gród pogranicza polsko-ruskiego $z$ X-XIII wieku. Studium interdyscyplinarne, J. Kalaga red., Warszawa-Pękowice, s. 41-59.

Jusupović A. 2017, “червенъ и ины грады” ог "гроды червеньскыя"? History of the domain of Cherven' in the written record (10 $10^{\text {th }} 13^{\text {th }}$ centuries), [w:] From Cherven' Towns to Curzon Line. The lands on the Middle Bug during the Middle Ages and the historiographic perspective on the formation of Poland's eastern border, $18^{\text {th }}-21^{\text {st }}$ centuries, M. Wołoszyn red., U Źródeł Europy Środkowo-Wschodniej, 3, Kraków-Leipzig-Rzeszów-Warszawa, s. 31-105.

K a c z m a re k L. 1985, Ruś, gm. Wizna, Informator Archeologiczny. Badania rok 1984, Warszawa, s. 142-143.

Ka la g a J. 2006, Ciałopalny obrządek pogrzebowy w międzyrzeczu Liwca, Bugu i Krzny we wczesnym średniowieczu, Warszawa.

Ka miński A. 1956, Materiały do bibliografii archeologicznej Jaćwieży od I do XIII w., Materiały Starożytne, I, Warszawa, s. 193-273.

Ka m ińs k i A . 1961, Wizna na tle pogranicza polsko-rusko-jaćwieskiego, „Rocznik Białostocki”, 1, s. 9-61.

Ka s ze w s y E. i Z. 1971, Wczesnośredniowieczne cmentarzysko w Brześciu Kujawskim, pow. Włocławek, Materiały Starożytne i Wczesnośredniowieczne, I, Warszawa, s. 365-434.

Ka t a log 1893, Katalog" predmetov", dostavlennyh" na arheologičeskuû vystavku pri IX arheologičeskom' s'ezdě v"Vil’ně v" 1893 godu, Vil'na.

Katalog 1898, Katalog" vremennoj hudožestvennoj vystavki v" gor. Lomžě v" Sentâbre 1898 goda / Katalog czasowej wystawy sztuk pięknych w Łomży we Wrześniu 1898 roku, Lomža.

Ki r p ičn i kov A.N. 1966, Drevnerusskoe oružie, 1, Meči i sabli IX-XIII vv., Archeologiâ SSSR. Svod arheologičeskih istočnikov, E1-36, B.A. Rybakov red., Moskva-Leningrad.

Kó č k a - K r e n z H. 1971, Esowate kabłaczki skroniowe z terenów Polski pótnocno-zachodniej, „Fontes Archaeologici Posnanienses”, 22, s. 97-143.

Kó č k a - K r e n z H. 1993, Biżuteria pótnocno-zachodnio-słowiańska we wczesnym średniowieczu, Poznań.

Ko p e r n i cki I. 1883, Czaszki i kości z trzech starożytnych cmentarzysk zdobione kółkami kąbłączkowémi (Hackenringe), „Zbiór Wiadomości do Antropologii Krajowéj”, 7, s. 3-40.

Ko rdala T. 1992, Cmentarzysko $z$ XI-XII wieku w Płocku-Podolszycach, „Rocznik Muzeum Mazowieckiego w Płocku", 15, s. 3-96.

Kordala T. 2003, Podstawy chronologii wczesnośredniowiecznych cmentarzysk szkieletowych na Północnym Mazowszu, [w:] Słowianie i ich sąsiedzi we wczesnym średniowieczu, M. Dulinicz red., Lublin-Warszawa, 303-310.

Ko r d a la T. 2006, Wczesnośredniowieczne cmentarzyska szkieletowe na pótnocnym Mazow$s z u$, Łódź.

Kości ele cki P. 2000, Topografia wyposażenia grobów męskich na staromazowieckich cmentarzyskach z grobami w obudowach kamiennych z XI-XIII wieku, „Studia i Materiały Archeologiczne", 10, s. 55-88. 
Kotańska A. 1997, Ilustratorzy i drzeworytnicy czasopism ilustrowanych drugiej połowy XIX w.: na marginesie katalogu drzeworytów o tematyce warszawskiej, „Almanach Muzealny", 1, s. 85-116.

K o t y š e v D. M . 2001, K voprosu o datirovke odnogo fragmenta „Poučeniâ” Vladimira Monomaha, „Vestnik Čelâbinskogo gosudarstvennogo universiteta”, seriâ 1, Istoriâ, 1, s. 6-12.

Kowalczyk-Heyman E. 2007a, Cmentarzysko w Jedwabnem, gm. loco, czyli o tym, jak nie należy korzystać ze źródeł i opracowań z drugiej ręki, „Rocznik Mazowiecki”, 19, s. 295-297.

Kow a lc zyk-He y m a n E. 2007b, Cmentarzysko w Karwowie: przyczynek do wspótpracy archeologiczno-toponomastyczno-historycznej, „Rocznik Mazowiecki”, 19, s. 298-304.

Kow alczyk-Heyman E. 2013, Dzieje granicy mazowiecko-krzyżackiej (między Pisa a Biebrza), Warszawa.

K u č k i n V.A. 1971, „Poučenie” Vladimira Monomaha i russko-pol'sko-nemeckie otnošeniâ 60-70-h gg. XI veka, „Sovetskoe slavânovedenie”, 2, s. 21-34.

Ku fel- D z i e r z g o w s k a A. 1975, Wczesnośredniowieczne cmentarzyska szkieletowe w Polsce środkowej, „Prace i Materiały Muzeum Archeologicznego i Etnograficznego w Łodzi. Seria Archeologiczna", 22, s. 374-390.

K u r a s i ń $\mathrm{s}$ i T. 2016, Stave vessels as part of post mortem furnishings in Early Medieval Polanda problem outline and research perspectives, „Fasciculi Archaeologiae Historicae”, 29, s. 65-74.

Kvât kovskaâ A. V. 1998, Âtvâžskie mogil'niki Belarusi (k. XI-XVII vv.), Vilnius.

L i n n i č e n k o I. A. 1884, Vzaimnye otnošeniâ Rusi i Polši do poloviny XIV stoletiâ, 1, Kiev.

L i s te ... 1895, Liste des associés correspondants nationaux et étrangers. Au 2 Mai 1894, „Bulletin de la Société Nationale des Antiquaries de France”, 1894, s. 16-35.

Łęg a W. 1930, Kultura Pomorza we wczesnem średniowieczu na podstawie wykopalisk, 1, Toruń.

Ł u n i e w s ki T. 1882, Cmentarzysko starożytne w Żarnówce, „Wiadomości Archeologiczne”, 4, s. 109-126.

Ma le c zyń ski K. 2010, Bolesław III Krzywousty, wyd. 2, Kraków.

M a r c i n i k J. 1959, Cmentarzysko szkieletowe z okresu wczesnośredniowiecznego znalezione w miejscowości Kościesze, pow. Puttusk, „Wiadomości Archeologiczne”, 26/1-2, s. 63-67.

M a r c z a k J. 2015, Ludwik de Fleury (1828-1909) właściciel majątku Kępa n/Biebrza (https:// www.grajewiak.pl/index.php/biogramy/548-fleury-ludwik, dostęp 6.02.2020).

M iś k i e w i c z o w a M. 1981, Mazowsze wschodnie we wczesnym średniowieczu, Warszawa.

M i śk i e w i c z ow a M. 1982, Mazowsze płockie we wczesnym średniowieczu, Płock.

M i śk i e w i c z o w a M. 1996, Wczesnośredniowieczny kompleks osadniczy w Niewiadomej $w$ województwie siedleckim, Warszawa.

M u s i a n ow i c z K. [ 1948] 1949, Kabłączki skroniowe - próba typologii i chronologii, „Światowit", 20, s. 115-232.

M u s i a n o w i c z K. [1951-1952] 1952, Mazowieckie naczynia z cylindryczną szyjka na tle stowiańskiego materiału porównawczego, „Wiadomości Archeologiczne”, 18/3-4, s. 345-384.

M u s i a n ow i c z K. 1960, Granica mazowiecko-drehowicka na Podlasiu we wczesnym średniowieczu, Materiały Wczesnośredniowieczne, 5, Warszawa, s. 187-230.

Musin A., Dzik M., w druku, Archeologia archiwalna. Materiały Cesarskiej Komisji Archeologicznej do badań nad dziedzictwem materialnym wschodniej Polski, Rzeszów.

Musin A., Medved e va M. red. 2019, Imperatorskaâ Arheologičeskâ̂ Komissiâ (1859-1917). Istoriâ pervogo gosudarstvennogo učreždeniâ rossijskoj arheologii od osnovaniâ do reformy, 1-2, wyd. 2, Sankt-Peterburg. 
Mu s in A., No s ov E. re d. 2009, Imperatorskâ̂ Arheologičeskaâ Komissiâ (1859-1917). K 150-letiû co dnâ osnovaniâ. U istokov otečestvennoj archeologii i ohrany kul'turnogo naslediâ, 1-2, Sankt-Peterburg.

Mülle r U. 2011, Hochmittelalterliche Bronzeschalen in Ostmitteleuropa, [w:] Ekskluzywne życie - dostojny pochówek. W kręgu kultury elitarnej wieków średnich, M. Rębkowski red., Wolińskie Spotkania Mediewistyczne, I, Wolin, s. 233-260.

N a d ols k i A. 1954, Studia nad uzbrojeniem polskim w X, XI i XII wieku, Acta Archaeologica Universitatis Lodziensis, 3, Łódź.

N a z a r e n ko A. V. [ 2007] 2009, Drevnââ Rus' i slavâne (istoriko-filologičeskie issledovaniâ), Drevnejšie gosudarstva Vostočnoj Evropy, Moskva.

No tice 1910, Notice sur le Comte Louis Eugène de Fleury - Associé correspondant national de la Société des Antiquaires de France - Membre correspondant de la Société archéologique et historique de la Charente - 1827-1909, „Bulletin et mémoires de la Société archéologique et historique de la Charentes", 1910, s. LXII-LXVIII.

O d o j R. 1958, Sprawozdanie z prac wykopaliskowych, przeprowadzonych w Równinie Dolnej, pow. Kętrzyn w 1956 i 1957 r., „Rocznik Olsztyński”, 1, s. 117-156.

Olczak H., Kras n odę b ski D. 2019, Wschodniosłowiańskie szkieletowe cmentarzysko kurhanowe w Uroczysku Jelonka w Puszczy Białowieskiej, [w:] Początki chrześcijaństwa na pograniczu mazowiecko-ruskim w świetle wyników badań wybranych cmentarzysk, A. Buko red., Warszawa, s. 67-72.

O lc z a k H., K r a s n o dę b s k i D. 2020, Suraż na tle osadnictwa pogranicza mazowiecko-rusko-litewskiego w okresie od XI do XVI w., [w:] Suraż - średniowieczny gród na pograniczu mazowiecko-rusko-litewskim, Warszawa, s. 469-506.

O śc ił o w s k i J . [ 2004-2005] 2006, Sieć grodowa na Wysoczyźnie Kolneńskiej we wczesnym średniowieczu. Ze studiów nad pograniczem mazowiecko-prusko-jaćwieskim, „Światowit”, $6(47) / B$, s. 81-105.

O ściłowski J. 2011, Uwarunkowania geograficzne lokalizacji grodów na północnym Mazowszu (X - pocz. XIII w.). Problematyka badań interdyscyplinarnych, „Rocznik Muzeum Mazowieckiego w Płocku”, 19, s. 7-40.

O śc iło w s k J. 2013, Wysoczyzna Kolneńska we wczesnym średniowieczu. Nowe dane do dziejów osadnictwa, „Studia Łomżyńskie”, 24, s. 99-109.

P a c u s k i K. 2019, Wschodnia granica Mazowsza w średniowieczu w świetle danych historycznych (X-XV w.), [w:] Początki chrześcijaństwa na pograniczu mazowiecko-ruskim w świetle wyników badań wybranych cmentarzysk, A. Buko red., Warszawa, s. 15-32.

$\mathrm{P}$ a vl e n k o S. 2010, Ovruc'ka serednovična pirofilitova industriâ: rezul'tati, problemi ta perspektivi doslidžennâ, [w:] Problemi davn'orus'koï ta serednovičnoï arheologiï, G.Û. İvakìn red., Arheologîa i davnâ istoriâ Ukraïni, 1, Kiïv, s. 157-166.

Pela W., Skrok Z. 1987, Wykopaliska na rubieżach Mazowsza, „Ziemia Łomżyńska”, 3, s. 119-124.

Pło c h a J. 1969, Najdawniejsze dzieje opactwa benedyktynów w Mogilnie, Wrocław.

Poklew ski T. 1961, Misy brazowe z XI, XII i XIII wieku, Acta Archaeologica Universitatis Lodziensis, 9, Łódź.

Procès-verbaux [ 1890-1891] 1892, Procès-verbaux, „Bulletin et mémoires de la Société archéologique et historique de la Charentes", s. XXV-LXXIII.

Pro to kol" "1893, Protokol" zasědaniâ I-go otděleniâ (pervobytnyâ drevnosti) v" 1 čast" dnâ, [w:] Izvěstiâ IX arheologičeskago s"ězda v"g. Vil'ně, 12, s. 3-5. 
Protokoly 1897a, Protokoly, [w:] Trudy devâtago arheologičeskago s"ězda v"Vil’ně 1893, P.S. Uvarova, S.S. Sluckij red., II, Moskva, s. 1-126.

Protokoly 1897b, Protokoly zasědanij VIII Arheologičeskago S”ězda, [w:] Trudy vos'mago arheologičeskago s"ězda v" Moskvě 1890, P.S. Uvarova red., IV, Moskva, s. 49-204.

R a d zi ko w ska M. 2019, Birytualizm na cmentarzysku „Tureckie Mogity” w Czekanowie zjawisko jednostkowe czy świadectwo przeżywającej się tradycji?, [w:] Początki chrześcijaństwa na pograniczu mazowiecko-ruskim w świetle wyników badań wybranych cmentarzysk, A. Buko red., Warszawa, s. 129-139.

R a m o to w ski J. 2013, Ludwik de Fleury - pasjonat z Kępy Giełczyńskiej, „Studia Łomżyńskie", 24, s. 281-294.

$\mathrm{R}$ a u h t L. 1971, Wczesnośredniowieczne cmentarzyska w obudowie kamiennej na Mazowszu i Podlasiu, Materiały Starożytne i Wczesnośredniowieczne, I, Warszawa, s. 435-656.

$\mathrm{R}$ a u h t L . 1973, Nowe odkrycia grobów ciałopalnych na cmentarzyskach wczesnośredniowiecznych w obudowach kamiennych na Mazowszu i Podlasiu, „Wiadomości Archeologiczne", 38/2, s. 361-364.

R a u h u L., D ł u g o p ols ka L. 1971, Wczesnośredniowieczne cmentarzysko szkieletowe w obudowie kamiennej w Pokrzywnicy Wielkiej, pow. Nidzica, „Wiadomości Archeologiczne", 36/3, s. 292-353.

R a u h u L L., D łu g o p ols ka L. 1972, Wczesnośredniowieczne cmentarzysko szkieletowe w obudowie kamiennej w Łaczynie Starym, pow. Przasnysz, „Wiadomości Archeologiczne”, 37/3, s. 320-393.

R a u hut L., Dług o p olska L. 1973, Wczesnośredniowieczne cmentarzysko szkieletowe w obudowie kamiennej w Tańsku-Przedborach, pow. Przasnysz, „Wiadomości Archeologiczne", 38/3-4, s. 383-441.

Rauhut L., Długopolska L. 1974, Cmentarzysko z XII-XIII w. wobudowie kamiennej w Rybałtach, pow. Siemiatycze, „Wiadomości Archeologiczne”, 39/3, s. 339-372.

Rut k ow ski L. [ 1906] 1907, Cmentarzyska rzędowe w Rostkowie, Strzeszewie, Wierzbicy, Żachowie, Blichowie i Rogowie badane przez ś. p. Franciszka Tarczyńskiego, „Światowit”, 7, s. 39-43.

S a w i c k i J. 2015, Kultura materialna $w$ świetle znalezisk $z$ grobów na cmentarzu Salwatora we Wrocławiu, [w:] Cmentarz Salwatora. Pierwsza nekropolia wrocławskich protestantów, K. Wachowski red., Wratislavia Antiqua, 21, Wrocław, s. 59-137.

S a w i ck i T. 2016, Przedmioty żelazne, [w:] Bodzia. Elitarny cmentarz z początków państwa polskiego, A. Buko red., Warszawa.

Schätze... 2011, Schätze des Mittelalters. Schmuck aus dem Staatlichen Archäologischen Museum Warschau. Katalog zur Ausstellung, W. Brzeziński red., Bönen.

S i a n k o P. 2019, Granica mazowiecko-litewska do 1569 roku. Kształtowanie się, rola społeczna, maszynopis pracy doktorskiej przechowywany w archiwum Instytutu Historii i Nauk Politycznych Uniwersytetu w Białymstoku, Białystok.

Sidorovič V.M., Râbceva S.S., Plavinskij N.A. 2015, Degtânskij klad serediny XI veka: sostav i kontekst, „Stratum Plus”, 6, s. 143-180.

S m or o d skij A.P. 1893, Devâtyj arheologičeskij s"ezd v"Vil’ně i ego značenie dlâ Minskoj gubernii, Minsk.

S ol e ck i R. 2018, Cmentarzysko wilanowskie w okresie od średniowiecza po nowożytność, Warszawa.

Solon J., Borzykowski J., Bidłasik M., Richling A., Badora K., Balon J., Brzezińska-Wójcik T., Chabudziński Ł., Dobrowol- 
ski R., Grzegorczyk I., Jodłowski M., Kistowski M., Kot R., Krąż P., Lechnio J., Macias A., Majchrowska A., Malinowska E., Migoń P., Myga-Piątek U., Nita J., Papińska E., Rodzik J., Strzyż M., Terpiłowski S., Ziaja W. 2018, Physico-geographical mesoregions of Poland: verification and adjustment of boundaries on the basis of contemporary spatial data, „Geographia Polonica”, 91/2, s. 143-170.

S olov' i e v S.M. 1988, Sočineniâ v 18 tomah, 1, Istoriâ Rossii s drevnejših vremën, 1-2, Moskva.

S p i c y n A . 1925, Litovskiâ drevnosti, „Tauta ir Žodis”, 3, s. 112-171.

S t o r o ž e v V. N. 1894, IX arheologičeskij s"ezd vg. Vil’no, Sankt-Peterburg.

S z c z e r b a A. 2010, Rola Carskiej Komisji Archeologicznej w ochronie zabytków archeologicznych na obszarze Imperium Rosyjskiego, „Analecta. Studia i Materiały z Dziejów Nauki”, 19/1-2, s. 7-21.

S z c z e r b a A. 2012, Problem ochrony zabytków archeologicznych na ziemiach dawnej Rzeczypospolitej pod panowaniem rosyjskim, Monografie Instytutu Archeologii Uniwersytetu Łódzkiego, IX, Łódź.

S z e w c z u k U. 2004, Misa brązowa z Blichowa w woj. mazowieckim, [w:] Hereditatem cognoscere. Studia i szkice dedykowane Profesor Marii Miśkiewicz, Z. Kobyliński red., Warszawa, s. $225-228$.

Tabella 1827, Tabella Miast, Wsi, Osad Królestwa Polskiego z wyrażeniem ich położenia i ludności [...], II, Warszawa.

Ta r c z y ń s k i F. 1900, Groby rzędowe kamienne w pow. Płockim, „Światowit”, 2, s. 19-27.

Ta r c zy ń s k i F. 1901, Groby rzędowe kamienne w pow. Płockim, „Światowit”, 3, s. 30-32.

Trigge r B. G. 2007, A history of archaeological thought, wyd. 2, Cambridge.

Trzciński M., Skow ron J. 2006, Kotówek, st. 1, gm. Jedwabne, Informator Archeologiczny. Badania 1997, Warszawa, s. 197.

Uvarova P.S., B or o z d in I. N. red. 1915, Imperatorskoe Moskovskoe Arheologičeskoe Obŝestvo v pervoe 50-letie ego suŝestvovaniâ (1864-1914), 2, Moskva.

[Virchow R.] 1875, Sitzung vom 14. Mai 1875 - R. Virchow berichtet, unter Vorlegung der wichtigsten Fundstücke, über verschiedene deutsche Alterthümersammlungen, sowie neue Ausgrabungen bei Priment, Zahorowo und Wollstein, „Zeitschrift für Ethnologie”, 7, s. 95-112.

Volte r È. 1889, Arheologičeskie kollekcii častnyh lic v severo-zapadnom krae, „Vilenskij Vestnik", 269 (13 grudnia), s. 2-3.

Wa dy l S. 2019, Narzędzia i przedmioty codziennego użytku, [w:], Ciepte. Elitarna nekropola wczesnośredniowieczna na Pomorzu Wschodnim, S. Wadyl red., Gdańsk, s. 187-202.

Wi e czorek-Kańczuta K., S z a j t J. 2018, Noże, pochewki $i$ okucia pochewek na noże, [w:] Rytm rozwoju miasta na kulturowym pograniczu. Studium strefy placu Nowy Targ we Wrocławiu, 1, J. Piekalski, K. Wachowski red., Wratislavia Antiqua, 23, s. 296-322.

Wło d a r ski B . [ 1958-1959] 1959, Problem jaćwiński w stosunkach polsko-ruskich, „Zapiski Historyczne", 24/2-3, s. 7-36.

Włodarski B. 1966, Ruś w planach politycznych Bolesława Krzywoustego (1102-1238), „Zeszyty Naukowe Uniwersytetu Mikołaja Kopernika w Toruniu. Nauki Humanistyczno-Społeczne", 20, Historia, II, s. 37-57.

Woj ci e ch ow ski T. 1970, Szkice historyczne XI wieku, wyd. 4, Warszawa.

Wrze s iń ski J. 2000, Noże żelazne w grobach na wczesnośredniowiecznym cmentarzysku w Dziekanowicach, „Studia Lednickie”, 6, s. 91-124. 
Z a j k o ŭ skì È. 2018, Slavânskiâ pahavanni z draŭlânymi vëdramì arèal raspaŭsûdžannâ, hranalogiâ, vytoki tradycyì, semantyka, „Materìali ì doslìdžennâ z arheologiï Prikarpattâ ì Volinì", 22, s. 135-155.

Z a šéda nie 1893, Zasědanie IX Arheologičeskago s"ězda v"Vil’ně. Zasědanie I-go otděleniâ (pervobytnyâ drevnosti) 12 avgusta, [w:] Arheologičeskiâ Izvěstiâ i Zamětki izdavaemyâ Imperatorskim" Moskovskim" arheologičeskim" obŝesvom", A.V. Orěšnikov red., I, Moskva, s. 365-368.

Z a w a d z ka - A n t o s i k B. 1973, Wczesnośredniowieczne cmentarzysko w obudowie kamiennej w Grzebsku, pow. Mława, „Wiadomości Archeologiczne”, 38/3-4, s. 461-492.

Zj a zd 1893, Zjazd archeologiczny w Wilnie, „Gazeta Warszawska”, 120 (217), s. [3-4].

Ży tyń ski L. 1893, IX. Zjazd archeologiczny w Wilnie, „Wiadomości Numizmatyczno-Archeologiczne", 5/1 (15), szp. 123-126.

\section{MICHAŁ DZIK}

\section{LOUIS DE FLEURY AND THE EARLY MEDIEVAL CEMETERY SITES WITH CIST GRAVES IN THE KOLNO UPLAND}

\section{Sum mary}

In 1892, Louis de Fleury carried out amateur archaeological excavations at some early medieval cemeteries with graves furnished with stone constructions in the localities of Kokoszki, Rostki Małe (now Kotówek) and Ruś in the Łomża district, Podlaskie province (voivodship). He presented a report from this work to the Imperial Archaeological Commission in Petersburg (Figs 1-4). Information about his work was not circulated widely in the archaeological literature, hence his results had little impact on studies of burial customs and settlement change in this borderland between the Polish and Rus' states and the land of the Prussian tribes. The three localities have been all but destroyed in the 130 years since de Fleury's investigations. Their location is known, precisely in the case of Kokoszki and Rostki Małe (Kotówek) and approximately for Ruś (Figs 5-10).

De Fleury excavated a total of 19 graves, all but one of which were graves of stone structure (Table 1). The bulk of these were oblong or rectangular in shape. In all instances there was a layer of stones about $20 \mathrm{~cm}$ thick, set within a stone enclosure. Skeletons were found directly under these stone coverings, most often on the level of the bottom of the stone walls of the graves. Most of these 18 graves were of type I (pitless) with just three representing type II.1 (shallow pits; for the typology: Dzik 2015, II, pp. 39-46) and in one case probably type III (pit grave without a stone covering or enclosure).

Burned bones were found in one grave (Ruś, grave no. 9) and a total of 20 inhumation burials were observed in 17 graves (Table 2). In the case of five individuals, the preservation of the remains was fairly good, meaning that at least the skull and the limb bones were present. In the remaining $75 \%$ of the burials only singular pieces of human bone were recovered. Wherever the arrangement could be observed, the skeleton was found laid out flat on the back. The orientation was noted in 11 cases: for the most part the head pointing west deviating south, in at least three cases pointing east with a northward deviation.

Grave goods were found in 17 of the 19 graves. They are known only from illustrations and very modest descriptions, but even this naturally limited information is sufficient for comparative analysis with artifacts coming from neighboring regions. 
Elements of dress and personal adornments were noted in at least seven burials (32\%). Silver or silver-plated temple rings, 12 in number, with an outer diameter between 1.8 and $2.5 \mathrm{~mm}$, came from grave 2 in Ruś (Fig. $3 n-y$ ); they represent type III according to K. Musianowicz ([1948] 1949). According to L. Rauhut (1971, p. 473), ornaments of the same kind from the Masovia region, which were "small" (outer diameter not exceeding about $20 \mathrm{~mm}$ ), should be dated to the $11^{\text {th }}$ and the first 20 years of the $12^{\text {th }} \mathrm{c}$., while the "middle-sized" examples (outer diameter reaching about $50 \mathrm{~mm}$ ) belonged to the end of the $11^{\text {th }}$ through the third quarter of the $12^{\text {th }} \mathrm{c}$. These same ornaments originating from the area between the eastern lower Bug and upper Narew rivers, typologically classified as subtype III.1 (outer diameter less than $20 \mathrm{~mm}$ ), were found in features dated to the last three dozen years of the $11^{\text {th }} \mathrm{c}$. through the first quarter of the $12^{\text {th }}$ c.; examples of subtype III.2 (outer diameter from 20 to $27 \mathrm{~mm}$ ) came from features that covered a longer timespan, between the last three dozen years of the $11^{\text {th }} \mathrm{c}$. and the end of the $13^{\text {th }}$ c. (Dzik 2015, I, p. 165 and II, pp. 9-12).

A necklace of 10 beads was found in grave 2 from the locality of Ruś. Two of these beads were of metal, three of stone and five of glass (Table 3; Fig. 3d-m). A knobbed bead of silver, probably with granulated decoration, is common among finds from Poland (Kóčka-Krenz 1993, map 41) and less frequent in Belarus and Ukraine. The chronology of these beads has yet to be studied in detail, but the present state of research justifies the view that they were typical of the period from the last quarter of the $11^{\text {th }}$ to the first half of the $12^{\text {th }} \mathrm{c}$., with a sporadic occurrence still in the second half of the latter century. The second of the metal beads was globular and decorated with filigree (Fig. $3 \mathrm{~m}$ ). Based on the drawing and description, the body of the bead can be said to be of wire rather than sheet metal, this in view of the presence of rings around the threading holes and loose distribution of the granulation (see Dzik 2015, I, p. 190, description of beads of subgroup I.2). The stone beads from this grave are of a faceted type; the pale purple color of the material suggests either fluorite or amethyst. According to Rauhut, similar beads from Masovian cemeteries are dated chiefly to the first half of the $12^{\text {th }} \mathrm{c}$., occurring sporadically in burials of both earlier and later date, from the last quarter of the $11^{\text {th }} \mathrm{c}$. and from the third quarter of the $12^{\text {th }}$ c. respectively (Rauhut 1971, pp. 466ff.). Finally, the five biconical glass beads represent a class of beads with numerous parallels in Masovia and the region between the Bug and Narew rivers (Kordala 2006, pp. 161-163; Dzik 2015, I, pp. 178-187). Three of these are most probably of yellow color, while two are purple. Beads of the latter color, from grave contexts located in the interfluve region described above, are usually part of assemblages dated to the second quarter of the $12^{\text {th }}$ through the mid- $13^{\text {th }}$ centuries (Dzik 2015, II, 17, Table 5).

Rings were discovered in three of the graves, one each per cemetery investigated by de Fleury (Table 3; Figs 2j; 3c). All of them were described as objects of silver-wire, plaited, open-ended. A buckle came from grave 6 (?) at Ruś (Fig. 4l). Judging by the drawing, the proportions of the item and the presumed copper alloy from which it was made, as well as known buckle types, it belongs to the class of rectangular, two-element examples that are longer than wider.

The only weapon found by de Fleury is a spearhead from grave 1 in Kotówek (Rostki Małe; Fig. 21).The shape appears to correspond to type IV according to A. Nadolski (1954, p. 54) and type IV in the classification of A. Kirpichnikov (Kirpičnikov 1966, pp. 14-15, Fig. 1), dated in both cases to the $11^{\text {th }}-12^{\text {th }}$ centuries.

Artifacts classified as tools were found in nine or ten burials ( $41 \%$ or $45 \%$ of all burials), perhaps even 13 if nails are considered in this category (59\%). Knives were found in five or six burials, two together in the case of burial 7b at Ruś. The shape of four of the knives can be determined from preserved drawings (Figs $2 \mathrm{k} ; 4 \mathrm{~h}, \mathrm{~m}, \mathrm{q}$ ). The piece from grave 1 in Kotówek (Rostki Małe), considered as large, was distinguished by a straight or slightly arched spine of the blade, widened at the tip (Fig. 2k). Knives of this form, classified as type VI, variant a, in J. Wrzesiński's 
typology (2000, pp. 99-100), are seldom encountered. Analogous finds provide a date from the mid- $11^{\text {th }}$ to the third quarter of the $12^{\text {th }} \mathrm{c}$.

At least two of the knives from the graves in Ruś were deposited sheathed. Sheath fittings are frequent in the early medieval cemeteries of Masovia and today's Podlasie, especially in northern Masovia (Kordala 2006, pp. 178-182). However, iron fittings of the kind discovered in grave 6c in Ruś (Fig. 4i) are very rare in graves from the $11^{\text {th }}-13^{\text {th }}$ centuries. In the nearest vicinity, knives of this kind have been recorded among others at the cemetery site in Rybałty, Siemiatycze district (Rauhut, Długopolska 1974, p. 353), and Święck-Strumiany (D. Jaskanis 2008, p. 374).

The double-sided flint striker from burial $6 \mathrm{c}$, rectangular in shape, with semicircular sides of the opening, is not without parallel (Fig. 4g), but none of the analogous finds known to the author has the rectangular notches on the shorter sides displayed by the specimen from Ruś. The same burial also yielded spring shears (Fig. 4f). There are only two analogous finds, both from northern Masovia. The known and well dated parallels suggest that objects of this kind were deposited in burial contexts from the $11^{\text {th }}$ to the mid- $12^{\text {th }} \mathrm{c}$. AD. Iron nails were discovered in either seven or eight ( $32 \%$ or $36 \%$ of the total) burials (Figs $2 a-d, n, o ; 3 a, b ; 4 n-p)$ : two nails together in at least four graves and in one instance six nails (Table 3 ). Traces of wood were observed in three of the graves with nails (Table 3 ).

Remains of three vessels, deposited whole in all likelihood, were found in two graves. Iron fittings of a stave bucket were recorded in grave 1 from Kotówek (Fig. 2e-i). In turn, remains of two bronze bowls came from grave $6 \mathrm{c}$ in Ruś. The larger one of the two was illustrated: it was about $5 \mathrm{~cm}$ high, the diameter 18-20 cm (Fig. 4r), undecorated, which classifies it as Type VI according to T. Poklewski (1961, p. 25). Examples of this type are dated to the $10^{\text {th }}$ (second half rather), through the $12^{\text {th }}$, with just a few from the $13^{\text {th }}$ c. (Müller 2011, p. 252).

Clay vessel sherds are the most numerous group, recorded in either 12 or 13 graves $(65 \%$ or $68 \%$ of all the burials). According to de Fleury, finds from the stronghold in Wizna were analogous (Fig. 11). Near to nothing is known about the positioning of these vessels within the burials, their number or their size. Had any of them been complete, de Fleury would have surely noted the fact.

The dating of the cemeteries is based currently on the form of the graves and the artifacts found in the burials. Stone-structure graves of type I in Dzik's classification (no pit; stone casing and covering), as well as type II.1 (shallow pits, stone casing and covering), in the interfluve region between the Bug and upper Narew rivers, are dated from the last third or quarter of the $11^{\text {th }}$ c. to about the middle of the $14^{\text {th }}$ c. (Dzik 2015, II, pp. 179, 199-200). Graves of type I predominated from the end of the $12^{\text {th }} \mathrm{c}$. (about $90 \%$ of the features). Graves of this kind from Masovia are dated from the mid- $11^{\text {th }}$ to the $13^{\text {th }}$ c. (Rauhut 1971, pp. 465-469; Kordala 2003). Structures of these two types correspond to variant IIa and some features of variant IIb in Rauhut's classification (1971, p. 456). Graves of this form were dated by Rauhut to a period from the $11^{\text {th }} / 12^{\text {th }}$ to the mid- $12^{\text {th }} \mathrm{c}$.

Parallels for the grave with a cremation burial from Rus can be found on the upper stretch of the Orzyc river, dated to the second half of the $11^{\text {th }}$ through the $12^{\text {th }} / 13^{\text {th }} \mathrm{c}$. (Rauhut 1973 , p. 363). In the territory discussed here cremation burials were present at most of the investigated cemeteries with the stone-structure graves. The practice of cremating human remains disappeared in this region most probably in the $12^{\text {th }}$ c. (Dzik 2015, II, pp. 74-89, 195). Based on parallels the grave from Rus should be dated to the second half of the $11^{\text {th }}-12^{\text {th }}$ centuries.

Most of the finds that can help to make the dating of the Ruś graves more precise were found in graves 2 and 6 . The rich set of ornaments from the former of the graves, including the temple rings of type III.1, date the burial between the middle of the $11^{\text {th }}$ and the first quarter of the $12^{\text {th }} \mathrm{c}$. Graves 3 and 4, directly adjoining grave 2, present a similar chronology. Burial 6c was 
made between the end of the $11^{\text {th }}$ and the mid-12 $12^{\text {th }} \mathrm{c}$., a date suggested by the parallels for the bronze bowls from the stone-structure graves and also from Czersk. The dating of burials with shears among the grave goods appears to stand in confirmation. It is justified to attribute the other burials from grave 6, as well as those from the neighboring grave 5, to the same period. At the cemetery in Kotówek (Rostki Małe), the grave goods from grave 1 - the spearhead, knife and stave bucket - gave good grounds for dating it to between the mid- $11^{\text {th }}$ and mid- $12^{\text {th }} \mathrm{c}$. For the other burials, the chronological premises are weaker. The eastern orientation of some of the burials, chiefly male, endures in the $12^{\text {th }} \mathrm{c}$., being particularly common in the first quarter or first half of the century (Kordala 2006, p. 120; Dzik 2015, II, p. 181). The large percentage of graves containing nails ( $40 \%$ in total from three sites) could be considered as a chronological indicator. In the Drohiczyn Upland, where there is a relatively large share of graves containing nails, similar values were noted only for graves representing subphases B1 and B2 in the local typology (last third or quarter of the $11^{\text {th }}$-fourth quarter of the $12^{\text {th }} \mathrm{c}$.). In the following decades, the share of graves with nails falls below 10\% (Dzik 2015, II, p. 156). In the same region, burial customs attested by the presence of lumps of charcoal in the graves of two inhumation burials at Kotówek (Rostki Małe) and two in Ruś, were common in the $12^{\text {th }} \mathrm{c}$. and were present still in the first half of the $13^{\text {th }}$ c. (Dzik 2015, II, p. 131).

Based on the evidence from the cemeteries at Kotówek (Rostki Małe) and Ruś, these burial grounds were established between the mid- $11^{\text {th }} \mathrm{c}$. and the first quarter of the $12^{\text {th }} \mathrm{c}$., but taking into consideration grave structure and dating of analogous forms from the much better investigated cemeteries on the upper Orzyc river and in the Drohiczyn Upland, they could not have been formed before the last third of the $11^{\text {th }} \mathrm{c}$. and in the first quarter of the next century at the latest. The breaking off point for the functioning of these burial grounds appears to fall between the middle and the end of the $12^{\text {th }} \mathrm{c}$., but since the investigations were very limited, it is not to be excluded that burials actually continued for a longer time.

A current map of cemeteries from the $11^{\text {th }}-12^{\text {th }}$ centuries in the Kolno Upland, most of them investigated thanks to the amateur excavations of de Fleury (Fig. 12), reveals no older forms of graves that could have given rise to the early medieval tombs of stone construction. This apparent absence of a local burial tradition suggests an interpretation according to which they reflect either migration or dislocation of a certain population from another region. Searching for the origin of the people who arrived in the region at this time, one should look first at burial customs as the most lasting element of human spirituality and only afterwards at the material culture.

Considering the type of grave structure, the tentative migrants could have come from northern Masovia or the Drohiczyn settlement cluster. ${ }^{1}$ The stone-structure graves from the Kolno Upland are paralleled in terms of their form by graves from the region on the upper Orzyc where they are dated by Rauhut to the $11^{\text {th }} / 12^{\text {th }} \mathrm{c}$., and from the Drohiczyn cluster, dated there to the last third or quarter of the $11^{\text {th }} \mathrm{c}$. There exist similarities between the two regions in terms of burial customs, like the way stones are used in the stone-structure or customs that are reflected in a frequent presence of charcoal in the graves. Differences appear to concern two aspects: wooden coffins (or other structures) nailed together with iron nails, and the manner of deposition of pottery vessels in the graves.

Northern Masovia appears to have avoided the use of nails in graves: just two instances of graves with stone constructions (Kordala 2006, p. 191). It is most probably not because of a lack of coffins. Wherever the conditions were conducive to the preservation of wooden remains, traces

${ }^{1}$ Settlement cluster on the eastern stretch of the lower Bug, limited by the Nurzec on the north and the watershed of the left tributaries of the Bug and Krzyna on the south. The eastern boundary runs between the Nurczyk and Pulwa tributaries, and in the west it reaches the Cetynia river and its tributaries (see Miśkiewiczowa 1981, pp. 62-63; Dzik 2015, II, pp. 173-174). 
of coffins were quite frequent and they were mostly pegged together with wooden pegs (Dzik 2006, pp. 61-63). In turn, more than a 100 graves in the Drohiczyn cluster contained nails, of which there were altogether 500 among the finds. In this region, the use of nails in this context was frequent through the end of the $12^{\text {th }}$ C. (Dzik 2015, I, pp. 239-244; II, pp. 153-156, 184).

It was common practice in northern Masovia to deposit clay vessels in the burials (Kordala 2006, pp. 194-201). In the Drohiczyn cluster, none of the graves from the $11^{\text {th }}$ or $12^{\text {th }} \mathrm{c}$. contained complete vessels, but it was common to have the broken sherds of vessels that had been smashed elsewhere collected and deposited in the graves (Dzik 2015, I, pp. 261-264).

In these respects, the customs observed in the cemeteries with the stone-structure graves from the Kolno Upland correspond to those noted in the Drohiczyn cluster. More similarities exist: no deep grave pits with pavements of the kind known from the Old Masovia region; boulders of distinctively large size by the feet (Ruś graves 2 and 10 like in the Drohiczyn Upland; Dzik 2015, II, p. 41). A triple grave in Ruś (no. 6) is without parallel in this respect in northern Masovia but corresponds to graves of similar form and number of burials in the Drohiczyn cluster, e.g. the cemeteries in Aleksandrowo, Siemiatycze district (Dzik 2015, II, Fig. 47). If the Ruś burial $6 \mathrm{c}$ has been recognized correctly as a bi-ritual burial, then this custom finds parallels in the Drohiczyn cluster, but not in Masovia.

Taking into consideration these arguments, it appears justified to assume that the population using the cemeteries in question in the Kolno Upland could have originated from the Drohiczyn cluster, possibly the Bielsko Plain, which is known for a small cluster of burial grounds with features resembling the graves from the Drohiczyn cluster (Dzik 2015, II, pp. 179-182, Figs 57, 58). The only grave furnishings not paralleled in the Drohiczyn cluster are the bronze bowls which are known from Ruś and Pieńki-Okopne. The bowls as well as the ornaments (eye bead from Ruś, temple ring with a 5-cm diameter from Pieńki-Okopne) are proof of strong cultural contacts with Masovia. However, the difference lies not in the custom, but in the form of an object or the material of which it was made. The graves in the Drohiczyn cluster were furnished with wooden vessels, beads and temple rings. The resettled population, particularly in the first generation, tended to preserve old burial customs, even of certain elements were undergoing change presumably among the social elite for the most part, owing to intensive contacts with Masovia.

The hypothesis adopted in most historical studies is of a permanent border between Poland and Rus' established in the northern part in 1041-1047, in effect of the conflict with Mieclaw (e.g. Bieniak 2010, p. 173; Pacuski 2019, p. 18). The situation was stable until at least 1145 when Kiev Great Prince Vsevolod Olegovich allegedly received Wizna in return for siding with Władysław II against the junior princes, although it is not clear that this had indeed taken place (PSRL 1908, col. 318; see Kowalczyk-Heyman 2013, pp. 231-234). The most recent analysis of archaeological sources has overturned this idea (e.g. Dzik 2015, II, pp. 187-194, 196-199; Olczak, Krasnodębski 2020 , pp. 482-495). It seems that political influence in the northern borderland was not as permanent as assumed hitherto, while the actual division was, at least for a time, different from that reconstructed on the grounds of later sources.

Written sources from the $11^{\text {th }}-12^{\text {th }}$ centuries seldom mention the Kolno Upland. Wizna is the only local placename that appears. Archaeological sources indicate settlement in the district from the Masovian direction at least from the end of the $9^{\text {th }} \mathrm{C}$. and a permanent incorporation into the Piast realm from the $11^{\text {th }}$ c. (Ościłowski [2004-2005] 2006, pp. 98-99; Kowalczyk-Heyman 2013 , pp. 201-203, 326). In light of this, it is justified to presume that a new population from the southeast arrived in this long-settled land in the second half of the $11^{\text {th }}$ or at the beginning of the $12^{\text {th }} \mathrm{c}$. This was most probably connected with the political situation on the frontiers of the Piast realm, hence it is worth recalling events, known from the written sources, that could have 
affected the understanding and proper interpretation of the situation observed on the grounds of the archaeological sources.

The Tale of Bygone Years, or the Rus' Primary Chronicle as it is also known in English, brings a description of military activities developing around the Kolno Upland in the 1030s. In 1038, Yaroslav the Wise mounted an expedition against the Yotvingians and in 1040 against Lithuania (PSRL 1926-1928, col. 153). In 1041-1047, the Rus' prince joined Kazimierz I the Restorer in putting down Mieclaw and ultimately subordinating Masovia again to Piast rule (PSRL 1926-1928, cols 153, 155; PSRL 1908, cols 141, 143). It was undoubtedly a time when zones of influence were being shaped in the borderland between the Rurikids and the Piasts. Political change could have occurred the next time 20 years later, in 1069-1077. In 1069, Bolesław effectively retook Kiev for his relative Izyaslav who had been overthrown the year before by Vseslav (PSRL 1926-1928, cols 173-174). Whether any territories changed hands at this time is not known; only the so-called Cherven cities may have passed into other hands (Delestowicz 2016, pp. 117-118, 326-334 with more references on the identification of these strongholds, see Jusupović 2017). Izyaslav lost the throne again in 1073 and again asked Bolesław for help, but with less success. The borderland could not have been quiet, however, considering that a peace had to be concluded between Bolesław and Svyatoslav about $1074 .{ }^{2}$ Bolesław exiled Izyaslav and confirmed Svyatoslav on the throne in Kiev, and the latter assisted him in the war against the Czechs (PSRL 1926-1928, cols 199, 247). Again we are not aware of any territorial changes. Svyatoslav died in 1076 leaving the throne to his brother Vsevolod. In this situation Bolesław once again helped Izyaslav to regain the throne in Kiev (PSRL 1926-1928, cols 183, 199; PSRL 1908, cols 173, 190). Researchers have considered the possibility of a political transformation, but only with regard to the so-called Cherven cities (Grudziński 2010, p. 46).

The next occasion for political change in this borderland occurred in the first years of the $12^{\text {th }}$ c., in early June 1102 when Władysław Herman passed. His sons, Zbigniew and Bolesław, vied for position at home and abroad, and Bolesław allied himself with the Kiev Great Prince Svyatopelk Izyaslavovich, marrying the latter's daughter Zbyslava who was sent to Poland in November 1102 (PSRL 1926-1928, col. 276; see Jasiński 1992, pp. 188-190). Nothing in the sources indicates any kind of mutual military aid in the first years following the alliance until 1106 when Rus' reinforcements appeared by the side of Bolesław in the second phase of the war with

${ }^{2}$ It is pertinent to refer the following excerpt from Volodymyr Monomakh's Instructions to the times discussed here. The fragment speaks of Volodymyr being sent by Svyatoslav and Vsevolod to Brest, the "conflagration site", where he was supposed to guard the forts, and after Easter to Vladimir and Sutiejsk, where he was to make piece with the Lekhites (PSRL 1926-1928, col. 247). These events are dated to the autumn and winter of 1073/1074 (so, e.g., Linničenko 1884, pp. 116-117; recently Delestowicz 2016, pp. 182-188 with further references), alternately the same seasons of the year but in $1074 / 1075$.

It is generally accepted in the literature on the subject that Brest was burned by the Polish, a fact questioned only by T. Wojciechowski (1970, pp. 172-173, note 32). The context is interesting in this case when interpreting this fragment of the Instructions: it is said that Vladimir was accompanied in his peregrinations to Smolensk by Stavek Skordatych, who later went with Izyaslav to Brest - undoubtedly the period of Izyaslav's exile from Kiev and his march west (see Kučkin 1971, p. 31). Two verses further on Vladimir is said to have marched on Brest, which he "burned down". It looks like there is a link between the burning of Brest and Izyaslav's earlier stay there with his warriors, Stavek among them. Thus, Brest could have been burned as a result of some unknown action by Izyaslav. Regardless of who was responsible for the burning of Brest, the situation in this part of the borderland was uneasy. In 1097 and 1101, the stronghold was once again the site of confrontation between the Rus' princes, attesting to continuous political tension in the region (PSRL 1926-1928, cols 271, 275; PSRL 1908 , cols 246,250 ). 
Zbigniew (Gall 1952, II, 38; see Włodarski 1966, pp. 43-44). But before the reinforcements came, shortly after the war had started, Zbigniew appeared at the court of Svyatopelk (Gall 1952, II, 37; PSRL 1926-1928, col. 281) and must have negotiated his support if he was able to terminate a war that he had lost thanks to the mediation of Svyatopelk's son Yaroslav, Prince of Vladimir; in effect, he kept his hold on Masovia (Gall 1952, II, 38; Maleczyński 2010, pp. 72-73). There are at least two reasons why these events are surprising: first, that Zbigniew found help where he did in view of the earlier alliance between Svyatoslav and Bolesław, and second, that he found favor with Svyatopelk despite the latter sending Bolesław military aid. It is justified to assume that Zbigniew had already made an alliance with Svyatoslav and his son, and only the conditions of this alliance are an open question. For the Kiev prince the alliance with Bolesław allowed him to keep the Rostislaviches in check (Włodarski 1966, pp. 41-42). There are no sources to determine the benefits that he saw in a friendly neutrality toward Zbigniew, not to mention diplomatic support, which is confirmed for 1106 but could date back to 1102. It is possible that the Principality of Vladimir gained some territorial advantages at this time.

In the context of this hypothesis, one should consider the source information for the years 1097-1100. Svyatopelk and Władysław I Herman met at Brest (PSRL 1926-1928, col. 269; Powieść..., 2005 [Tale], p. 239). The choice of this fort for this meeting, the way in which Brest is mentioned in this period (PSRL 1926-1928, cols. 269, 271), and ultimately, the information that the Lekhites camped on the banks of the River Bug during the negotiations, suggest that Brest was a Rus' border stronghold and that the opposite bank of the river was in Polish hands (see Maleczyński 2010, note 79). This strengthens the hypothesis that the Drohiczyn land passed into the hands of the Rus' princes only after these events.

The events described above and the political instability in the years 1031-1047, 1069-1077 and at the turn of the $11^{\text {th }} \mathrm{c}$. could have instigated population movement on the Polish-Rus' borderland. Safety could have been a reason in theory, with the population seeking to remain subjects of a given ruler in the face of a shifting border. The shift could have also been caused and this is more probable - by a forced resettlement of the population from one region to another, also in connection with political changes. Resettling prisoners of war in this context does not seem very likely, primarily because of the proximity of the ultimate region to the region of origin (which could have fomented escapes), but also taking into account the high material status of those buried in the earliest of the excavated graves.

A few years ago it was proposed to link the stone-structure graves from the Drohiczyn cluster and the Bielsko Plain with the introduction of Christianization from the west, most probably in the reign of Bolesław the Generous and Władysław Herman (Dzik 2015, II, pp. 183-194; Dzik 2019, pp. 107-112). Consequently, the emergence of analogous graves in the Kolno Upland could be connected to the reigns of these two rulers, extending through the time of the co-regency of Zbigniew and Bolesław Wrymouth.

Regardless of whether or not this population migration was directly related to the political subordination of the Drohiczyn cluster, it favored a strengthening of the defensive potential of the northeastern frontier of Masovia. The action was advisable from the point of view of the Piast princes, because of the vicinity of the Prussians, but also of the people of Rus', who were becoming entrenched in the nearby Grodno region (see Kowalczyk-Heyman 2013, pp. 99, 206; Nazarenko [2007] 2009, p. 139).

Finally, the chronology of settlements in the eastern part of the Kolno Upland, that is, the part with the cemeteries of graves with stone constructions, should be noted. The stronghold in Wizna, which was dated archaeologically in the first reports to the $12^{\text {th }} \mathrm{c}$., but which could have been established already in the second half of the $11^{\text {th }} \mathrm{c}$., probably played the most important role here (Kowalczyk-Heyman 2013, p. 234). Two burial grounds with stone-structure graves 
were discovered very close to the strongholds at Pieńki-Okopne and Sambory (Ruś). These two strongholds have not been investigated extensively, but they can be dated to the $12^{\text {th }} \mathrm{c}$. based on current results (Kowalczyk-Heyman 2013, pp. 160-162, remarks on these results and further references).

In light of the dating of the cemeteries and the strongholds in their neighborhood, it is possible to suggest that the establishment of strongholds defending northeastern Masovia from Prussian and Rus' territories, at least in Sambory (Ruś) and Pieńki-Okopne, could have been associated with the settling in this region of the people who buried their dead in the cemeteries with graves characterized by stone structures.

Translated by Iwona Zych 